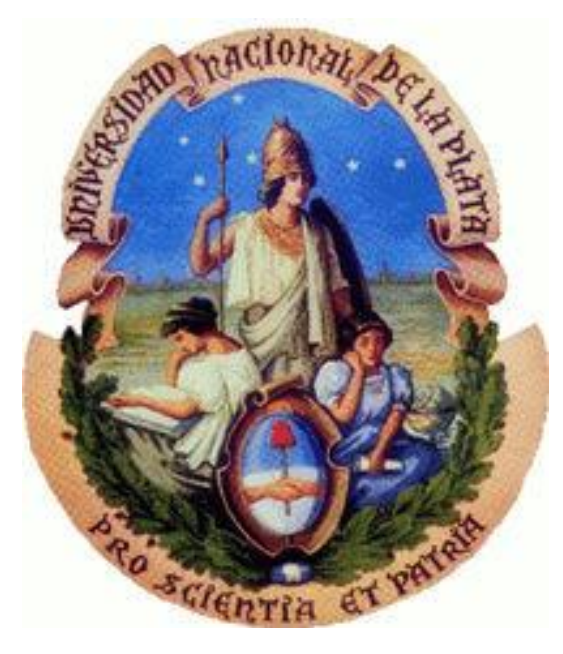

Universidad Nacional de la Plata - Facultad de Informática Tesis presentada para obtener el grado de Magister en Tecnología Informática Aplicada a Educación

\title{
Accesibilidad digital para usuarios con limitaciones visuales
}

Nombre y Apellido de la Tesista: Lic. Gabriela Alejandra Toledo

Director: Mgter. Alejandro Héctor González

Co-Directora: Dra. María del Carmen Malbrán 


\section{Agradecimientos}

Este trabajo de tesis es un punto de llegada y comienzo a la vez. Significa la puesta en palabras e imágenes de valores implícitos en mis aprendizajes de vida, ahora enmarcados en conceptos teóricos y buenas prácticas compartidas. Abre futuras líneas de compromiso con los mismos.

Vaya mi agradecimiento a quienes son co-autores de este escrito, en "trabajo colaborativo", por su presencia y apoyo.

A mi madre, siempre con buen humor y encontrando miradas, palabras y gestos que alientan mi esfuerzo y perseverancia.

A mi esposo, leal compañero en la concreción de proyectos e ideas.

A mis hijos, Daniela, Valentina y Ezequiel, por su paciencia y comprensión en la distribución del tiempo y energías, necesarios para la elaboración de esta tesis.

A Fabiana Mon, Marcos Murúa y Patricia Alegre, profesionales del Grupo CRE, dedicados a acompañar a niños con limitaciones en la visión, por recibirme con generosidad y buena predisposición en su espacio de trabajo, compartiendo su experiencia y conocimiento.

A Verónica y los demás usuarios con limitaciones en la visión que aportaron su experticia en el uso de las TIC, con una escucha paciente y lenguaje sencillo para facilitar mi comprensión.

A María Malbrán y Alejandro González, animando sistemáticamente mi producción, presentes en las respetuosas sugerencias, orientaciones y recordatorios que hacen a mi formación profesional de este momento. 


\section{$\underline{\text { Índice de contenidos }}$}

$\begin{array}{ll}\text { Introducción } & 6\end{array}$

$\begin{array}{ll}\text { Organización del trabajo } & 10\end{array}$

Marco teórico y estado del arte $\quad 12$

Capítulo I Escenario actual. Relación entre sociedad, información y comunicación

1.1 Sociedad de la información: nuevos modos de comunicación,

participación y gestión de la información y el conocimiento

1.2 Sociedad y datos que procesar. Tecnologías de la

Información y la Comunicación. TIC

1.3 La Sociedad del Conocimiento

$1.4 \quad$ Sociedades de Aprendizaje 19

1.5 Exclusión e Inclusión en la SIC. Los sujetos y las TIC 20

$\begin{array}{lll}1.6 & \text { La brecha digital } & 23\end{array}$

\section{Capítulo II TIC, Inclusión digital y Educación}

$\begin{array}{lll}2.1 & \text { Educación para la Inclusión digital } & 27\end{array}$

2.2 Las TIC como herramientas de educación 30

2.3 Procesos cognitivos involucrados en el uso de las TIC 34

2.3.1 Cognición distribuida 36

2.3.2 Inteligencia distribuida 38

2.3.3 Teoría Triárquica de la Inteligencia Humana 41

2.3.4 Modos de representación simbólica y resolución de problemas $\quad 48$ 
2.3.5 Características de herramientas digitales como

potenciadoras cognitivas

\section{Capítulo III Las TIC como herramientas facilitadoras de la inclusión}

3.1 Diseño Universal 65

$\begin{array}{lll}3.2 & \text { Diseño para todos en entornos digitales }\end{array}$

$\begin{array}{lll}\text { 3.3 La e-accesibilidad } & 71\end{array}$

$\begin{array}{lll}3.4 & \text { Usabilidad digital } & 76\end{array}$

$\begin{array}{lll}3.5 & \text { Interoperabilidad digital } & 82\end{array}$

\section{Capítulo IV Diversidad de Usuarios y Tecnologías}

$\begin{array}{lll}4.1 & \text { De los usuarios } & 85\end{array}$

$\begin{array}{lll}4.2 & \text { De la tecnología } & 89\end{array}$

4.3 Herramientas digitales que colaboran en la inclusión de los usuarios 92

4.4 Tiflotecnología. Tecnología adaptada para las dificultades visuales 96

4.4.1 Aspectos relevantes de los lectores de pantalla 104

4.4.2 El programa parlante JAWS 106

\section{Diseño Metodológico}

\section{Capítulo V Indagación del problema. Tiflotecnologías y accesibilidad}

5.1 Metodología de trabajo 113

5.2 Caracterización de la muestra 113

$\begin{array}{lll}\text { 5.3 Caracterización de los instrumentos } & 114\end{array}$

$\begin{array}{lll}5.4 & \text { Relevamiento de datos } & 115\end{array}$

$\begin{array}{lll}\text { Capítulo VI A modo de conclusión } & 126\end{array}$ 


\section{Índice de tablas, gráficos e imágenes}

Gráfico No 1 "Conformación de las TIC"

Tabla No 1 "Ubicación de Argentina según el índice networks"

Gráfica No2 "Espacios de la SIC donde las TIC facilitan

la participación de las personas con diversidad funcional"

Tabla No 2 "Cuadro resumen de las características

de las TIC y los procesos cognitivos relacionados"

Tabla No 3 "Características de espacios de trabajo con TIC"

Tabla No 4 "Estilos de aprendizaje y representaciones

simbólicas empleadas en estrategias didácticas para su fortalecimiento"

Gráfica No 3 "Áreas tecnológicas clave para la vida independiente" 64

Tabla No 5 "Siete principios del Diseño Universal"

Tabla No 6 "Dimensiones e indicadores que conceptualizan

el concepto de Calidad de Vida"

Tabla No 7 "Descripción de tipos de discapacidades,

limitaciones consecuentes y TIC pertinente para su mejora"

Imagen N01 "Magnificador de pantalla"

Imagen No 2 "Periferico Braille efímero"

Tabla No 8 "Resumen recursos tiflológicos de bajo nivel de especialización" 100

Imagen No 3 " Lupa TV"

Imagen No 4 "Braille'n Speak"

Tabla No 9 "Enumeración recursos tiflológicos de alto nivel 
Tabla No 10 "Listado de lectores de pantalla disponibles

$\begin{array}{ll}\text { en el mercado" } & 107\end{array}$

Imagen No 5 "Pantalla de inicio del programa JAWS" 108

Gráfico No 4 "Distribución de usuarios según género" 115

Gráfico No 5 "Franjas etarias y máximos niveles

educación formal alcanzado" 116

Gráfico No 6 "Distribución por frecuencia de uso de Internet" 116

Gráfico N07 "Usos de Internet" 117

Gráfico N08 "Navegadores de Internet" 118

Gráfico N09 "Frecuencia en utilización de lector de pantalla" 119

Gráfico N010 "Lector de pantalla utilizado" 119

Gráfico N011 "Motivo de elección del lector de pantalla" 120

Gráfico N012 "Páginas más consultadas" 121

Gráfico N013 "Motivo de elección de páginas consultadas" 121

Gráfico N¹4 "Acciones realizadas en las páginas" 122

Tabla N¹1 "Cuadro resumen de datos referidos a ventajas o facilidades

al acceder mediante lectores/magnificadores de pantalla"

Tabla N012 "Cuadro resumen de datos referidos a desventajas o

dificultades al acceder mediante lectores/magnificadores de pantalla" 


\section{Introducción}

El siglo XXI nos encuentra participando de acontecimientos sociales, económicos, históricos y científicos, que acompañan la construcción de nuevos significados en relación a las personas y su entorno.

Los cambios culturales y sociales que se presentan de la mano de las nuevas Tecnologías de La Información y la Comunicación (en adelante TIC), impactan en diversos ámbitos de la vida cotidiana: en las relaciones interpersonales, en entornos laborales y en el escenario educativo. La Educación afronta un desafío a la hora de educar a los ciudadanos en y para los nuevos contextos.

Los importantes avances en Tecnología relacionada con la Educación, nos ponen frente a la oportunidad de repensar el papel de ella, en relación al aprendizaje y enseñanza de las personas con necesidades educativas especiales (Alonso, C. y Santarosa, L., 2006) tales como el desarrollo de plataformas educativas; herramientas digitales de comunicación bidireccional, asincrónicas y sincrónicas; sistemas expertos, realidad virtual, que conforman los espacios virtuales de enseñanza aprendizaje EVEA.

Las computadoras personales y los sistemas informáticos tienen importancia como tecnología de soporte, herramientas para la comunicación y el aprendizaje, particularmente para aquellos que presentan diversidad funcional ${ }^{1}$ (intelectual, motriz, comunicacional, sensorial), condición necesaria para acceder a la educación inclusiva.

Son conocidos los aportes de estas tecnologías a la cognición humana cuando son empleadas como herramientas de interacción en entornos de

${ }^{1}$ El término de "diversidad funcional" hace referencia a un amplio espectro de discapacidades y minusvalías. Se propuso y comenzó a utilizarse en el Foro de Vida Independiente, comunidad virtual iniciada en España, en enero de 2005, con el objetivo de sustituir la terminología existente referida a este colectivo social. 
enseñanza/aprendizaje. (Salomón; Perkins y Globerson, 1992; Perkins, 2001; Burbules y Callister, 2001; Cabero, 2001; Sánchez Montoya, 2002)

Aún siendo importante el recorrido realizado en las tres últimas décadas y evidentes los avances de la Informática Educativa, existen cuestiones en educación de personas con necesidades especiales que merece la pena reflexionar.

Hemos puesto nuestro interés en el colectivo de personas con dificultad en la visión, limitadas en su posibilidad de percibir, registrar, decodificar, leer, la información escrita de modo corriente, quienes utilizan las TIC, como herramientas facilitadoras de acceso. Los software mayoritariamente empleados por este grupo de usuarios son los llamados lectores y magnificadores de pantalla. Los elementos de hardware refieren principalmente a periféricos que permiten la entrada/salida de la información de modo oral, y en impresión de sistema Braille.

Abordaremos uno de los ámbitos emergentes de la Sociedad de la Información y la Comunicación (en adelante SIC): la accesibilidad web y las tecnologías accesibles para todos.

El presente trabajo persigue como objetivos:

1. Recapitular y analizar los principios básicos de diseño para el desarrollo de tecnologías inclusivas.

2. Evaluar ventajas y desventajas en el uso del programa lector de pantalla (JAWS) al acceder a entornos comunicacionales, desde las variables de navegabilidad, interoperabilidad, usabilidad y colaboración en la cognición.

3. Derivar sugerencias acerca del diseño de entornos de aprendizaje colaborativo, de modo de lograr una mayor efectividad de esta herramienta digital, aplicada a personas con limitaciones en la visión en diverso grado.

4. Redactar un manual complementario de orientaciones que facilite el uso de este instrumento inclusivo, aplicado a entornos de enseñanza/ aprendizaje colaborativo. 
Tres son los planos de análisis seleccionados: la Informática, la Psicología Cognitiva y la Inclusión Social.

En primer lugar, será útil presentar someramente el escenario actual en que se desarrollan las iniciativas sociales para fomentar la inclusión de las personas con diversidad funcional. Las TIC resultan instrumentos de apoyo, capaces de facilitar la participación comunitaria y la vida corriente de estas personas.

Nos adentraremos en los conceptos de:

_ Tecnologías adaptativas, habilitadoras e inclusivas. (Alcantud Marín, 2003; Sánchez Montoya, 2006)

_Tecnología Exclusiva, de Apoyo e Invisible, contemplando la relación "persona/ordenador/entorno", según investigaciones realizadas desde las perspectivas de los usuarios. (Roig, 2007; Sánchez Montoya, 2006)

_Sistemas alternativos de comunicación con el ordenador, que facilitan el acceso a la información a personas con baja visión y/o ciegos. Tiflotecnología. (Biblioteca Argentina para Ciegos (BAC); Mon, 2006; Organización Nacional de Ciegos Españoles (ONCE)

Desde el plano de la Informática, se observarán las nociones de:

_ Accesibilidad. (World Wide Web Consortium (W3C); Web Accessibility Initiative (WAI); Berners-Lee, 2004; 2009)

__ Usabilidad. (Nielsen, 1993; Norman, 1983; 1994)

_ Interoperabilidad. (Instituto de Ingenieros Eléctricos y Electrónicos (IEEE, 2011); Dublin Core Metadata Initiative (DCMI), 2011)

_Diseño Universal o Diseño para Todos (Center for Universal Design, 1997; Mace, 2002)

Los marcos teóricos ofrecidos por la Psicología Cognitiva, implican considerar desde el usuario, la puesta en juego de: 
_Procesos, habilidades y actitudes implicadas.

_Habilidades cognitivas de monitoreo. (Sternberg, 1990; 2003; 2003a)

_Despliegue de inteligencia práctica. (Sternberg, 2003)

_Automatización de los componentes informativos de la inteligencia. (Sternberg, 1990)

_Adquisición de nueva información/capacidades. (Salomon, 1992; 2001; Sternberg, 1990)

_Aprendizaje colaborativo (papel del mediador y del grupo de aprendizaje). (Lave, 1991; Rogoff, 1993; 2003; Vigotsky, 1934)

_Cognición distribuída (rol del usuario y de los soportes facilitadores). (Hutchins, 1990; Norman, 1983; 1994; Salomon, 2001)

_ Diversificación de códigos representacionales. (Bruner, 1966;1988; 1997; 2001; Eisner, 1995; 2002; Johnson-Laird,1995; Paivio, 1969; 1971; 1986)

Son variadas las posibilidades que brindan las TIC a la inclusión educativa. Resulta relevante independientemente del rol que cumplan las personas, como protagonistas, constituyendo el grupo particular de usuarios con limitaciones sensoriales, su conocimiento permitirá mejorar la calidad de vida; y, como autores de una propuesta tecnológica/educativa, conocer qué requisitos y normas deben cumplirse en el diseño de los entornos donde se utilizan estas herramientas, para que puedan ser empleadas por amplios segmentos la población. 


\section{Organización del trabajo}

La presente propuesta de trabajo suscribe los siguientes principios:

- $\quad$ La Educación permanente es un Derecho Humano Universal

- $\quad$ Las TIC son herramientas de apoyo, potenciales colaboradoras en el desarrollo y mejora de las habilidades cognitivas.

- La cognición de los sujetos se potencia cuando los entornos de aprendizaje resultan "amigables", accesibles y usables.

- Los fundamentos del Diseño para Todos o Diseño Universal, aplicados a las TIC se traducen en mayor accesibilidad y usabilidad.

En consecuencia, se analizarán las fortalezas y debilidades en el uso de un lector de pantalla en el acceso a la información presentada. La valoración se realizará tomando los criterios de usabilidad, navegabilidad e interoperabilidad.

A partir de las actividades cognitivas puestas en juego en entornos de enseñanza/aprendizaje, de los estilos de aprendizaje que pueden observarse en un grupo de alumnos y de la evaluación de las dificultades enunciadas en la consulta a usuarios con limitaciones en la visión, se propondrán sugerencias relativas al uso de la herramienta digital y al diseño de dichos entornos como modos de facilitar la práctica.

Apartados:

- abordaje teórico,

- recolección y análisis de datos acerca de las facilidades y dificultades en el uso de herramientas digitales (lectores y magnificadores de pantalla), por parte de usuarios con limitaciones en la visión, 
- $\quad$ redacción de un manual complementario que orientará el desarrollo

de espacios virtuales de enseñanza/aprendizaje para personas con limitaciones en la visión en diverso grado. 


\section{Marco teórico y estado del arte}

\section{Capítulo I}

\section{Escenario actual. Relación entre sociedad, información y comunicación}

El siglo en que vivimos muestra contextos sociales cosmopolitas, definidos como "aldea global", o "gran aldea", donde acontecimientos históricos perfilan cambios determinantes para la humanidad: cercanía de vínculos económicos, políticos y sociales, proceso de la globalización, avance de la digitalización, reorganizaciones políticas.

Esta interrelación entre las regiones del mundo favorecería la concreción de una red de relaciones mutuas, pudiendo impulsar tanto la solidaridad como la búsqueda de ideales comunes.

En el ámbito socio-político, ocupa un lugar preferencial el concepto de persona/ciudadana, titular de derechos y obligaciones.

En este escenario la democratización, concientización, participación e inclusión resultan ser motor del desarrollo de las personas.

En concordancia con estos progresos, los Derechos Humanos enfatizan la equidad y la igualdad de oportunidades para todas las personas de derecho, sin distinciones de raza, credos o capacidades.

Desde el área de la Informática, un concepto convocante es el de "Sociedad de la información y la comunicación" (SIC) referido a un paradigma que está produciendo profundos cambios en nuestro mundo desde el comienzo de este milenio. Dicha transformación está impulsada principalmente por los nuevos medios disponibles para crear y divulgar información mediante tecnologías digitales. Los flujos de información, las comunicaciones y los mecanismos de coordinación se están digitalizando en 
muchos sectores de la sociedad, proceso que se traduce en la aparición progresiva de nuevas formas de organización social y productiva. Esta "actividad digital", que se está convirtiendo poco a poco en un fenómeno global, tiene su origen fundamentalmente en las sociedades industrializadas más maduras (Katz y Hilbert 2003)

\subsection{Sociedad de la información: nuevos modos de comunicación, participación y gestión de la información y el conocimiento}

Las tecnologías son generadas por las necesidades, ideas y creencias compartidas por un grupo social en un momento y lugar determinado. Son construcciones, producto de condiciones sociales, (procesos políticos, económicos, culturales e ideológicos). (Azinián, 2008) Dan lugar a saltos cualitativos en los modelos de sociedades. El presente, se caracteriza por el conocimiento inmediato, variadas innovaciones y sus respectivas implicancias, producidas a un ritmo vertiginoso.

La configuración de un nuevo entorno, no anula o elimina el anterior, ambos conviven. Algunas personas siguen ancladas en modos establecidos de afrontar las situaciones, otras rechazan toda posibilidad de cambio, otras aprenden a vivir en el nuevo entorno, haciendo propios dichos cambios y afrontando las exigencias de la nueva sociedad, y algunos no tienen posibilidad de acceder a estos cambios, quedando fuera de la realidad emergente. (García Aretio, Ruiz Corbella y Rodriguez Figaredo, 2006)

El concepto de "sociedad de la información" es complejo.

Distintos autores enumeran las características significativas de esta sociedad de la información, del conocimiento, del aprendizaje en red, o tercer entorno, como ha sido definida (Reigeluth, 1996; Marchesi y Martín, 1998; Tezanos, 2001; Cabero, 2001; Majó y Marqués, 2002; Coll y Monereo, 2008). Algunas de ellas son: 
- Globalización de las actividades económicas.

- Incremento del consumo y producción masiva de los bienes de consumo.

- $\quad$ Sustitución de los sistemas de producción mecánicos por otros de carácter electrónico y automático.

- $\quad$ Flexibilización del trabajo e inestabilidad laboral.

- Aparición de nuevas modalidades de trabajo, como el teletrabajo, dando lugar a la aparición de nuevos sectores laborales.

- $\quad$ Empleo de las TIC, relacionando los campos de la informática y la telemática, y como consecuencia, potenciación de la creación de infraestructura tecnológica.

- Globalización de los medios de comunicación de masas convencionales, e interconexión de tecnologías tradicionales y novedosas, permitiendo romper las barreras espacio-temporales, abarcando grandes distancias.

Una de las acepciones más empleadas de la SIC es aquella que considera a la sociedad conformada por espacios, donde la creación, distribución y manipulación de la información forman parte importante de sus actividades culturales y económicas.

Si analizamos los elementos que dan cuerpo a esta definición de sociedad, se ve que están referidos a las características de las Tecnologías de la Información y la Comunicación y al proceso de digitalización de la información que se deriva del uso de las mismas y que permite la comunicación entre las personas.

\subsection{Sociedad y datos que procesar. Tecnologías de la Información y la Comunicación. TIC}

Las personas se encuentran en interacción recíproca y basan su comportamiento en el intercambio de información y en la comunicación. Los canales comunicativos utilizados son los que nos permiten registrar esta interacción: gestos, expresiones faciales, movimientos corporales, 
habla, textos impresos. En las relaciones humanas resulta inconcebible no comunicarse (Watzlawick, Beavin y Jackson, 1990).

Actualmente, la interacción de las personas se encuentra mediada en gran medida por elementos tecnológicos digitalizados.

El proceso llamado digitalización, donde los datos se traducen en "ceros y unos" comenzó décadas atrás y se acelera a medida que evolucionan las soluciones informáticas conocidas como Tecnologías de la Información y la Comunicación. ${ }^{2}$

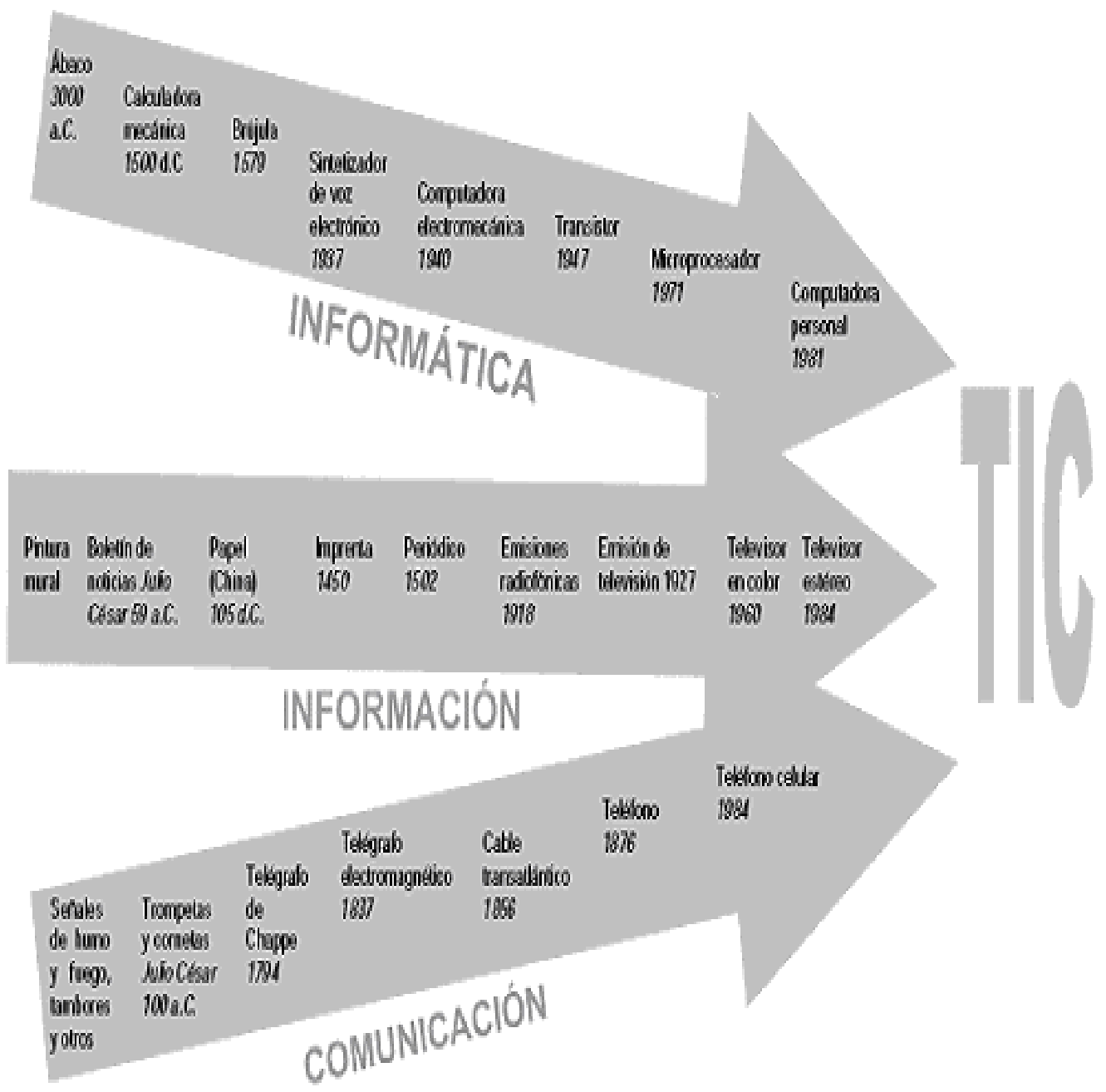

Gráfico No 1 "Conformación de las TIC". Adaptado de ${ }^{3}$

${ }^{2}$ Estas comprenden la convergencia o fusión de tres caminos tecnológicos que se encontraban separados, en un único sistema que de forma simplificada es denominado TIC.

3 Hilbert, Martín "Toward a theory on the information socierty"; "Infraestructure"; "Strategies"; "Teleconunications regulation: tecnical standards"; "Financing a universal 15 
Según Cabero (2003) las TIC comprenden un conjunto de servicios, redes, software y dispositivos que tienen como fin la mejora de la calidad de vida de las personas dentro de un entorno, y que se integran a un sistema de información interconectado y complementario. Permiten realizar cosas completamente diferentes a las realizadas con las tecnologías tradicionales; de ahí que un criterio, para su definición, no pueda ser exclusivamente, el hecho de que nos permitan hacer las cosas de forma más rápida, automática y fiable.

Al emplear las TIC, los datos residen en el espacio virtual conocido como ciberespacio, que los globaliza. Prestando atención al orden de la sigla, puede verse la importancia otorgada a los términos a lo largo de la historia, desplazándose el énfasis puesto en un comienzo en la tecnología, luego en la información y en el presente en la comunicación.

En el entorno educativo, entendemos por TIC, "todos los medios desarrollados en torno al surgimiento de la ciencias de la Informática, que permiten la comunicación e interacción con fines educativos; de manera sincrónica o asincrónica; de forma individual o colectiva; que utilizan la computadora como principal medio de comunicación e interacción entre los sujetos del acto educativo y que permiten acceder a recursos y servicios desde computadoras distantes. Dentro de esta categoría se encuentran: el hipertexto, los multimedia, Internet, grupos de discusión, video-enlaces, correo electrónico, las charlas sincrónicas o chats, entre otros." (Herrera Batista, 2004)

Para Burbules y Callister (2001), son "artificios que modifican las percepciones que las personas tienen de si mismas como agentes, sus relaciones mutuas, sus interpretaciones del tiempo y de la velocidad, sus posibilidades de hacer pronósticos, etc., en suma, todas las dimensiones

Information Society for all"; "e-Business: digital economics"; "Building an Information Society: a Perspective form Latin America and the Caribbean, serie Libros de la CEPAL, No 72 (LC/G.2199-P), Martín Hibert y Jorge Datz (comp), Santiago de Chile, Comisión Económica para América Latina y el Caribe (CEPAL), 2002. 
del cambio en la forma de pensar sobre los medios y fines, objetivos y eficacia".

La flexibilidad que permiten para la interacción entre los sujetos y los contenidos a aprender, enfatiza su función educativa, porque "apoyan la presentación de determinados conceptos, lo que puede ayudar a guiar, facilitar y organizar la acción didáctica, así como condicionan el tipo de aprendizaje a obtener, ya que pueden promover diferentes acciones mentales en los alumnos" (Cabero, 2000).

Se caracterizan por los rasgos de inmaterialidad, interactividad, instantaneidad, innovación, interrelación de imagen y sonido, digitalización, influencia más de los procesos que de los productos, interconexión y diversidad (Cabero, 2001).

\subsection{La Sociedad del Conocimiento}

El conocimiento que posibilita actuar, comunicar y colaborar con otros sujetos, actualmente es uno de los valores más preciados de la sociedad.

La expresión de "Sociedad del Conocimiento" (knowledge society) surgió hacia finales de los años 90 y es empleada particularmente en medios académicos, como alternativa al concepto de "sociedad de la información".

Es así que se ha adoptado el término "sociedad del conocimiento", o su variante "sociedades del saber", con la intención de plantear espacios de reflexión y acción buscando que la comunicación y la información estén al servicio de la transmisión del conocimiento. Recupera la idea de que la interacción con los otros, presentes o no, es inherente al ser humano, logrando que la transmisión entre sujetos se arraigue en el tiempo, se extienda en el espacio y funcione entre las generaciones y las culturas.

El saber propio de las personas, conformando sus experiencias de vida y trabajo, es conocimiento tácito. Si se explicita, se comparte, documenta y comunica, pasa a ser información recibida por otros, que, a su vez, podrán convertirlo en conocimiento distribuido. 
Es posible el conocimiento en el compartir de las comunidades que lo crean, le dan utilidad, lo transforman según sus necesidades.

Peter Drucker (1994) introduce a principios de los años 70 la noción de Sociedad del Conocimiento. La describe como la sociedad que permite una rápida adaptación a los cambios, significando esto una vía de solución a los problemas económicos. De esta manera, se considera a la circulación de conocimiento entre las personas como el motor de desarrollo o disparador económico de la sociedad.

Para Drucker la nueva forma de trabajar se relaciona con la intencionalidad de aplicar conocimiento para generar más conocimiento, hecho basado en un elevado esfuerzo de sistematización y organización. Este cambio de paradigma le permite hablar del tránsito de una sociedad industrial a una sociedad del conocimiento.

La denominada revolución de la información es, según Drucker, una revolución del conocimiento, es la reorganización del trabajo tradicional basado en siglos de experiencia, mediante la aplicación de saberes y en especial del análisis sistemático y lógico que se hace de los mismos.

La idea de conocimiento se une así a la de información, concepto que ya se utilizaba para designar al nuevo tipo de sociedad, a fin de formar parte de procesos comunicativos de intercambio simbólico.

La Sociedad de la Información y el Conocimiento, SIC, resulta atravesada en sus varias actividades (industria, entretenimiento, educación, organización, servicios, comercio, etc.) por procesos comunicativos. Se presenta como una sociedad cuyo capital básico es la inteligencia colectiva y la información, distribuída en todos los sectores, continuamente valorizada y puesta en cooperación para el desarrollo social. Se caracteriza por la capacidad de sus miembros para obtener y compartir importante cantidad de información de manera prácticamente instantánea, desde cualquier lugar y en la forma deseada por los interlocutores, con un coste muy bajo (Coll y Monereo, op.cit.). 
Al referirnos a la Sociedad de la Comunicación, se pasa de la recuperación de la información a la construcción interior del conocimiento propio. Los conceptos, ideas, imágenes, y no las "cosas", son los auténticos artículos con valor en la nueva economía. La riqueza ya no reside en el capital físico, sino en la imaginación y la creatividad (Rifkin, 2000) Se trata de una sociedad cognitiva.

\subsection{Sociedades de Aprendizaje}

Los conocimientos de una época, que deben ser aprendidos por los alumnos, y los problemas que se resuelven con dichos conocimientos, están en estrecha relación con los modos de vida en sociedad y de las tecnologías que se encuentran asociadas a esos modos. La cognición (actividad perceptiva, memoria, razonamiento y resolución de problemas) se vincula con los elementos culturales disponibles en un momento histórico dado: los artefactos y los datos.

La sociedad del aprendizaje, comprende el sistema en el que las personas, una vez formadas en el uso de las nuevas tecnologías, no se limitan a recibir de forma pasiva la información sino que adquieren las capacidades necesarias para utilizar los recursos con los que interpretarla con criterio y compartirla, enriqueciéndola (Carrascosa, 2000 en García Aretio, 2007)

En esta sociedad lo importante no es exclusivamente el acceso a la información, sino identificar aquella que es necesaria, seleccionarla e interrelacionarla con lo que la persona ya conoce. Lo importante está en el logro de este proceso, en el aprendizaje, y no tanto en la posesión de los conceptos, hechos y principios que se transmiten. 
Observando las características de la sociedad actual, queda justificada la necesidad de pensar en una propuesta educativa que acompañe y facilite a las personas la participación plena como ciudadanos, accediendo y construyendo conocimiento.

\subsection{Exclusión e Inclusión en la SIC. Los sujetos y las TIC}

Si bien existen grandes distancias en el acceso a las TIC entre las naciones y entre los individuos, todos los países tienen al menos una franja de su sociedad que las ha sumado como herramientas a sus actividades. A modo de ejemplo, tomando datos correspondientes a la región a la que pertenece nuestro país, puede observarse que aún los países que se muestran más rezagados, tienen una tasa de crecimiento que denota una aceleración de las políticas orientadas a cerrar la "brecha digital" ( Tabla n¹) (ITU, 2007). 
Tabla no 1 "Ubicación de Argentina según el índice networks" Fuente UTI 2007: Índice NETWORKs ${ }^{4}$ de la UIT para Latinoamérica 2005

\begin{tabular}{|l|c|c|}
\hline \multicolumn{1}{|c|}{ Países } & Tasa de & $\begin{array}{c}\text { Tasimiento } \\
\text { Crecim } \\
\text { Anual Promedio } \\
\mathbf{2 0 0 1 / 2 0 0 5}\end{array}$ \\
\hline Chile & 176 & \\
\hline Argentina & 149,4 & 36,2 \\
\hline Uruguay & 145,9 & 37,9 \\
\hline Colombia & 131,4 & 37,7 \\
\hline Brasil & 124,2 & 49,5 \\
\hline Costa Rica & 121,2 & 56,4 \\
\hline México & 113,7 & 40 \\
\hline Panamá & 109,4 & 41,6 \\
\hline Ecuador & 105,3 & 21,3 \\
\hline Venezuela & 102 & 51 \\
\hline El Salvador & 92,8 & 36,7 \\
\hline República Dominicana & 86,4 & 48 \\
\hline Guatemala & 84,5 & 31,4 \\
\hline Perú & 73,6 & 43,8 \\
\hline Bolivia & 67,7 & 46 \\
\hline Paraguay & 64,7 & 24,4 \\
\hline Honduras & 57,7 & 28,4 \\
\hline Nicaragua & 48,3 & 35,7 \\
\hline Cuba & 24,4 & 35,8 \\
\hline & & 46,8 \\
\hline
\end{tabular}

La influencia que el paradigma tecnológico tiene puede observarse en la utilización de las TIC. No sólo están presentes en la esfera económica, sino

\footnotetext{
${ }^{4}$ El índice "NETWORKs" está compuesto por: 1) Índice de redes, que a su vez computa líneas fijas cada100 habitantes, suscriptores móviles cada 100 habitantes y ancho de banda internacional para Internet (kbps. por habitante); 2) el índice de capacidades, que surge de la tasa de alfabetismo y la tasa bruta de matrícula escolar; 3) Índice de captación, que se compone de computadoras cada 100 habitantes, usuarios de Internet cada 100 habitantes y porcentaje de hogares con TV; 4) Índice de intensidad, que surge de de la cantidad de suscriptores cada 100 habitantes del servicio de Internet en banda ancha y la cantidad de minutos per cápita del tráfico internacional de telefonía. La presencia de las TIC en lo cotidiano, invita a analizar las diferencias en el acceso y utilización, e intervenir en su desarrollo, pues el conocimiento, dentro del proceso de comunicación, deber ser considerado un bien público que ha de estar a disposición de Todos.
} 
en los ámbitos de la salud, la política, la administración pública, la educación e investigación, en actividades culturales, sociales, religiosas, donde han sido ampliamente aceptadas.

El empleo y desarrollo de las TIC, y el consecuente proceso de digitalización en los distintos sectores de la sociedad no están libres de obstáculos. Son numerosas las personas que ven restringida la oportunidad de adquirir y hacer uso de los conocimientos de esta manera.

Dentro de esta trama de relaciones, comienza a manifestarse una nueva forma de exclusión, llamada "brecha digital", ampliando la distancia que separa a las regiones y a los países, entonces denominada "brecha digital internacional", y a los grupos de ciudadanos de una misma sociedad, es decir, "brecha digital doméstica" (ALADI, 2003).

Para brindar un panorama geográfico acerca de la conformación de la SIC, pueden tomarse como referencia el índice que combina 11 indicadores en una única medición que puede ser utilizada como herramienta de comparación a nivel mundial, regional y de cada país, desarrollado por la Unión Internacional de Telecomunicaciones (ITU, 2010).

Los indicadores seleccionados muestran datos en relación al acceso de los diferentes países a las TIC, su utilización y los conocimientos y disponibilidades relacionadas, tales como la cantidad de hogares con una computadora, cantidad de usuarios de Internet y niveles de conocimientos de los usuarios.

Un breve resumen del informe, muestra que los países más avanzados en materia de TIC corresponden al Norte de Europa, junto con la República de Corea. Suecia encabeza el nuevo Índice de Desarrollo TIC de la UIT, seguida por la República de Corea, Dinamarca, Holanda, Islandia y Noruega. Luego siguen otros países de altos ingresos, principalmente de Europa, Asia y Norteamérica.

Los países menos desarrollados figuran en el extremo inferior del índice con un acceso limitado a la infraestructura TIC, que incluye telefonía fija y 
móvil, Internet y banda ancha, y hogares con computadoras conectadas a Internet. $^{5}$

La diseminación de las TIC ocurre en el marco de una "globalización asimétrica"t $^{\prime 6}$ que refleja desequilibrios que exceden las variables tecnológicas.

Esta fragmentación se encuentra vinculada a la limitación al acceso y uso que se da a las TIC, de manera que impacten positivamente en la vida de los usuarios. Comprende tres condiciones:

- disponibilidad de infraestructura de telecomunicaciones y redes.

- accesibilidad a los servicios que ofrece la tecnología

- habilidades y conocimientos para hacer un uso adecuado de la tecnología.

\subsection{La brecha digital}

Como hemos mencionado, una de las características de la comunidad mundial actual es la interconexión. La capacidad de acceder a la información y transformarla en conocimientos significativos y útiles, es un vector esencial de desarrollo social sostenible.

Las TIC son, en nuestro contexto, la principal vía de acceso y transmisión de información y constituyen, a un mismo tiempo, una mayor y mejor oportunidad para las personas con diversidad funcional, y pueden suponer también una forma de exclusión que marque importantes diferencias entre aquellos que pueden hacer uso de la tecnología y aquellos colectivos que tienen limitaciones de acceso (Negre, 2011).

Cabero (2004) define a la brecha digital como la diferenciación producida entre aquellas personas, instituciones, sociedades o países, que pueden

\footnotetext{
${ }^{5}$ Para ampliación de los datos, puede consultarse Measuring the Information Society - The ICT Development Index. 2010

6 "Globalización asimétrica" es un término acuñado por Manuel Castells (1996) en La sociedad red, Madrid, Alianza Editorial. Refiere a la relación entre sociedad y economía una participación y capacidad para influir en el sistema dependiente del grado de desarrollo y naturaleza de las competencias
} 
acceder a la red, y aquellas que no pueden hacerlo; es decir, puede ser definida en términos de la desigualdad de posibilidades que existen para acceder a la información, al conocimiento y la educación mediante las nuevas tecnologías.

En una sociedad donde los grupos sociales se encuentran cada vez más fragmentados, las TIC son canales de circulación de representaciones e ideas en torno a las cuales la población segmentada puede encontrar puntos de contacto y conexión. Desde esta perspectiva, las TIC tienen una función cultural central: construir el conocimiento que los sujetos tienen sobre la sociedad que habitan (Batista, 2007).

Contemporáneamente a la mencionada "brecha digital", que ocasiona situaciones de exclusión, se establecen los principios del paradigma social de la inclusión.

La inclusión consiste en el cambio, diseño, adaptación o transformación del ambiente en función de las necesidades, intereses y expectativas de las personas (Malbrán, 2005).

Persigue la construcción de una comunidad solidaria que valore la diversidad, la dignidad de vida y el respeto por los derechos de todos, donde las declaraciones, acuerdos y convenciones dejan de ser letra muerta o conocimiento inerte para convertirse en realidades. Encarna una visión que es al mismo tiempo optimista y realista, pues comparte logros tangibles en distintos ámbitos y niveles.

Esta concepción representa una mirada superadora de posturas negativas o fatalistas ante las diferencias individuales y/o sociales. Vela por la salvaguarda de los derechos de sectores sociales particularmente vulnerables. 


\section{Capítulo II}

\section{TIC e Inclusión digital y Educación}

Los beneficios de la SIC tienen que ser compartidos por la sociedad en su conjunto, incluyendo aquellos grupos de personas que encuentran mayores dificultades para utilizar las TIC.

Es así que surge como desafío, que las personas en general, logren vivir acorde a las exigencias de este nuevo tipo de sociedad, estar informados y actualizados, y contribuyan con sus innovaciones o invenciones. El reto se encuentra principalmente en generar propuestas y conocimiento, haciendo uso de las herramientas informáticas, tecnológicas y de los datos que pueden intercambiarse.

Al constituir la computadora un rasgo típico de la cultura actual, su incorporación en los proyectos destinados al desarrollo de procesos y disposiciones cognitivas relacionados con la educación formal e informal, puede considerarse una necesidad.

Es básico lograr el desarrollo de nuevas competencias personales, sociales y profesionales, relacionadas directamente con una competencia necesaria para formar parte de la sociedad, antes de estar presente la tecnología: la comunicativa.

Estas competencias se desarrollan no sólo en la infancia, sino a lo largo de toda la vida de las personas en ámbitos formales, no formales e informales. "Lo importante es formar personas preparadas para poder aprender continuamente, pero tan importante como tener la capacidad de aprender es la actitud de desaprender es decir, la aceptación de la caducidad de los propios conocimientos y la aceptación del cambio necesario" (García Aretio, op.cit) 
El esfuerzo por zanjar la división digital da lugar a la mirada de la einclusión, o inclusión digital. Este concepto, es definido en la página Web de la Comisión Europea (2008) como la estrategia que pretende asegurar que las personas con alguna desventaja no sean excluidas de esta sociedad debido a su falta de alfabetización digital o acceso a Internet. (European Commission, 2008)

E-inclusión permite aprovechar los beneficios que ofrecen las nuevas oportunidades generadas por los servicios digitales y técnicos para la inclusión social de las personas con diversidad funcional y grupos de alta vulnerabilidad.

Las TIC empleadas en el ámbito doméstico, social, educativo y laboral, facilitan la participación de los usuarios con diversidad funcional en el entorno que conforma la SIC (Gráfico n²).

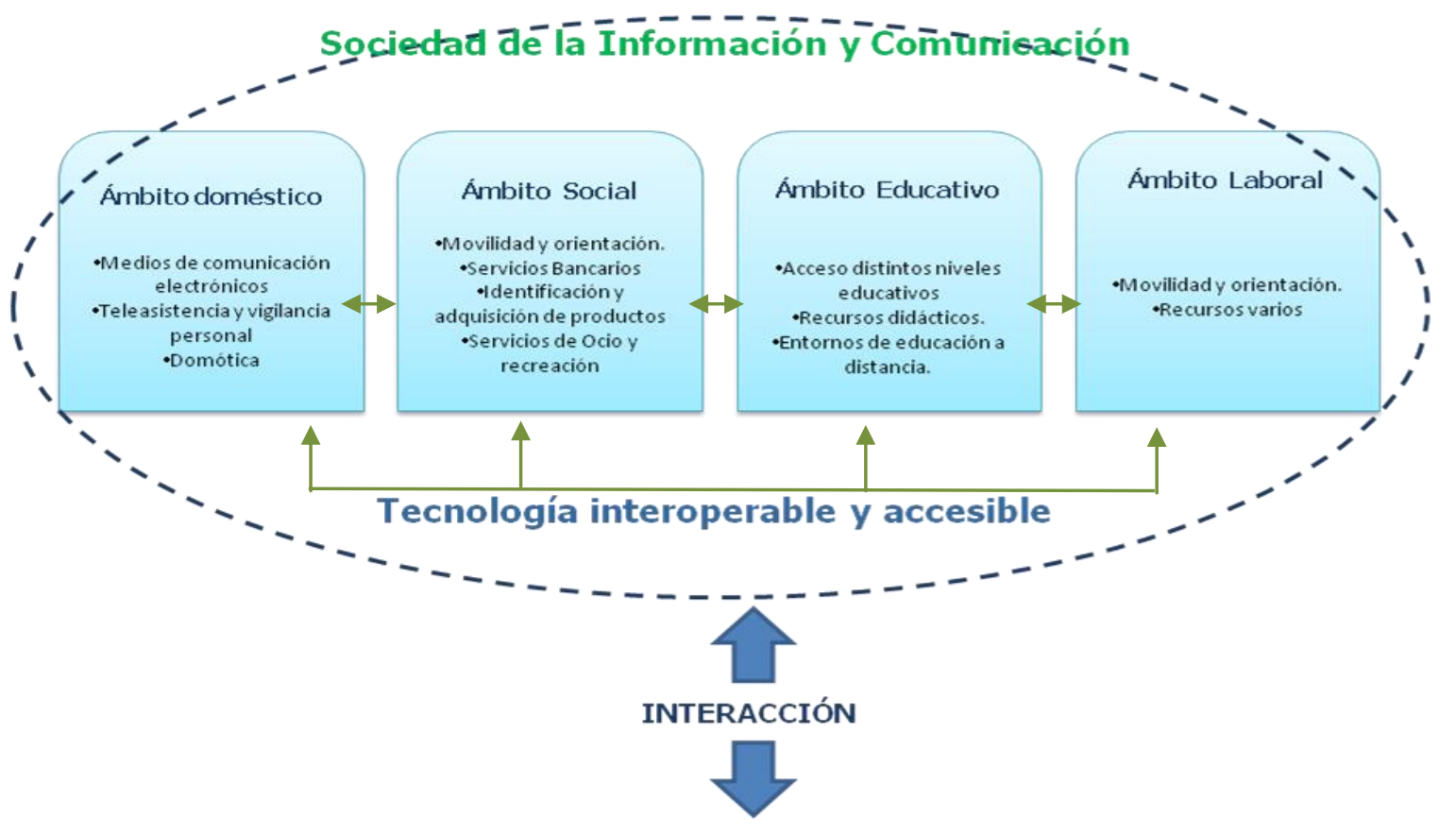

Usuarios con diversidad funcional

Gráfica n² "Espacios de la SIC donde las TIC facilitan la participación de las personas con diversidad funcional" 
Un incluido digital utiliza el nuevo lenguaje para intercambiar correos electrónicos, escribir textos, realizar cálculos, navegar por páginas en Internet, es decir, para moverse en el mundo digital, y que hace uso de este soporte para mejorar sus condiciones de vida.

A partir de la concepción de la SIC, la utilización de las herramientas tecnológicas ha presentado dos miradas que coexisten: en los comienzos, un tipo de euforia que ensalzaba el potencial de las mismas, como ocurrió con otros cambios tecnológicos anteriores, para dar lugar luego a un escepticismo, por las nuevas barreras que estas representan para quienes tienen dificultades al emplearlas.

\subsection{Educación para la Inclusión digital}

La confluencia de las TIC es el escenario que genera transformaciones en los modos en que se organizan, idean y articulan los procesos educativos. Sin ánimo de ser exhaustivos, es posible nombrar una serie de elementos, propios de la SIC, de relevancia para comprender el panorama actual en que se desarrolla la educación (Coll y Monereo, op.cit.):

1. Complejidad, interdependencia e imprevisibilidad que rigen las acciones y relaciones de las personas.

2. Información, sobreinformación y ruido. La información es la materia prima de la SIC. Las TIC incrementaron la cantidad y el flujo de información, facilitando el acceso a la misma de sectores cada vez más amplios de población. Si se poseen limitados criterios para seleccionar y contrastar la veracidad, la abundancia de información se convierte en sobreabundancia, caos y ruido. Encierra un potencial para el desarrollo individual y social.

3. Rapidez de los procesos y sus consecuencias. Los cambios y transformaciones veloces de la información, implican la pérdida de vigencia de la misma. 
4. Escasez de espacios y tiempos para la reflexión y abstracción. Existe una compulsión a pensar rápido antes que en pensar mejor. La rapidez de las transformaciones, la sobreabundancia, obsolescencia y renovación incesante de la información, pueden dar lugar a la disminución de la atención, superficialidad, estandarización de los mensajes, a una pobre comunicación.

5. Preeminencia de la cultura de la imagen y del espectáculo. Puede observarse una primacía de lo sensorial y lo concreto sobre lo abstracto y simbólico, de lo narrativo sobre lo taxonómico y analítico, de lo dinámico sobre lo estático, de las emociones sobre la racionalidad.

6. Transformación de las coordenadas espaciales y temporales de la comunicación; se supera la limitación de tiempo y espacio mediante el uso de las TIC. El ciberespacio, el espacio virtual en que tiene lugar la comunicación por redes, es en realidad un "no lugar", un "espacio no físico" distinto a los espacios personales en los que se encuentran físicamente los interlocutores (Martínez y Solano, 2003)

Uno de los retos planteados al ciudadano es la formación para la participación plena en la sociedad, con sus características de globalidad, donde los límites geográficos se desdibujan, quedando los culturales y legales. Para lograrlo es necesario dominar las nuevas tecnologías, tener acceso a las más variadas formas de información y de comunicación y, a la vez, una sólida formación cultural y ética.

De este modo, "la educación es vista como el mejor medio que se dispone para comprender el mundo, de manera que se pueda evitar una sociedad dividida entre los que pueden interpretar el mundo que les rodea, los que sólo saben utilizar informaciones fragmentadas y los que definitivamente se quedan al margen" (García Aretio, op.cit.). 
Mediante la educación, surge la posibilidad de un mundo más inclusivo. Es instrumento por excelencia para lograr el desarrollo personal y la inclusión social. Permite el cambio planteado por la SIC, que no se encuentra exclusivamente en las posibilidades y capacidades que ofrecen las TIC, sino en su participación en la potenciación de la capacidad del ser humano de conocer, trabajar y aplicar ese conocimiento.

Ante la necesidad de saber interactuar en el presente contexto tecnológico, es una habilidad imprescindible saber seleccionar, filtrar, ordenar, valorar y asimilar la información para poder convertirla en conocimiento útil (Majó op.cit). El punto de atención estará en tener las competencias necesarias para acceder y transformar los contenidos, datos, información en saber. Así la educación es requisito para acceder al "entorno telemático".

En palabras de Burbules (2008) "la tecnología nunca es sólo una máquina o un objeto en sí mismo; es siempre el objeto y cómo se utiliza".

Para que la inclusión digital tenga lugar, se requieren:

- $\quad$ el ordenador, o computadora

- $\quad$ el acceso a la red de información digital,

- $\quad$ el dominio de estas herramientas.

La inclusión digital está inserta en un movimiento de mayor amplitud que éste, el de la inclusión social, considerado uno de los objetivos compartidos por diversas sociedades alrededor del mundo de las últimas décadas.

Los ciudadanos deben poseer los conocimientos necesarios para vivir y trabajar en la nueva SIC. Se hace necesario poseer estas nuevas competencias básicas en materia de Tecnologías de la Información, diferentes idiomas, cultura tecnológica, y habilidades para la socialización dentro del ciberespacio de nuevas relaciones. (Area Moreira, 2009) 
Por "competencia" se entiende una combinación de conocimientos, capacidades y actitudes necesarios para la resolución de una determinada situación. Las "competencias clave" son aquellas sobre las que se sustentan la realización personal, la inclusión social, la ciudadanía activa y el empleo. (Parlamento Europeo y Consejo de la Unión Europea, 2006) ${ }^{7}$

Las «e-competencias» pueden ser definidas como aquellas capacidades, destrezas y habilidades utilizadas por las personas, paralelamente en dos aspectos:

1. aplicar y compartir conocimientos tácitos y explícitos propios del sujeto y de la red social a la que tiene acceso inmediato o mediado,

2. utilizar las tecnologías digitales en la gestión de información, construcción de entornos personalizados de aprendizaje, generación del conocimiento para sustentar el trabajo colaborativo, construcción de sinergias, la innovación y la creatividad constante frente a problemas o contextos en permanente transformación.

\subsection{Las TIC como herramientas de educación}

Al incorporar las nuevas tecnologías al ámbito cotidiano en la educación, las estrategias de trabajo permiten modificar el enfoque centrado en el maestro/profesor, organizado principalmente en clases magistrales, facilitando una metodología enfocada en el alumno. Las TIC ofrecen un variado espectro de herramientas que pueden colaborar en dicha transformación logrando entornos de conocimiento ricos, interactivos y

7 Recomendación del Parlamento Europeo y del Consejo de 18 de diciembre de 2006 sobre las competencias clave para el aprendizaje permanente (2006/962/CE). Consultado 21 diciembre 2011 en http://eurlex.europa.eu/LexUriServ/LexUriServ.do?uri=CELEX:32006H0962:ES:HTML 
centrados en el alumno. (Cabero, 2004 op.cit) Permiten abrir la variación de los recursos pedagógicos, rescatando aquellos instrumentos culturales y prácticas sociales cotidianas, que conforman el contexto sociocultural en que se encuentra inmersa una situación de enseñanza/aprendizaje.

Si bien esta incorporación no transforma ni mejora de manera automática los procesos educativos, modifica de manera sustancial el contexto en que ocurren dichos procesos, las relaciones entre los sujetos involucrados, las tareas y los contenidos a aprender (Coll y Monereo, op.cit.).

En relación a las concepciones actuales referidas al aprendizaje, estas herramientas resultan válidas para la construcción de entornos de aprendizaje colaborativos favorecedores de procesos cognitivos. Ofrecen posibilidades de trabajo, producto de dos aspectos centrales:

> Permiten el acceso a una cantidad de información utilizable en el mundo, de mayor envergadura a la que existía hace sólo pocos años con un ritmo de crecimiento que continúa acelerándose.

> Posibilitan una comunicación más eficaz, veloz y desdibujan las limitaciones de distancia y tiempo.

Según Coll y Martí (2001) algunas de las características destacadas de los ordenadores que muestran consecuencias claras en los procesos cognitivos de los sujetos que las utilizan, pueden organizarse según muestra la tabla n02. 
Tabla No 2 "Cuadro resumen de las características de las TIC y los procesos cognitivos relacionados" ${ }^{8}$

\begin{tabular}{|c|c|}
\hline Formalismo & $\begin{array}{l}\text { Implica la previsión y la planificación de las acciones; en } \\
\text { consecuencia, diferenciación entre medios y fines. }\end{array}$ \\
\hline Interactividad & $\begin{array}{l}\text { Favorece una relación más activa y contingente con la } \\
\text { información. Potencia el protagonismo del aprendiz. }\end{array}$ \\
\hline Dinamismo & $\begin{array}{l}\text { Ayuda a trabajar con simulaciones de situaciones reales. } \\
\text { Permite interactuar con realidades virtuales. }\end{array}$ \\
\hline Multimedia & $\begin{array}{l}\text { Posibilita la integración, complementariedad y tránsito } \\
\text { entre diferentes sistemas y formatos de representación. }\end{array}$ \\
\hline Conectividad & $\begin{array}{l}\text { Permite el trabajo en red de agentes educativos y } \\
\text { aprendices. }\end{array}$ \\
\hline Hipermedia & $\begin{array}{l}\text { Contempla la posibilidad de establecer formas diversas y } \\
\text { flexibles de organización de las informaciones, } \\
\text { estableciendo relaciones múltiples y diversas entre ellas }\end{array}$ \\
\hline
\end{tabular}

${ }^{8}$ Fuentes: Martí, 1992; Coll y Martí, 2001; Coll, 2003; Martí, 2003 
Desde los estudios realizados por Hung y Der-Thanq (2001), con base en el pensamiento vigotskiano y los principios de la cognición situada pueden distinguirse cuatro aspectos de los espacios de trabajo con TIC, relacionados con la propuesta de Coll y Martí. (Tabla n³).

Tabla no 3 "Características de espacios de trabajo con TIC"

\begin{tabular}{|c|c|}
\hline Carácter situacional & $\begin{array}{l}\text { Implica un trabajo por tareas y proyectos } \\
\text { organizados según los conocimientos } \\
\text { explícitos e implícitos, en función de } \\
\text { necesidades y demandas del grupo de } \\
\text { usuarios/alumnos. }\end{array}$ \\
\hline Comunalidad & $\begin{array}{l}\text { Abarca los intereses y problemas } \\
\text { compartidos por los miembros de la } \\
\text { comunidad que interactúa; facilita la } \\
\text { prosecución de metas compartidas. }\end{array}$ \\
\hline Interdependencia & $\begin{array}{l}\text { Los usuarios muestran diferencias en } \\
\text { conocimiento, habilidades, perspectivas, } \\
\text { opiniones y necesidades en relación a las } \\
\text { distintos temas, lo que supone la } \\
\text { asunción de roles de experto y novato de } \\
\text { modo alternado, entablándose relaciones } \\
\text { de beneficio mutuo al interior del grupo. }\end{array}$ \\
\hline Infraestructura & $\begin{array}{l}\text { Implica la existencia de reglas o sistemas } \\
\text { que promueven la motivación y } \\
\text { participación, } \\
\text { una serie de mecanismos de rendición de } \\
\text { cuentas } \\
\text { de los participantes y la disposición de } \\
\text { estructuras de facilitación de la } \\
\text { información y la interdependencia. }\end{array}$ \\
\hline
\end{tabular}

Las características antes mencionadas pueden identificarse en entornos de aprendizaje con un sentido "potencial", pues la simple utilización de TIC no implica ni la mejora de los procesos cognitivos de los usuarios, ni el logro 
de aprendizajes significativos o la promoción de habilidades complejas de pensamiento. La propuesta de uso de las TIC debe tener intencionalidad para asegurar un mejor logro de dichas características y sus consecuencias cognitivas.

Tienen, como veremos, la potencialidad de modificar los procesos de gestión del conocimiento y contribuyen en tres aspectos particulares de situaciones de enseñanza y aprendizaje:

- autonomía en la gestión del conocimiento;

- co-construcción de conocimiento;

- conexión entre contextos educativos formales e informales.

\subsection{Procesos cognitivos involucrados en el uso de las TIC}

Al utilizar la tecnología digital con fines educativos en las aulas, el aprendizaje tiene lugar en un entorno donde la complejidad, la multiplicidad de destinatarios y la capacidad de integración, brinda un espacio donde la información está vinculada con la descentralización del conocimiento, la flexibilidad cognitiva y la tolerancia a la ambigüedad. (González, A. 2008)

Como sostiene Sancho Gil (2002) una de las características más genuinas de las TIC es la versatilidad, ofreciendo un conjunto diversificado de prestaciones. Esto permite explicar por qué prácticamente todas las perspectivas sobre la enseñanza y el aprendizaje pueden argumentar haber encontrado en el ordenador un aliado de valor.

Las perspectivas conductistas y neoconductistas de la enseñanza encontraron en la computadora una precursora máquina de enseñar, un sistema experto o tutor inteligente, desarrollando importantes actividades 
en el ámbito del diseño y desarrollo de programas de enseñanza asistida por ordenador. (Skinner, 1968, 1969,1989, 1970, 1973)

La postura cognitiva, toma los procesos realizados por las computadoras como metáfora explicativa del funcionamiento del cerebro humano, ve en ella una herramienta capaz de realizar acciones humanas (calcular, tomar decisiones, enseñar...), y considera que las actividades mediadas por ésta presuponen el desarrollo de capacidades cognitivas y metacognitivas (resolución de problemas, planificación, algoritmización de tareas, etc.) Desde esta óptica, el estudio, la experimentación y la exploración de la información, mejora la motivación, el rendimiento y las capacidades cognitivas (Bransford y Vye, 1996; Gardner, 1991, 1993, 2006; Salomon, 2001).

Las teorías que analizan al aprendizaje poniendo especial atención en la expresividad y la diversificación de los códigos utilizados para representar la información, encuentran en las TIC una respuesta interesante, útil para favorecer la motivación y el rendimiento de los sujetos mediante la integración de textos, gráficos, lenguajes audiovisuales e icónicos, al momento de diseñar una propuesta de enseñanza/aprendizaje. (Eisner, 1995, 2002; Bruner, 1988, 1997); Paivio, 1969, 1971, 1986; Sternberg, 2003,2006).

La postura sociohistórica, considera al aprendizaje desde el intercambio y la cooperación entre las personas, la asunción de riesgos, planteamiento de hipótesis, el contraste, la argumentación, el reconocimiento del otro y la aceptación de la diversidad, las TIC ofrecen una herramienta que facilita y amplía la comunicación entre las personas e instituciones geográficamente distantes, favoreciendo la construcción de significados colectivos (Rogoff, 1993, 2003; Vigotsky, 1991, 1934/1995).

El conocimiento está directamente relacionado con el entorno cultural donde tiene lugar, siendo las TIC elementos constitutivos de lo cotidiano. 


\subsubsection{Cognición distribuida}

Dentro del marco teórico vigotskiano, el ser humano sólo puede aprender o desarrollarse (términos que para Vigotsky refieren a dos planos de un mismo proceso: inter e intrapsicológico) y alcanzar funciones psicológicas de nivel superior en la medida en que haya una mediación cultural dada por la interacción tanto con otros agentes sociales como con herramientas culturales.

Los procesos de participación guiada se basan en la intersubjetividad. Las personas comparten propósitos y objetivos a alcanzar en entornos donde alguna de ellas resulta más hábil o capaz para resolver situaciones problemáticas, siendo guía de aquellas menos expertas. Son procesos de intercambio cognitivo, social y emocional. (Rogoff, 1993).

El aprendizaje está mediado por instrumentos o herramientas culturales; físicos o técnicos y signos, y por el rol que desempeña el tutor/mediador o facilitador de acceso al uso apropiado de las herramientas que la cultura provee (entre los que hoy se incluyen los dispositivos virtuales) (Vigotsky, 1934/1995)

Esta postura teórica es desarrollada por Edwin Hutchins (1990, 1995), a mediados de 1980, aborda los aspectos sociales de la cognición entrelazando miradas desde la Sociología, la Ciencia Cognitiva y el Sociohistoricismo. Sostiene que la cultura es el contexto de acción donde ocurre todo conocimiento. Toma de Lave (1991) el concepto de cultura construida en las prácticas cotidianas. El conocimiento es creado por la interacción de los seres humanos con los artefactos y con otros seres humanos. La actividad identificada como cognición implica desenvolverse en el mundo simbólico; las transformaciones simbólicas pueden observarse en el empleo de los artefactos culturales, como los diversos medios tecnológicos utilizados para el intercambio de conocimiento, entre ellos, las TIC. 
Cuando los sujetos resuelven situaciones problemáticas de la vida real, en relación con el entorno social y tecnológico, piensan en conjunción o en asociación con otros, y con la ayuda de las herramientas y medios que la cultura a la que pertenecen les proporciona (Salomom, G. op. cit.).

Las cogniciones deben concebirse como culturalmente mediadas, parte del conjunto de los sistemas de actividad que abarcan la cultura, la comunidad, las herramientas y sus contrapartidas autorregulatorias: los símbolos. Se encuentran distribuidas en el medio que es la cultura, por lo que la combinación de metas, herramientas y ambiente, constituye el contexto del comportamiento, al mismo tiempo que la forma en que está distribuida la cognición en el contexto (Cole y Engeström, 2001).

El modo en que la mente está distribuida, depende decisivamente de las herramientas mediante las cuales se interactúa con el mundo y éstas, a su vez, dependen de los objetivos de los sujetos. La combinación de objetivos, herramientas y contexto constituye el escenario del comportamiento y las maneras en que puede decirse que la cognición está distribuida en ese entorno.

Es un enfoque útil para re-diseñar los aspectos sociales de la cognición y poner el énfasis en el individuo y su entorno. Es un sistema de representaciones, y de modelos de intercambio de información entre representaciones que pueden tener lugar en el espacio mental de los participantes como en las representaciones disponibles en el medio ambiente. (González, A. op.cit.)

Los procesos cognitivos distribuidos pueden clasificarse en tres grupos:

- $\quad$ a través de los miembros de un grupo social; 
- $\quad$ en el sentido en que el funcionamiento del sistema cognitivo implica la coordinación entre estructuras internas y externas (materiales o medioambientales);

- a través del tiempo de tal manera que los productos de los acontecimientos anteriores pueden transformar la naturaleza de los eventos relacionados.

\subsubsection{Inteligencia distribuida}

La perspectiva de la inteligencia humana como distribuida ubica a ésta más allá del sujeto mismo, abarcando a otras personas, apoyándose en los medios simbólicos y aprovechando el entorno y los artefactos culturales. En palabras de Perkins (op.cit.), es la "persona-más" el entorno. Es decir, la persona puede mejorar su rendimiento, ampliar sus capacidades o ir más allá, lograr cambios en profundidad en sus procesos de comprensión. A las TIC que ofrecen una asociación o colaboración intelectual se las ha llamado "instrumentos cognitivos" o "tecnologías de la mente" porque potencialmente permiten a las personas pensar a un nivel que trasciende las limitaciones de su sistema cognitivo. (Batista, op.cit.).

Desde la postura sociohistórica, la interacción social se convierte en el motor del desarrollo. Vigotsky introduce el concepto de "Zona de Desarrollo Próximo" como la distancia entre el nivel real de desarrollo, determinada por la capacidad de un individuo de resolver independientemente un problema o tarea y el nivel de desarrollo potencial, a través de la resolución de un problema o tarea mediante la interacción de un facilitador o compañero más experimentado. (Bruner, op.cit.).

Pensar en los efectos cognitivos resultantes del trabajo con las TIC, implica referirnos a la "tecnología inteligente", definida por Salomon (op.cit.) como herramienta que asume parte de la carga intelectual de tratamiento de la información. 
Los efectos cognitivos derivados de la tecnología remiten al concepto de residuo cognitivo en tanto deviene del uso de las herramientas tecnológicas como socios intelectuales, transfiriendo a otras situaciones en las cuales utilice nuevamente la herramienta. (Casal, 2007)

Así, la perspectiva de la inteligencia distribuida, excede la noción de inteligencia como atributo individual, ejercida en transformaciones internas de las representaciones, objetos y relaciones. Las TIC son consideradas como un conjunto de herramientas con las cuales el sujeto interactúa de forma activa, formando una asociación intelectual que posibilita realizar tareas de forma más eficiente y en menos tiempo, pudiendo utilizarlas como "herramientas para pensar". (Batista, op.cit.)

La naturaleza humana, desde la visión de construcción histórico-social, considera la humanidad como "rehecha" a través de una dialéctica de influencias recíprocas: las actividades realizadas por los sujetos, productivas, modifican el mundo, cambiando así la forma en que el mundo modifica a los sujetos. Al dar forma a la naturaleza y al modo de mediación de las interacciones con ella, el sujeto se modifica a sí mismo.

El instrumento que el ser humano emplea para transformar sus condiciones de vida, y que lo transforma recíprocamente, está conformado por un artefacto y su modo de uso. (Azinián, op.cit.)

Las personas se encuentran participando de entornos construidos por artefactos inventados que son utilizados para estructurar la actividad, ahorrar trabajo mental o evitar la presencia del error.

Los cambios que derivan del uso de las tecnologías van volviéndose inadvertidos para quienes nacen con ellas, formando parte del entorno, considerándolas, naturales; tan natural como el accionar una llave y tener luz eléctrica en el ambiente.

Cuando las herramientas se tornan corrientes, por su uso frecuente y habitual, resulta más difícil considerarlas portadoras de inteligencia y se 39 
estima erróneamente como único portador de la inteligencia que resuelve la situación problemática, al sujeto que actúa, que emplea la herramienta.

La inteligencia puede estar distribuída también para su uso entre los artefactos diseñados por los sujetos, como las herramientas físicas, representaciones gráficas como diagramas y las interfaces entre las computadoras y su usuario para la resolución de tareas complejas. (Pea, 2001) Aquí la inteligencia se encuentra en el sujeto $y$ en la delegación de lo que podrían ser procesos de razonamiento mental complicados y propensos al error como limitaciones de la acción, ya sea del entorno físico como del simbólico.

La inteligencia cobra vida en el desarrollo de las actividades humanas; se pone de manifiesto en la relación medios y fines para lograr las realizaciones deseadas. La distribución implica dimensiones sociales y materiales. La primera deriva de su construcción en actividades como la participación guiada en la acción común compartida entre un padre y un hijo, del aprendizaje, o del trabajo cooperativo. La distribución material nace en la invención situada de usos de aspectos del entorno o del aprovechamiento de los "aportes" 9(funcionalidades) de los artefactos diseñados. Ambos pueden colaborar en el logro del objetivo de una actividad.

Para lograr la realización exitosa de una tarea, se trabaja sobre el supuesto de la interpretabilidad social de los "aportes" de los objetos: lograr que el sujeto atienda a las propiedades del entorno que son pertinentes, al objeto diseñado o a los rótulos, de modo de sumar su contribución a la inteligencia distribuída en la actividad.

\footnotetext{
${ }^{9}$ Son las propiedades percibidas y reales de un objeto, que determinan la manera como ese objeto podría utilizarse. Es el "para qué" de los objetos. 40
} 
Norman (1988) toma este concepto de "aporte" de los objetos, para describir cómo limita, muchas veces de manera innecesaria, la accesibilidad de éstos a los seres humanos. Desarrolla una "psicología de las cosas cotidianas", haciendo uso de las directrices del diseño y la funcionalidad de los objetos, mostrando como un diseño mejor formulado de los artefactos haría más sencillo el cumplimiento de determinadas funciones. De esta manera se lograría una "eficacia" de la acción del sujeto que es un objetivo tácito de la cognición en la práctica.

Formando parte de la actividad, el individuo que la realiza, suma como elemento de importancia, la interpretación de los recursos y las relaciones para el desarrollo de una actividad creativa y nueva.

El uso de la inteligencia distribuída en el entorno diseñado explícitamente para realizar una actividad, va más allá del determinismo situacional, de una decodificación de las intenciones (aportes) que se encuentran encerradas en el diseño de los objetos.

Los recursos con que contamos para realizar una tarea nos ofrecen relaciones potenciales, condicionadas por los "aportes", que pueden no estar mentalmente representadas antes de la percepción situacional del significado. La utilidad y funcionalidad de una herramienta, al igual que los elementos que configuran la inteligencia distribuída en una actividad humana sólo surgen en el transcurrir de las iniciativas de una persona, movidas por el deseo.

\subsubsection{Teoría Triárquica de la Inteligencia Humana}

Robert Sternberg (1990) desarrolla la teoría Triárquica de la Inteligencia Humana como modelo tridimensional para comprenderla. Resulta un 
marco conceptual valorable para la observación de los procesos cognitivos puestos en juego al interactuar en y con entornos tecnológicos.

Explica:

$>\quad$ el mundo interno de los sujetos y los procesos mentales que subyacen a la conducta inteligente;

$>\quad$ el papel mediador de las relaciones que a lo largo de la vida pueden establecerse entre el mundo interno y el mundo externo del individuo;

$>\quad$ la actividad mental en la vida diaria empleada en la resolución de los problemas que el entorno presenta.

Según esta concepción teórica, la inteligencia es la adaptación propositiva, la selección y el moldeamiento del entorno relevante del mundo real en la vida de un individuo; es teleológica, intencionada hacia el logro de metas o causas finales, por más que el sujeto no sea consciente de ello. Dicho de una forma sencilla: es el autogobierno mental. Dado que las personas debemos gestionarnos mentalmente a nosotros mismos, debemos ser inteligentes; no hay mayor problema con el término que utilicemos para identificarlo (Sternberg, 1990, 2003, 2003a, 2009, 2011). Todo lo que se precisa es capitalizar nuestros recursos y compensar nuestras debilidades.

Las subteorías que componen la Teoría Triárquica de la Inteligencia son:

\section{* Sub-teoría componencial (Inteligencia analítica)}

Describe la relación de la inteligencia con el mundo interno del individuo a través de los componentes o procesos mentales implicados en el pensamiento, que permite subdividir los problemas y encontrar soluciones no evidentes. Estos son de tres tipos: 
1) metacomponentes,

2) componentes de ejecución, y

3) componentes de adquisición del conocimiento.

Los metacomponentes, son los procesos ejecutivos usados para planificar, controlar y evaluar la solución de los problemas o tareas, e incluyen:

$>\quad$ definición del problema;

> $\quad$ selección de la estrategia apropiada para resolver el problema;

$>\quad$ representación mental de cómo los componentes y las estrategias pueden actuar;

> distribución de los recursos mentales adecuados;

$>\quad$ supervisión de las soluciones.

Comúnmente, la dificultad en la solución de un problema no se encuentra en el problema a resolver, sino en lograr una idea exacta de aquello que se necesita para resolverlo.

La selección de una estrategia que combine componentes de orden inferior constituye un aspecto muy importante de la inteligencia. Al posesionarse frente a los problemas, las personas eligen diferentes alternativas de solución en función de los conocimientos que poseen, el estilo cognitivo o las características de la tarea a resolver; así se utilizan estrategias holísticas o analíticas, espaciales o lingüísticas, etc.

La representación mental de la información permite comprender la situación problemática. Las personas utilizamos diversas representaciones (lingüísticas, espaciales, analogías, etc.) adecuadas a las circunstancias. La flexibilidad en el uso de las representaciones mentales es una característica de la inteligencia.

Los seres humanos disponemos de una variedad de representaciones mentales, y uno de los rasgos de la conducta inteligente es saber cuándo servirse de cada una de ellas. 
La distribución de los recursos mentales implica la regulación y uso intencional, incluyendo motivación, afectividad, conocimientos, atención, etc. Diferenciar lo importante de lo secundario, concentrar atención en lo relevante, dedicar el esfuerzo y tiempo justos, son algunos de los indicadores.

Los componentes de ejecución son los procesos de nivel más bajo de todos los procesos encargados en hacer efectivos (o ejecutar) los mandatos de los metacomponentes.

Mientras que el número de metacomponentes empleados en la realización de diversas tareas es relativamente limitado, el número de componentes de ejecución probablemente sea mayor.

Los componentes de ejecución de mayor interés son los que se extienden a diversas tareas cognitivas.

Sternberg identifica como componentes de ejecución los procesos de:

1. codificación,

2. inferencia,

3. funcionalización,

4. aplicación,

5. comparación,

6. justificación.

Los componentes de adquisición del conocimiento son aquellos procesos utilizados para aprender a solucionar los problemas; para optimizar el nivel de conocimientos a partir de la información que proporciona el contexto. Se utilizan para aprender cómo realizar lo que los metacomponentes y los componentes de ejecución efectúan.

Los componentes actúan conjuntamente. Los metacomponentes activan los componentes de ejecución y de adquisición de conocimientos. Estos últimos proporcionan, a su vez, una retroalimentación a los metacomponentes. Son altamente interdependientes e interactivos. 
La subteoría componencial especifica los procesos mentales propios de la actividad inteligente, y reclama para sí una validez universal.

Estos universales cognitivos son comunes a todas las personas, independientemente de que los contextos socioculturales puedan ser muy diversos.

\section{* Sub-teoría experiencial (Inteligencia creativa)}

Especifica los procesos que tienen lugar cuando los sujetos se enfrentan a situaciones relativamente novedosas en los diversos contextos a lo largo de su vida. Estudia la inteligencia creativa.

Considera dos tipos de procesos: aquellos que posibilitan enfrentarse a situaciones novedosas demandando respuestas creativas y originales; y los que implican automatización de los procesos mentales. Esta última se logra por la realización efectiva de una tarea múltiples veces, y una vez adquirida, implica poco o nada de un pensamiento reflexivo. Los procesos automatizados pueden ser ejecutados en paralelo con otros procesos similares.

El procesamiento automático de información es relativamente rápido, ejecutado en paralelo, casi no requiere esfuerzo, demanda mucha práctica para ser desarrollado, no está limitado por la capacidad de memoria a corto plazo, y la mayoría de las veces se lleva a cabo a nivel no consciente.

Por otro lado, el procesamiento controlado es comparativamente más lento, de naturaleza secuencial, requiere mayor esfuerzo cognitivo, está sometido a control consciente, limitado por la memoria a corto plazo, y requiere escaso o nulo entrenamiento.

Si las tareas más complejas pueden ejecutarse únicamente cuando se encuentran automatizados los procesos mentales implicados, una carencia en esta automatización provoca errores o dificultades en el procesamiento de la información y como resultado, un rendimiento inferior en la ejecución de la tarea o un comportamiento menos inteligente. 
Los sujetos que son intelectualmente más capaces, automatizan mejor las operaciones implicadas en el procesamiento de la información.

Obtener una automatización más eficiente en las tareas u operaciones libera atención adicional (recursos) para tratar tareas o situaciones nuevas y poner en juego un pensamiento creativo. Las personas creativas perciben conexiones que otras no advierten, analizan y evalúan las propias ideas y son capaces de apreciar sus propios méritos

Puede observarse que hay cierta relación recíproca entre la novedady la automatización: cuanto más eficiente es un individuo en las situaciones nuevas, más recursos cognitivos dejará liberados para la resolución de las otras situaciones. Paralelamente, a medida que aumenta la experiencia con nuevos tipos de tareas o situaciones, la novedad decrece y tendrá más recursos para la automatización.

Esta sub-teoría tiene una connotación universal con respecto a la importancia de la novedad y automatización como elementos relacionados con la inteligencia en toda sociedad y cultura. Al mismo tiempo es de carácter relativa, en cuanto que la novedad de situaciones y problemas, así como la automatización de procedimientos, ya que depende de los sujetos y grupos en sus contextos culturales respectivos.

Gracias a la intuición abordamos la novedady resolvemos problemas.

Según la sub-teoría experiencial, la intuición consiste en tres procesos estrechamente relacionados de:

1. codificación selectiva: se identifica la información pertinente y se descifran los datos esenciales;

2. combinación selectiva: se relacionan los elementos novedosos con la información ya conocida, y

3. comparación selectiva: se articulan las relaciones no evidentes u obvias entre la información existente y la nueva. 
Un problema es resuelto intuitivamente a nivel personal cuando se alcanza por primera vez la solución. A nivel social, un procedimiento o solución es creativo y original si hasta ese momento no estaba disponible para nadie.

\section{* Sub-teoría contextual (Inteligencia práctica)}

Estudia la inteligencia práctica puesta en juego al buscar un ajuste adecuado entre la persona y el contexto.

La inteligencia, cuando se aplica a la vida cotidiana, cumple tres funciones: la adaptación a los ambientes existentes, la selección de nuevos ambientes, y el moldeamiento de los actuales ambientes en nuevos.

Esta sub-teoría pone especial énfasis en la relación del sujeto con el entorno, analizando la conducta inteligente en un contexto dado.

Tiene carácter universal, dada la importancia de la adaptación, la transformación y la selección del medio ambiente para la supervivencia de los sujetos y de la especie. A su vez, es relativa a las culturas, ya que una conducta valorada como adaptada, selectiva o transformadora, varía según los contextos socioculturales.

Adaptación, transformación y selección son funciones del pensamiento inteligente actuando en los variados contextos a lo largo del ciclo vital.

Los modos de aplicación pueden diferir ampliamente entre individuos y grupos. La inteligencia no puede ser comprendida independientemente de las maneras como se manifiesta. 


\subsubsection{Modos de representación simbólica $y$}

resolución de problemas

Interactuar en entornos de tecnología digital destinados al aprendizaje, implica acceder a los conocimientos que nos presenta realizando construcciones mentales, representaciones de las estructuras conceptuales de un dominio de conocimiento, adquiridas y por adquirir, y de las orientaciones o consignas que permitan el análisis y estudio del tema.

Los teóricos cognitivistas sostienen que no aprehendemos el mundo directamente, sino que lo hacemos a partir de las representaciones que de ese mundo construimos en nuestras mentes. Nuestras acciones cognitivas se realizan mediante representaciones simbólicas.

Las construcciones mentales logradas mediante las representaciones simbólicas permiten organizar ideas, clarificar conceptos, identificar relaciones de jerarquías e interdependencia, integrar conocimiento, reconocer errores.

Una representación es cualquier notación, signo o conjunto de símbolos que representa algún objeto que es cierto aspecto del mundo exterior o del mundo interior de los sujetos (es decir, un objeto imaginario). La palabra "libro" o el icono de éste, son representaciones externas que permiten evocar el "objeto libro" en su ausencia.

Las representaciones mentales son representaciones internas. Son maneras de presentar en la mente el mundo externo.

Pueden distinguirse dos tipos de representaciones simbólicas: analógica y proposicional. Las representaciones proposicionales son consideradas como entidades discretas y abstractas que representan el contenido ideacional de la mente en una forma que no es específica de ningún lenguaje. La discrecionalidad significa que admiten más de una 
representación posible: una frase, un principio, un discurso, se representa de diferentes maneras en distintas personas; refiere a una construcción individual. Según los teóricos proposicionalistas este tipo de representación mental constituye un código universal básico a través del cual se realizan todas las actividades cognitivas.

Los contenidos de la mente se consideran entidades relacionadas a través de relaciones conceptuales.

La representación analógica prototípica es la imagen visual; hace referencia al uso de imágenes mentales, que mantienen las características de los objetos que representan; guardan una correspondencia no arbitraria con aquello que representan. También son consideradas como tales, aunque con menor frecuencia de uso, las auditivas, olfativas o táctiles. El perfume de una flor puede evocarse mediante una imagen olfativa, esto significa que internamente está representada por ésta. Las imágenes son representaciones mentales precisas, formas de "ver" los objetos, los fenómenos, a las que se recurre para recuperarlos, los detalles que resultan relevantes al individuo que las construyen.

La hipótesis dual propuesta por Paivio (1971, 1986) postula que las imágenes tienen identidad como un tipo separado de representación interna, tanto que pueden trasladarse y rotar mentalmente. Reconoce la existencia de dos sistemas diferentes de codificación y almacenamiento, uno verbal y otro visual.

Una postura alternativa, más flexible es la que postula Norman (1983), que aún siendo partidario de las representaciones proposicionales, muestra cierta incredulidad al hecho de que lo complejo de la información representada en la memoria pueda realizarse de modo exclusivo mediante redes semánticas o esquemas. Considera que utilizamos tanto imágenes como representaciones proposicionales, sin limitar al pensamiento humano exclusivamente al procesamiento de símbolos.

Jerome Bruner (1966, 1988, 1997, 2001) plantea que las personas utilizan tres formas distintas de representación: el modo inactivo, icónico y simbólico. El primero consiste en representar al mundo mediante la acción. 
La representación icónica consiste en imágenes o esquemas espaciales, independientes de la acción; manteniendo en alguna medida un parecido con lo representado. La elección de la imagen no es arbitraria. El modo simbólico utiliza un elemento representativo cuya forma no guarda relación o similitud con el objeto a representar, basada en la utilización del lenguaje verbal.

Los tres modos de representación son reflejo del desarrollo cognitivo y actúan paralelamente.

Desde la mirada sociohistórica, las representaciones simbólicas que realiza un sujeto no están desligadas del contexto en que se desenvuelve. La influencia de la cultura es la variable esencial que explica la conformación de la mente. Bruner (2001), influido por los postulados de Vigotsky considera que "el desarrollo de la mente siempre es desarrollo asistido desde el exterior".

En las situaciones de enseñanza, Bruner sostiene que es el docente quien debe presentar la información con la cual interactúa el estudiante en el modo de representación que favorezca la comprensión.

Teóricos como Van Dijk (1995) resaltan la relación que puede establecerse entre la información lingüística y la visual. Es posible describir una imagen por medio de un enunciado verbal; mediante la lectura de un fragmento de texto puede elaborarse una imagen mental del mismo. Esta es descripta como una habilidad propia de los escritores, para generar en los lectores las imágenes que previamente ellos debieron construir al idear su relato. De todos modos, cabe aclarar que la generación de imágenes mentales es un proceso individual, donde interaccionan tanto imágenes como emociones, sentimientos e información verbal. Parafraseando a Johnson Laird (1988), una imagen puede valer más que mil palabras, pero una proposición vale una infinidad de imágenes"; tantas como lectores haya.

Según Johnson-Laird, una representación mental proposicional es una representación que puede ser expresada verbalmente, no está formada por palabras. Entender una proposición es saber cómo sería el mundo si fuese verdadera. Las representaciones mentales proposicionales se interpretan y 
evalúan a través de los modelos mentales. Éstos son análogos estructurales del mundo; su configuración, y no su aspecto, corresponde a la estructura de la situación que representan; (...)"desempeñan un papel central y unificador en la representación de objetos, estados de hechos, secuencias de eventos, de la manera en que el mundo es y en las acciones sociales y psicológicas de la vida diaria. Permiten a los individuos hacer inferencias, entender fenómenos, decidir las actitudes a ser tomadas, controlar su ejecución y principalmente experimentar eventos" (JohnsonLaird, op.cit.).

Todo nuestro conocimiento del mundo dependería de nuestra capacidad de construir modelos mentales. Las restricciones para la construcción de esos modelos derivan de cómo concebimos la estructura del mundo, de las relaciones conceptuales que gobiernan la ontología de lo real y de la necesidad de mantener el sistema libre de contradicciones. Además de representar el mundo, los modelos representan situaciones no ambiguas, ya sean estas reales o imaginarias.

\subsubsection{Características de las herramientas digitales como potenciadoras cognitivas}

Diversas investigaciones dan cuenta de las mejoras en las capacidades intelectuales de sujetos que participaron en entornos diseñados explícitamente para apoyar el aprendizaje. Las concepciones de la escuela socio-histórica, son el fundamento teórico que justifica este diseño; como ya mencionáramos, sostienen que el desarrollo se produce como "internalización" de procesos cognitivos socialmente distribuidos en una zona de aprendizaje o de "desarrollo potencial", orientada hacia el rendimiento autónomo.

Incorporar las TIC como instrumentos cotidianos en la resolución de problemas, permite a las personas mejorar su rendimiento cognitivo, ampliar sus capacidades, lograr cambios en profundidad en sus procesos de comprensión. A las TIC que ofrecen una asociación o colaboración 51 
intelectual se las llama "instrumentos cognitivos" o "tecnologías de la mente" porque potencialmente permiten al estudiante pensar en un nivel que trasciende las limitaciones de su sistema cognitivo (Batista, op.cit.).

Una de las características de las TIC que ofrece una mayor potencialidad para modificar la forma en que aprendemos los humanos es la de conectividad $^{10}$, que permite el aprender con otros.

Las TIC forman parte de los procesos de comunicación, son soporte que almacenan numerosos datos de modo permanente, permitiendo su archivo de manera externa al sujeto. Así, las personas reducen los esfuerzos de memorización rutinaria quedando libres para operaciones de mayor nivel o exigencia. Resultan un vehículo para comunicar ideas, sentimientos y opiniones. Son un espacio donde el sujeto hace uso de diferentes sistemas de registro de representaciones mentales, apoyándose en el ordenador y la pantalla del monitor, por su característica multimedial.

La conectividad que caracteriza las TIC es entendida como la posibilidad que ofrecen los entornos para establecer redes de información $y$ comunicación con múltiples puntos de acceso. Modifica la interactividad entre el profesor y los alumnos, y entre los alumnos entre sí al trabajar en la resolución de una tarea. El trabajo colaborativo se potencia de forma totalmente nueva a partir de estas redes (Martín Ortega y Marchesi Ullastres, 2006).

Potencian las habilidades intelectuales ya que requieren que los usuarios realicen procesos de decodificación de la información representada simbólicamente (palabras, números, íconos), y permiten que las actividades difíciles de realizar, por lejanía física, distancia en el tiempo o complejidad, puedan resolverse de modo efectivo, y más sencillamente.

Desde una perspectiva sociohistórica, la enseñanza y el aprendizaje no comprenden sólo la exposición de saberes socialmente reconocidos y

${ }^{10}$ Ver tabla 2 de la pág. 32 de este mismo trabajo. 
construidos desde un pasado, sino la colaboración en el desarrollo de capacidades que permitan tener un acceso a la información existente, de modo de elaborarla, almacenarla y recuperarla cuando sea necesario. Las TIC son útiles herramientas como memorias externas.

La conectividad permite la co-construcción del conocimiento, y colabora en el desarrollo de los sujetos desde las relaciones interpersonales que pone en juego.

Esta característica de los ordenadores ofrece nuevas posibilidades para el trabajo grupal y colaborativo ya que facilita la diversificación, en cantidad y calidad de las intervenciones colaborativas de los sujetos que participan, sean aprendices o expertos.

El aprendizaje colaborativo es un proceso donde interactúan dos o más sujetos para construir aprendizaje, mediante la discusión, reflexión y toma de decisiones; no sólo comparten información, sino que trabajan con documentos conjuntos, participan de proyectos de interés común, facilitándose la solución de problemas y la toma de decisiones. Según Díaz Barriga y Morales Ramírez (2009) se caracteriza por la igualdad y mutualidad que debe tener cada sujeto en este proceso, entendida como la conexión, profundidad y bidireccionalidad que alcance la experiencia, en función de la distribución de responsabilidades, planificación conjunta e intercambio de roles; los recursos informáticos actúan como mediadores psicológicos, eliminando las barreras espacio y tiempo. Por su parte, Colvin y Mayer (2008) indican que las interacciones de los participantes pueden darse sincrónica (simultáneamente) o asincrónicamente, con metas y perspectivas compartidas, de modo de producir conocimiento, generar un producto, resolver un caso o problemas relevantes, o adquirir competencias previstas en un espacio instruccional.

Esta concepción de trabajo tiene sus raíces en las posturas socioculturales y destacan los intercambios comunicativos o discursivos y las características particulares de las interacciones derivadas del trabajo en 53 
conjunto (Díaz Barriga y Morales Ramírez, op.cit.). El conocimiento es una construcción activa y conjunta de significados, mediada por diferentes instrumentos psicológicos.

Las TIC resultan facilitadoras en la consecución de un aprendizaje colaborativo puesto que permiten: estimular la comunicación interpersonal; acceder a información y contenidos; realizar el seguimiento del progreso del participante de modo individual y colectivo; crear escenarios para la coevaluación y autoevaluación. Son instrumentos tecnológicos al servicio de los procesos de comunicación y gestión del conocimiento.

La co-construcción del conocimiento tiene lugar porque existe una mediación semiótica. Los diferentes sistemas de significación creados por el ser humano permiten dos procesos asociados, presentes en la construcción de conocimiento: la producción y la interpretación del sentido; una producción de significación interpretativa.

Desde la postura sociohistórica, se logra una construcción en común en el proceso de las actividades compartidas por los sujetos que interactúan, que se comunican mediante los sistemas de símbolos, en el marco de una colaboración social.

Quien colabora en la resolución de algún problema con otra persona, quien co-construye con ella, lo hace gracias a un código compartido que permite tres acciones posibilitadas por los lenguajes:

- representar el mundo,

- comunicarse con otros y

- $\quad$ regular la conducta propia y del otro.

Si bien todo código cumple esa función, no todos lo hacen de igual manera. Distintos códigos abren a variados aspectos de la realidad, por una parte y, permiten regular la conducta del otro, autorregular la propia, y comunicarnos de forma cualitativamente diferente. 
Las TIC permiten interactividad con la información y con los otros; las personas son responsables de actuar con los contenidos y con quienes se contactan según propio criterio, de necesidad o preferencia.

Según Martín Ortega y Marchesi Ullastres (op.cit.), al trabajar sobre las capacidades de gestión del propio aprendizaje, debe ponerse en claro cuáles son las metas trazadas. Este primer objetivo es prioritario ante la amplitud de información a la que se tiene acceso mediante el uso de las TIC. En función de este propósito se organizará el cómo, cuándo y con quiénes se abordarán los datos que se presentan con distintos niveles de profundidad, desde variadas miradas.

El usuario gestiona su propio conocimiento, de acuerdo a sus ritmos y posibilidades. Esto tiene injerencia en su percepción como agente que conoce. Este ajuste a su tiempo personal facilita una mejora en la competencia del tratamiento de datos, ya sea en una situación de aprendizaje intencional o en una simple lectura de la información para otro uso personal.

La conectividad e interactividad favorecen el trabajo en equipo. La conexión que las computadoras permiten con otros sujetos distantes en el espacio facilita el intercambio de opiniones, de posturas teóricas, en definitiva, la construcción social de conocimientos por medio de esfuerzos cooperativos dirigidos a metas que son compartidas, o de diálogos y discusión producto de las diferencias entre perspectivas.

Las TIC proveen entornos que facilitan la resolución de tareas de forma colaborativa, de trabajo cooperativo, donde usuarios más avanzados en los conocimientos de determinadas áreas o en el uso de las herramientas digitales proporcionan apoyo para que sus compañeros puedan realizar tareas más complejas que las que sus conocimientos y sus habilidades actuales les permitirían (Rogoff, 1993). 
Hung y Der- Thanq (op.cit.) observan las características de comunalidad y carácter situacional ${ }^{11} \mathrm{del}$ uso de las TIC, que refieren a intereses, problemas y conocimientos compartidos por los usuarios. Facilitan la proposición y resolución de situaciones problemáticas desde un trabajo colaborativo.

Los usuarios operan dentro de un mundo físico que utilizan como fuente de información y, como mencionamos anteriormente, como extensión del propio conocimiento y de los sistemas de razonamiento. Norman (op.cit.) sostiene que el hecho de que las conductas inteligentes resulten de la interacción con el mundo y de la mediación de los procesos cooperativos que se establecen con otras personas, permiten sostener que la inteligencia opera de modo distribuido.

Las TIC no son en sí mismas un código representacional nuevo, hacen uso de medios tradicionales (letras, íconos, números). Al valerse de ellos en forma integrada, con características particulares y en otro contexto, podrían suponer un cambio de tipo cualitativo de los procesos cognitivos de quien los emplea (Martín Ortega, op.cit.).

Los entornos apoyados por TIC, al presentar la información de modo multimedial, facilitan la construcción de diversas representaciones mentales de los contenidos; al decir de Eisner (op.cit.) facilitan el desarrollo de múltiples formas de "alfabetismo"12, de variados tipos de construcción e intercambio de significados. Las formas de pensamiento que los usuarios son capaces de utilizar están influidas por el tipo de experiencias, que a su vez, contribuyen a configurar las formas de inteligencia que tienen oportunidad de adquirir. El desarrollo cognitivo se ve afectado por las formas de representación de que disponen.

El instrumento cultural para comunicar, para interactuar con las personas incide el modo y el contenido del pensamiento. La capacidad de representar un concepto dentro de los límites y posibilidades de una

\footnotetext{
${ }^{11}$ Ver tabla 3 de la pág. 33 de este mismo trabajo.

12 Eisner (1994) considera al alfabetismo como la capacidad de decodificar o codificar el significado de cualquiera de las formas sociales a través de las cuales este se transmite, no sólo por la lectura y escritura convencionales.
} 
determinada forma de representación, pone al usuario a operar en el marco de sistema representacional seleccionado.

El contar con múltiples formas de representación para transmitir y compartir significados facilita y favorece la comunicación entre las personas. Eisner sostiene que los significados se transmiten por medio de las palabras escritas, las formas visuales organizadas, los sonidos pautados, el movimiento. En este sentido, interactuar con estas formas de significados, acceder a ellos en el sentido más amplio del término, implica "alfabetizarse".

La realización del potencial cognitivo de los usuarios se asocia con las oportunidades con que cuentan para emplear los diferentes modos de representaciones mentales o sistemas simbólicos para construir y compartir significados.

El conocimiento es dependiente del contexto, por lo que lo óptimo es que el aprendizaje ocurra en contextos relevantes. La construcción de ambientes ricos en recursos resulta adecuada cuando se contemplan las condiciones cotidianas en que las personas resuelven los problemas, en contextos significativos, facilitando la posterior transferencia. (Ausubel, 2002)

Las características de multimedialidad y dinamismo que ofrecen las TIC posibilitan y colaboran con la interacción simultánea o combinada de variados sistemas representacionales, enriqueciendo el conjunto de recursos presentados en la pantalla, contribuyendo con el desarrollo y puesta en práctica de diversas destrezas y habilidades cognitivas, según las necesidades o preferencias del usuario.

Los estilos y preferencias de aprendizaje de los sujetos pueden fortalecerse y mejorarse mediante determinados recursos y estrategias didácticas que implican distintos modos de representación simbólica (Tabla n 4) 
Tabla No 4 "Estilos de aprendizaje y representaciones simbólicas empleadas en estrategias didácticas para su fortalecimiento" Adaptado de Richard M. Felder and Barbara A. Solomon, North Carolina State University ${ }^{13}$

\begin{tabular}{|c|c|}
\hline $\begin{array}{c}\text { Estilos de aprendizaje y } \\
\text { preferencias }\end{array}$ & $\begin{array}{l}\text { Estrategias para fortalecer los } \\
\text { estilos de aprendizaje }\end{array}$ \\
\hline $\begin{array}{c}\text { Visual } \\
\text { Aprenden mejor de aquello } \\
\text { que ven: diagramas, } \\
\text { diagramas de flujo, líneas de } \\
\text { tiempo, películas y } \\
\text { demostraciones }\end{array}$ & $\begin{array}{l}\text { - } \quad \text { sumar diagramas a } \\
\text { explicaciones narradas. } \\
\text { • } \quad \text { organizar la redacción de los } \\
\text { textos de modo de ver los temas } \\
\text { principales, datos que ejemplifican y } \\
\text { conexiones entre ideas. } \\
\text { • utilizar organizadores visuales } \\
\text { (gráficos, símbolos, etc.) para } \\
\text { mostrar relaciones entre ideas y } \\
\text { conceptos. } \\
\text { • emplear códigos de colores } \\
\text { para ver las distintas categorías de } \\
\text { información. } \\
\text { - utilizar la visualización como } \\
\text { modo de estudiar y preparar } \\
\text { exámenes y recuperar la } \\
\text { información. }\end{array}$ \\
\hline $\begin{array}{c}\text { Verbal } \\
\text { Aprenden mejor leyendo, } \\
\text { escuchando palabras leídas, } \\
\text { participando en discusiones y } \\
\text { explicando a otros } \\
\text { estudiantes. }\end{array}$ & $\begin{array}{l}\text { • ofrecer conferencias y clases } \\
\text { tutoriales. } \\
\bullet \quad \text { realizar preguntas para que } \\
\text { se "escuche" más información acerca } \\
\text { del tema. } \\
\text { • leer libros de texto } \\
\text { extractando en notas no más del } \\
\text { 10\% del contenido. } \\
\bullet \quad \text { grabar las conferencias y } \\
\text { clases magistrales. } \\
\text { - reescribir notas y sumar } \\
\text { aquello que se haya omitido de la } \\
\text { grabación. } \\
\text { • recitar o resumir la } \\
\text { información. } \\
\bullet \quad \text { conversar acerca de lo } \\
\text { aprendido. Trabajar en grupos. }\end{array}$ \\
\hline
\end{tabular}

${ }^{13}$ www2.ncsu.edu/unigy/lockers/users/f/felder/public/ILSdir/styles.htm consultado 28 enero 2012 


\begin{tabular}{|c|c|}
\hline $\begin{array}{c}\text { Estilos de aprendizaje y } \\
\text { preferencias } \\
\text { (continuación) }\end{array}$ & $\begin{array}{l}\text { Estrategias para fortalecer los } \\
\text { estilos de aprendizaje }\end{array}$ \\
\hline $\begin{array}{c}\text { Activo/Táctil } \\
\text { Necesitan experimentar el } \\
\text { conocimiento a través de sus } \\
\text { acciones, "haciendo" o } \\
\text { involucrándose } \\
\text { personalmente. Prefieren la } \\
\text { instrucción con ritmo rápido y } \\
\text { los instructores que } \\
\text { mantienen las cosas en } \\
\text { movimiento. }\end{array}$ & $\begin{array}{l}\text { - utilizar todos los sentidos } \\
\text { posibles mientras se aprende. } \\
\text { - experimentar los conceptos } \\
\text { aprendidos, concurriendo a } \\
\text { laboratorios, exhibiciones, visitas, } \\
\text { etc. } \quad \text { resolver problemas tipo y } \\
\text { - preguntas claves. } \\
\text { estudiar en grupo. } \\
\text { leída o escuchar la información } \\
\text { con ejemplos concretos. } \\
\text { pensar cómo aplicar la } \\
\text { información presentada. } \\
\text { recitar mientras aprende. } \\
\text { de aprendizaje. } \\
\text { - utilizar tarjetas de memoria } \\
\text { con otras personas. } \\
\text { - enseñar el contenido a otras } \\
\text { personas. }\end{array}$ \\
\hline $\begin{array}{c}\text { Reflexivo } \\
\text { Comprenden mejor la } \\
\text { información cuando tienen } \\
\text { tiempo para reflexionar sobre } \\
\text { ella a su propio ritmo. }\end{array}$ & $\begin{array}{l}\text { - estudiar en un espacio } \\
\text { tranquilo. } \\
\text { deteniéndose periódicamente a } \\
\text { pensar en que se ha leído. } \\
\text { P no memorizar el contenido. } \\
\text { Pensar los temas importantes, y } \\
\text { cómo se relacionan las ideas. } \\
\text { - escribir resúmenes del } \\
\text { significado del material leído. }\end{array}$ \\
\hline $\begin{array}{c}\text { Facticos } \\
\text { Prefieren hechos concretos y } \\
\text { específicos, datos y una } \\
\text { experimentación detallada. }\end{array}$ & $\begin{array}{l}\text { - consultar a los docentes } \\
\text { cómo las ideas y conceptos se } \\
\text { aplican en la práctica. } \\
\text { - pedir ejemplos específicos. } \\
\text { ideas" paba ejemplos conencra de } \\
\text { el grupo de pares. } \\
\text { l pensar cómo fue construida } \\
\text { la teoría y hacer conexiones } \\
\text { específicas con el mundo real. }\end{array}$ \\
\hline
\end{tabular}




\begin{tabular}{|c|c|}
\hline $\begin{array}{c}\text { Estilos de aprendizaje y } \\
\text { preferencias } \\
\text { (continuación) }\end{array}$ & $\begin{array}{l}\text { Estrategias para fortalecer los } \\
\text { estilos de aprendizaje }\end{array}$ \\
\hline $\begin{array}{c}\text { Teórico } \\
\text { Aprenden más } \\
\text { confortablemente con ideas } \\
\text { abarcativas, amplias, con } \\
\text { símbolos y nuevos conceptos. }\end{array}$ & $\begin{array}{l}\text { - reflexionar acerca de los } \\
\text { conceptos, interpretaciones o teorías } \\
\text { más amplias que abarquen los datos } \\
\text { expuestos de modo aislado. } \\
\text { - destinar el tiempo necesario } \\
\text { para leer preguntas de evaluaciones } \\
\text { antes de responderlas, y revisar lo } \\
\text { respondido. } \\
\text { - buscar sistemas y patrones o } \\
\text { modelos para organizar hechos de } \\
\text { modo significativo para cada } \\
\text { estudiante. } \\
\text { - dedicar tiempo a analizar el } \\
\text { material a aprender. }\end{array}$ \\
\hline $\begin{array}{l}\text { Lineal (uso del hemisferio } \\
\text { izquierdo) } \\
\text { Los pensadores lineales } \\
\text { aprenden mejor con una } \\
\text { organización paso a paso, en } \\
\text { una progresión lógica y } \\
\text { ordenada. Pueden trabajar } \\
\text { con secciones del contenido, } \\
\text { sin una comprensión } \\
\text { completa del total del } \\
\text { material a trabajar. }\end{array}$ & $\begin{array}{l}\text { - } \quad \text { escoger cursos y docentes } \\
\text { "estructurados". } \\
\text { - dedicar tiempo extra-clases } \\
\text { para completar los temas faltantes } \\
\text { en las anotaciones. Consultar al } \\
\text { mismo docente o a compañeros de } \\
\text { curso. } \\
\text { - reescribir el contenido según } \\
\text { la propia lógica de comprensión del } \\
\text { contenido expuesto en la clase. } \\
\text { - describir el material. }\end{array}$ \\
\hline $\begin{array}{c}\text { Holístico (uso del hemisferio } \\
\text { derecho) } \\
\text { Los pensadores holísticos } \\
\text { pueden sentirse perdidos o } \\
\text { incapaces de resolver } \\
\text { problemas hasta no ver las } \\
\text { relaciones entre las ideas. } \\
\text { Necesitan dar sentido a los } \\
\text { detalles. Tienden a ser } \\
\text { creativos. }\end{array}$ & $\begin{array}{l}\text { • hacer una vista previa a los } \\
\text { subtítulos, resúmenes y glosarios } \\
\text { antes de leer un capítulo. } \\
\text { • } \quad \text { adentrarse en un tema a la } \\
\text { vez. } \quad \text { concentrar el estudio en un } \\
\text { curso. Estudiar los temas que } \\
\text { resulten dificultosos cuando se } \\
\text { cuente efectivamente con el tiempo } \\
\text { para su comprensión. } \\
\text { contenidos ya conocidos. Indicar } \\
\text { cómo se aplicará lo aprendido. } \\
\text { - } \quad \text { emplear mapas y } \\
\text { organizadores visuales para una } \\
\text { visión global del tema. }\end{array}$ \\
\hline
\end{tabular}


Diferentes contenidos a aprender, distintos grupos de pares, particularidades de los docentes o singulares momentos en la vida académica llevan a escoger ciertos estilos de aprendizajes. Es aconsejable facilitar el desarrollo del abanico de estilos, de modo que quien aprende, mediante un trabajo metacognitivo, decida, opte, por aquél que le resulte más eficaz y efectivo.

La hipermedia ${ }^{\mathbf{1 4}}$ identificada por Coll y Martí (op.cit.) como característica relacionada con la estructura de hipertexto al organizar los contenidos, posibilita poner en juego procesos cognitivos propios de las distintos tipos de inteligencias estudiadas por Sternberg.

La estructura hipertextual permite saltar de un punto a otro en un texto, a otro texto, a través de los enlaces o links. Una página Web o un artículo, puede ser visitado de diversas maneras mediante esos enlaces.

Los primeros acercamientos a la Red por parte de un usuario presentan un cambio en la forma corriente de visualizar y relacionar los contenidos. Las personas tratan de ajustarse a los cambios cognitivos que produce el efecto de "surfear o navegar" la red (adaptación); aplican en primera instancia, en mayor medida, la inteligencia práctica. De este modo se facilita la autonomía en el acceso a la información y su posterior uso. Muchas veces el lector busca un entorno virtual que lo haga sentirse "bien", por ejemplo ver imágenes acompañadas de sonidos, encontrar opiniones coincidentes con la propia, visitar lugares en diferentes partes del mundo. Otras veces los usuarios pueden encontrar azarosamente un nuevo sitio que cumple características similares a los que utiliza habitualmente pero que le permite mejorar ciertas funcionalidades y así, opta por seleccionar este nuevo espacio descartando el anterior.

El componente de adquisición del conocimiento descripto por Sternberg adquiere importancia dado que el lector necesita seleccionar la información útil de la irrelevante y dirigir la búsqueda hacia la realización de los objetivos. Los metacomponentes acompañan la planificación y supervisión

\footnotetext{
${ }^{14}$ Hay consenso general en que el término toma su nombre de la suma de dos palabras: hipertexto y multimedia, como una red hipertextual que incluye no sólo texto, sino también: imágenes, audio, vídeo, etc. (multimedia). Extraído de http://www.hipertexto.info/documentos/text_hipertex.htm 61
} 
de los resultados obtenidos en la búsqueda de la información (González, op.cit.).

Los procesos de insight son necesarios para establecer criterios en el acceso y selección de información (inteligencia creativa), a la hora de acceder a las páginas Web.

Los procesos de automatización logrados mediante la realización efectiva de una tarea múltiples veces liberan recursos cognitivos para enfrentar tareas o situaciones novedosas en un entorno digital.

Varias particularidades de las TIC facilitan el proceso de monitoreo cognitivo, es decir, de observar los propios estados y procesos cognitivos, para analizarlos y lograr un mejor y mayor control sobre ellos, buscando un actuar cognitivo mejorado. Flavell (1976) señala que "la metacognición se refiere al conocimiento que uno tiene sobre sus procesos o productos cognitivos o sobre cualquier cuestión relacionada con ellos, es decir, las propiedades de la información o los datos relevantes para el aprendizaje." Implica el control, orquestación y regulación subsecuente de dichos procesos. El proceso metacognitivo es fundamental en el planeamiento, resolución y evaluación de problemas, ejecutadas principalmente por la inteligencia "analítica" postulada por Sternberg.

Características destacadas que permiten estos procesos cognitivos son la posibilidad de:

- lectura intencional de los modos de navegación entre los contenidos mostrados y abordados mediante las TIC;

- retroalimentación ofrecida por la herramienta digital y por los distintos usuarios que interactúan simultáneamente;

- acceso, ejercitación, revisión y reelaboración de lo actuado por los usuarios los diferentes modos de representación de los contenidos. 


\section{Capítulo III}

\section{Las TIC como herramientas facilitadoras de la inclusión}

En el capítulo II se abordaron variables del sujeto relacionadas con el logro de la inclusión digital:

_la relación entre las TIC y la educación como espacio de adquisición y utilización de las habilidades necesarias para interactuar e intervenir en la SIC.

_marcos teóricos que estudian los procesos cognitivos implicados en el uso de herramientas digitales, propias de la SIC.

_características de la TIC como potenciadoras de los procesos cognitivos.

Corresponde considerar las variables del área tecnológica a fin de que las TIC resulten herramientas facilitadores de una propuesta educativa que propicie la inclusión de las personas con limitaciones funcionales.

Según el informe realizado por el Observatorio de la Fundación VODAFONE/CERMI (2011) las TIC se encuentran ligadas a los servicios y productos destinados a las personas con diversidad funcional $y$ resultan herramientas de importancia en el camino hacia la plena autonomía personal e inclusión plena. Las mejoras en las mismas pueden tener un efecto liberador en las vidas de este colectivo en situación de vulnerabilidad al ofrecerles nuevas oportunidades para aumentar su independencia, mejorar su movilidad y acceder a los productos y servicios que necesitan. Esto sólo redundará en beneficio de todas las personas si las tecnologías emergentes se diseñan para ser accesibles. Las nuevas fórmulas de intercambio de comunicación e información siguen cambiando radicalmente la forma en que los ciudadanos trabajan, aprenden, compran, y participan en asuntos de la 
comunidad, y por ello es crucial que las personas con limitaciones funcionales ${ }^{15}$ tengan igualdad de acceso a estas tecnologías (Fundación Vodafone, 2011)

El escenario complejo donde las tecnologías y aplicaciones tecnológicas tienen incidencia en las situaciones de dependencia, puede ser graficado de la siguiente manera (Fundación Vodafone, 2005) (Gráfica no 3)

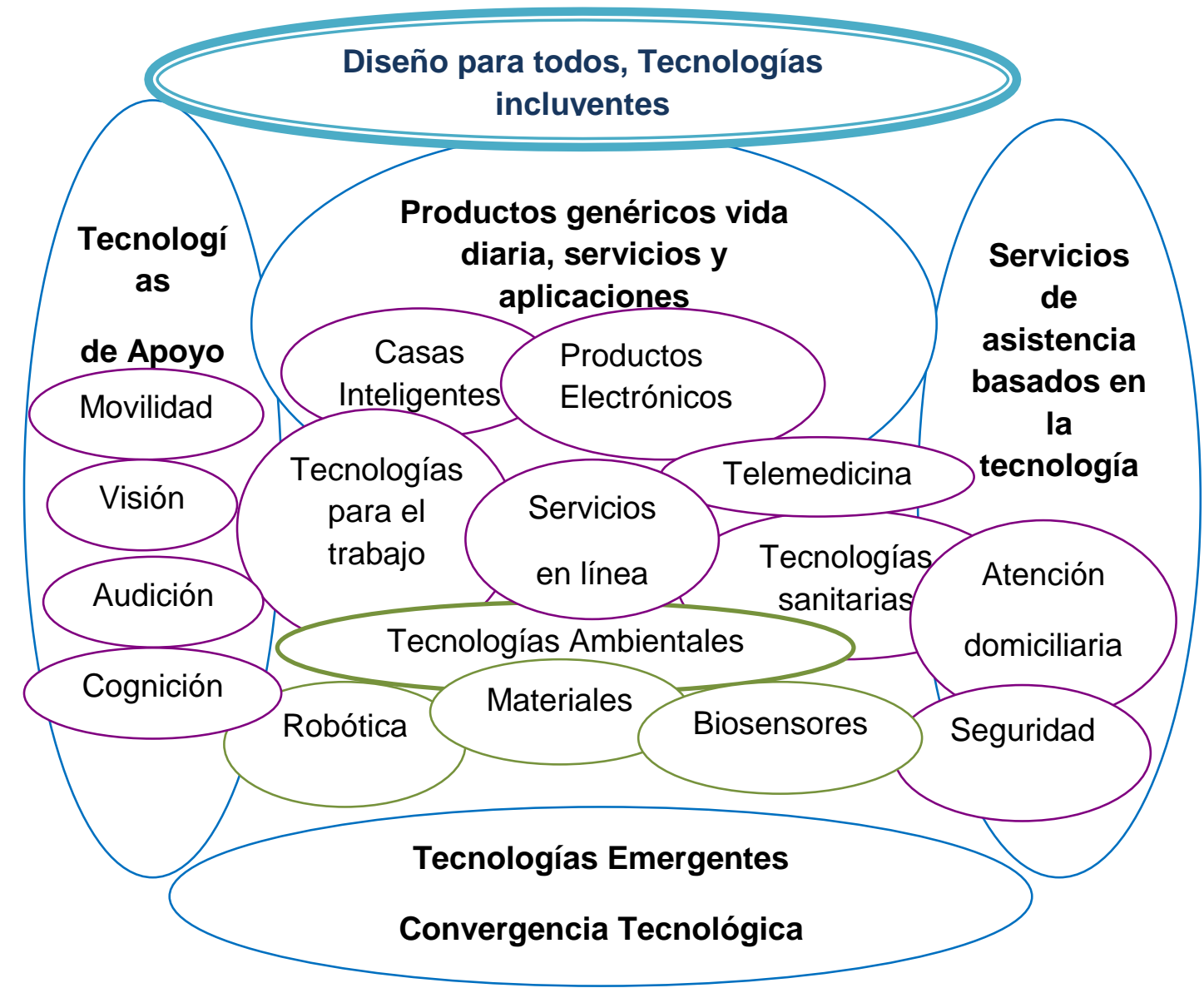

Gráfica No 3 "Áreas tecnológicas clave para la vida independiente". Adaptado de Cullen, WRT. Fundación Vodafone, informe 2005. www.observatorio.iti.upv.es

\footnotetext{
${ }^{15}$ Se entiende a la limitación funcional como la restricción o falta de habilidad para realizar una actividad, o función que es normal para una persona, según la edad, el sexo y los factores sociales y culturales.

64
} 
Para lograr que los desarrollos tecnológicos y la información digital planteen menores obstáculos para cualquier usuario, es necesaria la aplicación de los principios de accesibilidad, usabilidad, interoperabilidad y/o del Diseño para todos, propios del área tecnológica.

Pilares conceptuales de las propuestas de inclusión digital son: el Diseño Universal, la accesibilidad de y a las tecnologías de la información ( $e$ accesibilidad) y la competencia en el uso de estas (e-competencias), abordada en el capítulo II. Estos conceptos deben ser contemplados para todas aquellas tareas que involucren un usuario y su ordenador, sin limitarse a la navegación en la Red.

\subsection{Diseño Universal}

El término Diseño Universal fue acuñado por Ron Mace (1941-1998) para definir un tipo de diseño que permita a los usuarios sentirse cómodos en y con el uso de artefactos. El Center for Universal Design de la Universidad de North Carolina definió el Diseño Universal como "...el diseño de productos y entornos utilizables por todas las personas con el mayor alcance posible, sin necesidad de adaptación o diseño especializado. El intento del diseño universal es simplificar la vida de todos mediante la realización de productos, comunicaciones y la construcción de entornos más utilizables por tantas personas como sea posible con poco o ningún costo." (Center for Universal Design, 2005).

Es considerado un paradigma relativamente nuevo con alcance a todo el espectro de accesibilidad. De esta manera se supera la visión de tecnología asistida o de diseño accesible. 
También conocido como Diseño para todos, es la estrategia por la cual se conciben o proyectan, desde el origen y siempre que sea posible, entornos, procesos, bienes, productos, servicios, objetos, instrumentos, dispositivos o herramientas, de modo que puedan ser utilizados por el mayor número de personas, habida cuenta que existe una amplia variedad de habilidades humanas, sin necesidad de llevar a cabo una adaptación o diseño especializado, facilitando la vida de todas las personas independientemente de sus capacidades particulares ( edad, movilidad, o capacidad cognitiva).

Comprende no solamente al producto, sino su imagen, y la forma en que se vende el mismo, para que, además de ser accesible, capte el mayor número de consumidores.

El diseño inclusivo es lo suficientemente flexible para satisfacer las necesidades tanto de los usuarios principiantes como de los avanzados; es amigable para los usuarios en general, siendo más fácil de entender y utilizar.

Productos y sistemas con diseño inclusivo son más competitivos, con la creación de nuevas oportunidades de mercado y la forma de diferenciar los productos tradicionales similares; la atención se centra en la integración de las mejores soluciones para todos, con el apoyo de nuevas técnicas de investigación permitiendo diseñar centrando el proceso en el usuario.

Beneficia personas de todas las edades y habilidades. Supera la concepción de que los productos deben ser elaborados para sujetos "normales", considerados como estándares, representantes de la media de la población, para rescatar el concepto de la diversidad como característica distintiva de las personas y grupos. 
Los problemas de interacción con el entorno son debidos a la inadecuación de éste a las necesidades de los usuarios y no por el desajuste de las capacidades de éstos. Los productos son los que deben adaptarse a las necesidades de las personas.

Los principios que lo definen fueron compilados por: Bettye Rose Connell, Mike Jones, Ron Mace, Jim Mueller, Abir Mullick, Elaine Ostroff, Jon Sanford, Ed Steinfeld, Molly Story, y Gregg Vanderheiden (Mace, 2002) ${ }^{16}$

Sirven de guía en disciplinas del diseño, incluidas el ambiente, productos y comunicaciones entre los que encontramos a las TIC; son aplicables a requerimientos de diferentes usuarios, entre ellos, las personas con limitaciones en la visión que interactúan con TIC, objeto del presente trabajo (Tabla no 5).

\footnotetext{
${ }^{16}$ Compilado por defensores del diseño universal, listados en orden alfabético: Berrye Rose Connell, Mike Jones, Ron Mace, Jim Mueller, Abir Mullick, Elaine Ostroff, Jon Sanford, Ed. Steinfeld, Molly Story, and Gregg Vanderheiden, Instituto Nacional de Investigación sobre Discapacidad y Rehabilitación, Departamento de Educación , Estados Unidos de Norteamérica: en

http://www.design.ncsu.edu/cud/univ design/princ overview.htm
} 
Tabla No 5 "Siete principios del Diseño Universal". Adaptado de Center for Universal Design, $1997^{17}$

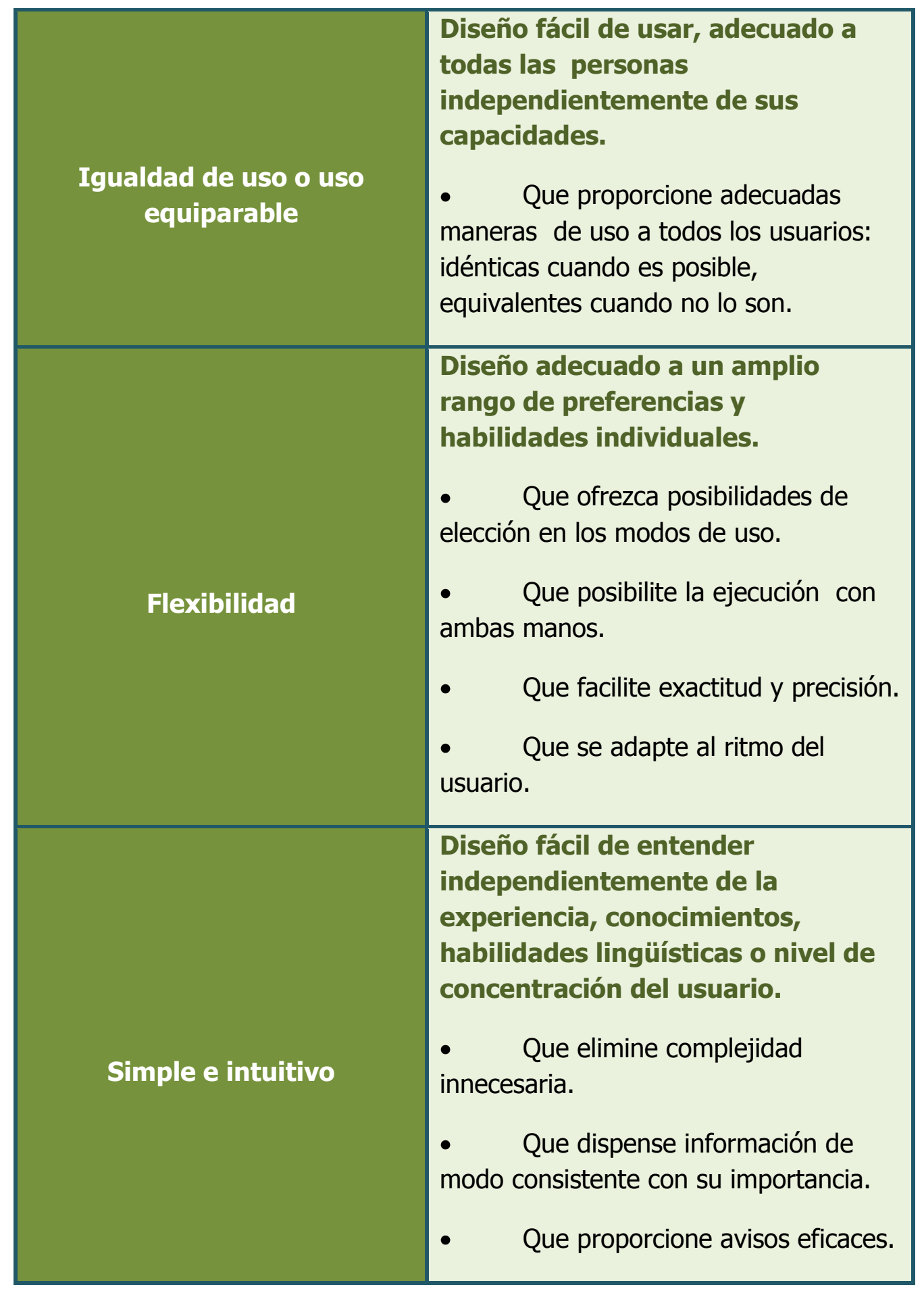

${ }^{17}$ Centro Para el Diseño Universal (NC State University, The Center for Universal Design, an initiative of the College of Design, 1997) 


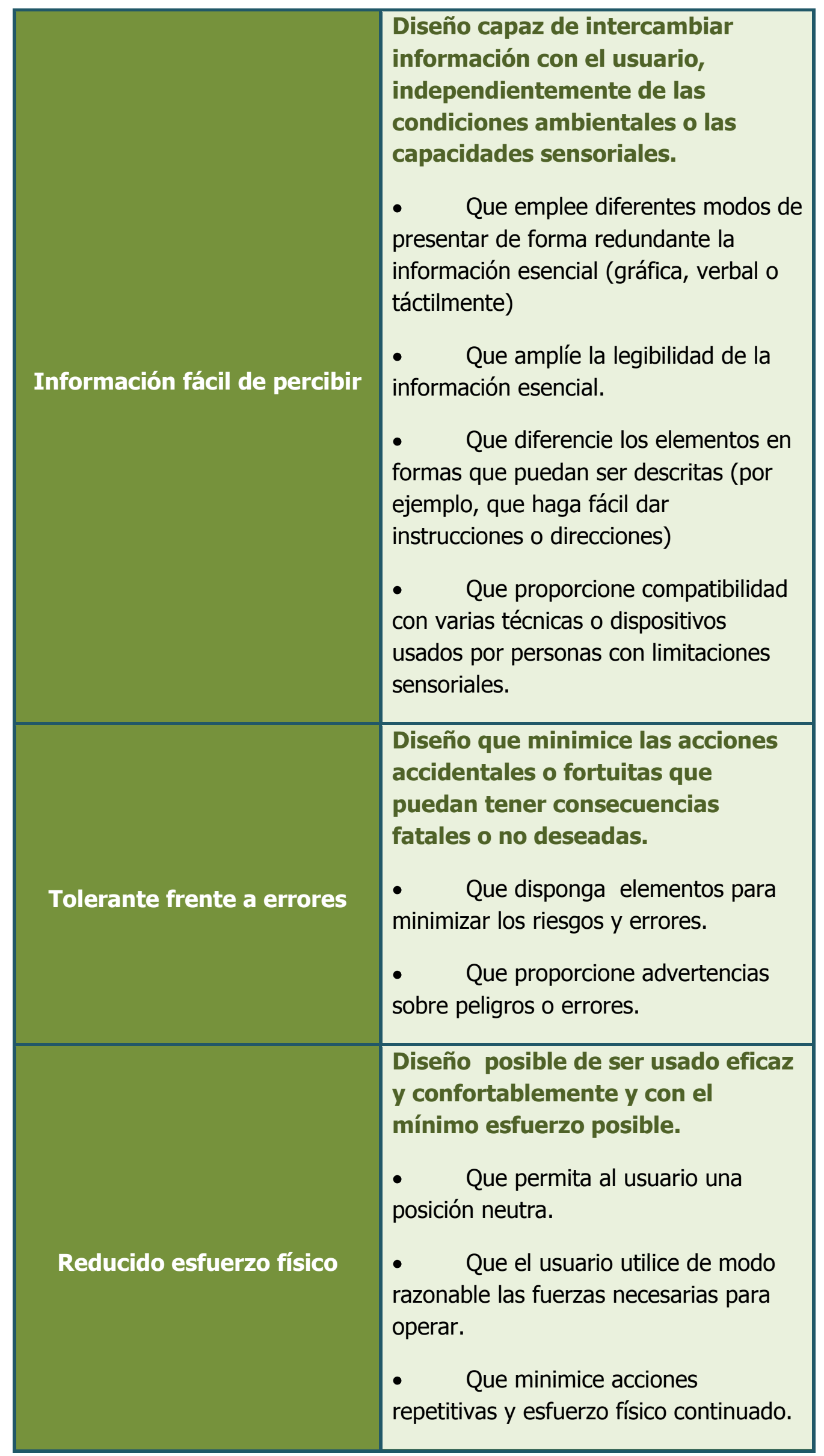




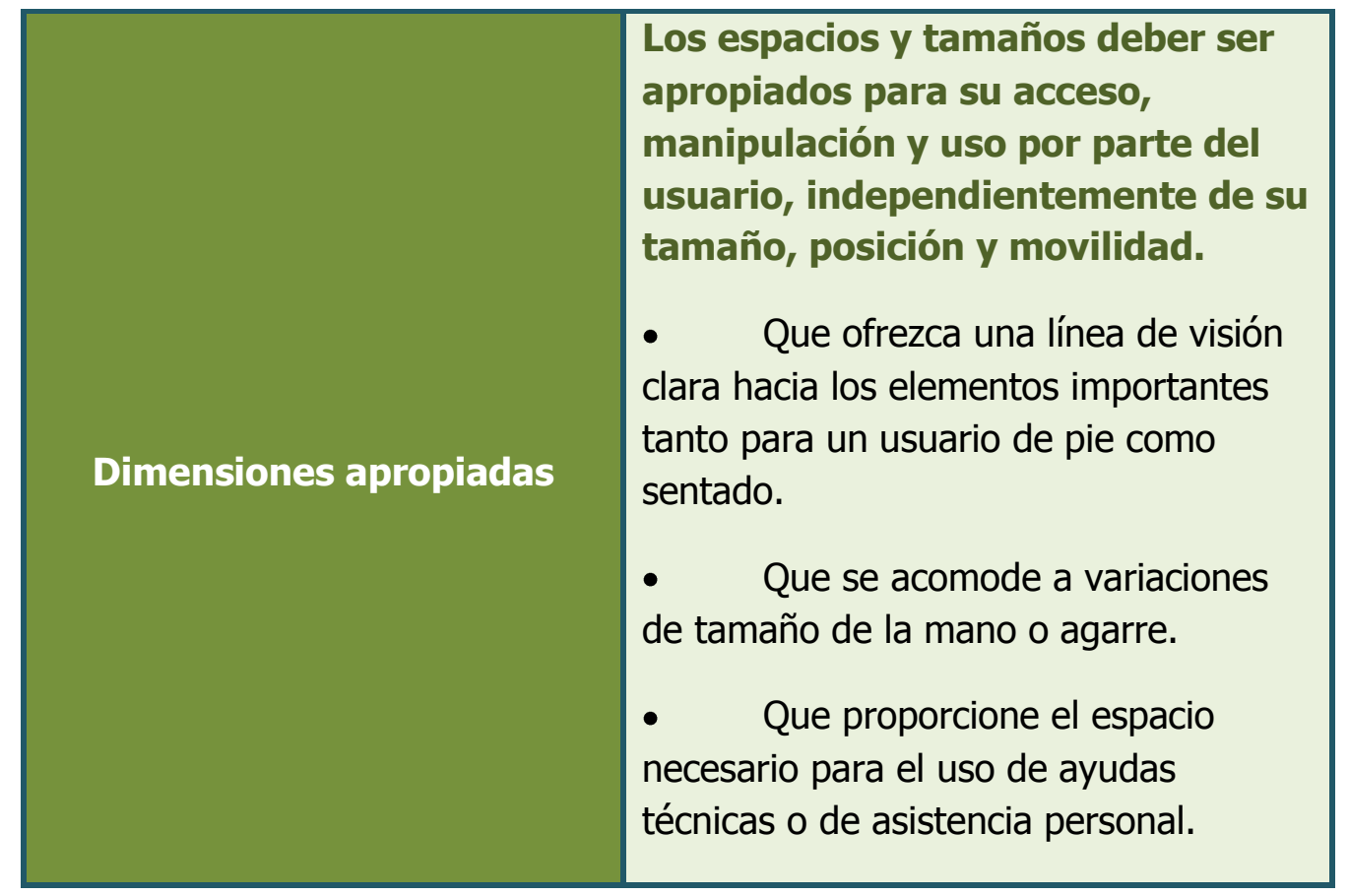

Estos principios hacen que el Diseño se transforme en parte de la solución, para la construcción de un entorno más inclusivo en el cual todas las personas tengan iguales oportunidades para la independencia, autonomía y participación ciudadana.

EL Diseño Universal considera la diversidad de habilidades y edades como realidad común del ser humano; esto demanda creatividad e inventiva por parte de los diseñadores que deben convertirse en compañeros/pares de los usuarios en una visión revitalizada del diseño como intrínseco a la sustentabilidad social. (Jean-Pierre Gonnot, 2007)

\subsection{Diseño para todos en entornos digitales}

En el campo de las TIC, se llama acceso universal a nociones de interoperabilidad, de compatibilidad, de equipamiento, de infraestructuras y 
de accesibilidad, también conocida como accesibilidad Web, sin acotarla al uso exclusivo del entorno de Internet.

El empleo del Diseño Universal o para todos (Mace et al., 2002), implica que las propuestas de desarrollo de TIC se caracterizan por evitar productos específicos para personas con una discapacidad particular. El software y/o el hardware se desarrollan desde un punto de vista ecológico, es decir, considerando las necesidades e intereses de todos los posibles usuarios. Esta iniciativa pone en primer plano al individuo, al usuario, y facilita su inclusión en los distintos ámbitos a los que pertenece: educativo, laboral, familiar, etc.

\subsection{La e-accesibilidad}

La accesibilidad al medio físico y comunicacional es un derecho a ejercer por los ciudadanos en igualdad de condiciones y con equiparación de oportunidades. Atraviesa las actividades cotidianas de todas las personas, y en particular, de las personas con diversidad funcional.

La "accesibilidad" es el grado en el que todas las personas pueden utilizar un objeto, visitar un lugar o hacer uso de un servicio, independientemente de sus capacidades técnicas o físicas. Permite participar de las actividades sociales y económicas para las que se conciben los entornos, por lo que, cuando se rompe la cadena de accesibilidad (llegar, entrar, usar, comunicarse, salir), por inobservancia o desconocimiento, deja de cumplirse con el derecho de las personas.

Hablar de accesibilidad, trasciende la referencia a rampas y escaleras, para adentrarse en el mundo de las TIC, cuya imposibilidad de acceso puede limitar más que la dificultad de moverse físicamente. Las TIC permiten que "sin moverse de casa" puedan realizarse variadas gestiones y tareas que de otra manera sería imposible llevar a cabo. (Pavón y Casanova, 2006) 
Promover la accesibilidad implica concebir los entornos, los espacios, haciendo uso de ciertas facilidades que ayudan a salvar obstáculos o barreras, consiguiendo que el mayor número de personas posible realicen la misma acción con el menor grado de dificultades.

La "accesibilidad" puede definirse como la condición a cumplimentar por los entornos, procesos, bienes y servicios, (entre ellos las TIC), de manera de resultar comprensibles, utilizables y practicables por las personas en condiciones de seguridad y comodidad, y de la forma más autónoma y natural posible.

Los desarrollos tecnológicos y la información digital, propios de la SIC, pueden plantear obstáculos graves o insalvables, cuando no se aplican los principios de accesibilidad y/o Diseño para todos.

En diferentes asociaciones gubernamentales y privadas en estos últimos años se está promocionando la e-accesibilidad, con el objetivo de asegurar que los diferentes grupos poblacionales, accedan a las TIC. Este nuevo concepto puede ser definido como la eliminación de las barreras que las distintas personas encuentran a la hora de acceder a los productos, servicios y aplicaciones de las TIC.

Referirse a accesibilidad web es remitirse a un acceso universal a la Web, independientemente del tipo de hardware, software, infraestructura de red, idioma, cultura, localización geográfica y capacidades de los usuarios.

Significa que una persona, utilizando un navegador sin características particulares puede visitar cualquier sitio Web y lograr el pleno entendimiento de la información contenida, como así también tener la habilidad de interactuar en el sitio sin enfrentarse con barreras tecnológicas. 
Considerar la e-accesibilidad al desarrollar un instrumento informático implica advertir las ventajas derivadas de esta forma de entender y construir el ciberespacio, entre las que podemos destacar:

- cumplir el derecho ciudadano a la participación y no discriminación por razón de discapacidad;

- respetar las disposiciones legislativas internacionales y nacionales al respecto.

- acrecentar el número de los usuarios potenciales, con mayor alcance de la comunicación, servicios o mercado.

- garantizar la equivalencia de los contenidos entre distintos navegadores y dispositivos, pues se diseña considerando estándares generales de accesibilidad.

- mejorar la indexación en los motores de búsqueda. El cumplimiento de las pautas, tanto en código como en contenidos semánticos (por ejemplo, vínculos con sentido) permite a los motores de búsqueda una mejor identificación de la información, y en consecuencia, mayores posibilidades de posicionamiento en los buscadores.

En relación a la interfaz que puede utilizar un usuario, siguiendo el principio de flexibilidad, debería tener contenidos configurables, controlables y comprensibles para todo usuario y compatibles con el dispositivo o aplicación que éste disponga para su utilización.

El World Wide Web Consortium ${ }^{18}$ (W3C, 2010) define la noción de acceso universal como la posibilidad para todos los individuos de acceder a los recursos en la Web, cualquiera sea el material o software, la infraestructura de red, lengua materna, cultura, localización geográfica, o aptitudes físicas o mentales. Argentina forma parte de este consorcio desde septiembre de

\footnotetext{
${ }^{18}$ W3C es un consorcio internacional e independiente que reúne a organizaciones gubernamentales, no gubernamentales y empresas, cuya finalidad es promover la evolución e interoperatividad de la Web para fomentar la accesibilidad (http://www.wec.es).
} 
2011, siendo la Oficina Nacional de Tecnologías de la Información (ONTI) el organismo a cargo de la representación, difusión y regulación locales de los estándares de la W3C.

Para cada una de las etapas de elaboración de una Web, se han establecido pautas que sirven de guía y referencia para desarrollarlas de manera accesible. Abordan desde las herramientas de autor, hasta los contenidos, pasando por las aplicaciones con las que los usuarios acceden. ${ }^{19}$ Resultan una referencia normativa técnica, no legal, pues ofrece al Webmaster un documento que lo guía en la forma de aplicarlas, y un listado de verificación para comprobar si realizó correctamente el trabajo.

Cada punto de verificación tiene asignado un nivel de prioridad:

- la prioridad 1 se aplica a los puntos de verificación que el desarrollador tiene que cumplir, pues de lo contrario, algunos grupos de personas no podrán acceder a la información.

- la prioridad 2 se refiere a los puntos que el desarrollador debe cumplir. De lo contrario, algunas personas encontrarán muchas dificultades para acceder a la información.

- la prioridad 3 verifica los puntos que el desarrollador puede cumplir o algunas personas encontrarán dificultades para acceder a la información.

Según se respeten estas pautas, se determina el grado de adecuación de la página Web, distinguiéndose tres niveles, de menor a mayor accesibilidad:

" $\mathrm{A}$ ", en caso de que cumpla los puntos de de prioridad 1;

"AA" para las prioridades 1 y 2 y

"AAA" que incluye las prioridades 1,2 y 3.

19 Directrices para las herramientas de Autor 1.0 - ATAG 1.0.Directrices para el contenido Web 1.0 - WCAG 1.0. Directrices para agentes de usuario 1.0 - UAAG 1.0. 
A partir del cumplimiento de uno de los tres niveles, puede colocarse en la página el distintivo homologado correspondiente en la Web, que notifica a los visitantes, el grado de adecuación a los criterios de accesibilidad.

\section{W3 WAI-A Conformidad nivel "A": Cumplen todos los puntos de verificación de prioridad WCAG 1.0 1 (debeni). \\ WB" WAI-AA $\mid$ Conformidad nivel "AA": Cumplen todos los puntos de verificación de WSC WCAG 1.0 prioridad 1 y 2 (deberían). \\ WBr WAI-AAA Conformidad nivel "AAA": Cumplen todos los puntos de verificación de WCAG 1.0 prioridad 1, 2 y 3 (pueden).}

En Argentina, el 3 de noviembre de 2010, el Senado Nacional aprobó por voto unánime la Ley de Accesibilidad de la Información de las páginas Web, Ley $26.653^{20}$. El marco legal que sirve de referencia es la Ley 26.378 (Convención Internacional sobre los Derechos de las Personas con Discapacidad) que trata en su Artículo 9 (sobre Accesibilidad) y el Artículo 21 (Sobre Libertad de expresión y de opinión y acceso a la información) por la cual el Estado Nacional se compromete a realizar las acciones necesarias para garantizar el acceso a la información y a la comunicación sin costo adicional a todas las personas incluyendo a las personas con discapacidad en igualdad de condiciones. A partir de septiembre de 2011, Argentina participa como miembro del W3C, representada por la Oficina Nacional de Tecnologías de Información (ONTI), dependiente de la Secretaría de Gabinete y Coordinación administrativa de la Jefatura de Gabinete de Ministros.

Mediante este marco legal queda explicito que los sitios Web de las entidades del Gobierno Nacional Argentino deben ajustarse a las Normas y Directrices del W3C, es decir, se considerarán accesibles los sitios web gubernamentales que cumplan con las prioridades 1 y 2 de las WCAG 1.0, es decir, que alcancen el nivel "AA". ${ }^{21}$ Asimismo, son normativas que se sugieren desde el Programa gubernamental para la Sociedad de

\footnotetext{
${ }^{21}$ http://www.jgm.gob.ar
} 
la Información $\mathrm{PSI}^{22}$, con la finalidad de diseñar e implementar políticas públicas y proyectos que posibiliten el acceso a las TIC del mayor número de ciudadanos. Es en esta línea de trabajo que se enmarca la propuesta de análisis y elaboración del documento de la presente tesis.

Otras directrices de accesibilidad, pueden consultarse en el protocolo NI $4^{23}$, que toma su nombre de las cuatro iniciales de los objetivos propuestos: Normalización, Investigación, Integración, Intercomunicación e Interactividad. Éste indica una serie de pautas de diseño de navegación fácil, destinadas a aportar soluciones principalmente para las personas con discapacidad intelectual.

Para validar la accesibilidad de las páginas Web, debe complementarse la utilización de métodos automáticos, mediante el empleo de herramientas como TAW Y Cynthia, con métodos manuales como la utilización de los programas HERA Y HERA-XP, y no por último menos importante, la consulta directa a los usuarios. De este modo pueden ser identificados y corregidos la mayor cantidad posible de problemas de accesibilidad.

\subsection{Usabilidad digital}

Considerando los principios de Diseño Universal en el desarrollo de una página electrónica, abordamos el concepto de accesibilidad, atentos a los elementos de diseño de los contenidos. Estos elementos no siempre se encuentran relacionados directamente con variables técnicas que afectan a la recepción de la información en determinada plataforma, navegador, o sistema de acceso.

Otra variable relacionada con la posibilidad de trabajo de los contenidos de una página Web es la "usabilidad" de la misma.

\footnotetext{
${ }^{22}$ http://www.atedis.gov.ar

${ }^{23} \mathrm{http}: / /$ www-ni4.org 
La usabilidad de un sistema informático puede definirse como la medida en la cual un producto puede ser utilizado por usuarios particulares, para conseguir objetivos específicos con efectividad, $y$ satisfacción en un contexto determinado. Implica un acercamiento al desarrollo de productos y servicios, incorporando la retroalimentación directa de los usuarios. De esta manera se logra reducir costos y crear artículos que satisfagan las necesidades de quien es beneficiario directo. Es un valor que supera al potencial o las posibilidades de uso de un producto.

Puede observarse en la práctica que la accesibilidad y la usabilidad se enlazan estrechamente. El diseño accesible es usable. Si se aplican correctamente las directrices de accesibilidad se obtendrá un diseño usable. Así mismo, el diseño usable tiene que ser accesible ya que se centra en las necesidades del usuario.

Mientras que la accesibilidad está dirigida a desarrollar una Web para el mayor número posible de personas, la usabilidad pretende satisfacer a los usuarios, a través de una Red más eficaz y eficiente. De esta manera, los objetivos de uno y otro criterio se fortalecen: los sitios accesibles son más usables y viceversa.

Los usuarios de la información presentada en una página Web, pueden ser adultos mayores, niños pequeños, personas con distintas capacidades, personas que utilizan ordenadores con hardware antiguo o software lentos, etc. por lo que es necesario observar fielmente las directrices de accesibilidad para cumplir con las potenciales exigencias planteadas por los diferentes los usuarios/clientes. 
La ISO $9241-11^{24}$ proporciona una definición en la que se mencionan las palabras claves de la usabilidad: eficiencia, eficacia y satisfacción. "La medida en la que un producto se puede usar por determinados usuarios para conseguir objetivos específicos con efectividad, eficiencia y satisfacción en un contexto de uso" (ISO 1998).

La efectividad del producto alude a la precisión y plenitud con las que las personas logran los objetivos especificados empleándolo. Vinculados con este concepto se encuentran:

la "facilidad de aprendizaje" del uso del sistema, es decir, el tiempo a invertir en aprender a interactuar con el entorno y si se requiere consulta frecuente a los mecanismos de ayudas,

$>\quad$ la tasa de errores $y$,

$>\quad$ la facilidad para ser recordado, y tener presente las funcionalidades y los procedimientos.

La satisfacción comprende la ausencia de incomodidad y la actitud positiva en el uso del producto. Es un factor subjetivo, que considerará cada usuario.

Los principios del Diseño Centrado en el Usuario son una reformulación de los principios de la Ergonomía Clásica y de ellos se derivan en general las guías de accesibilidad.

Según Jakob Nielsen (1993) la usabilidad es la cualidad de un sistema por la que resulta fácil de aprender, de utilizar, de recordar, tolerante frente a errores y subjetivamente placentero.

Cuatro ítems básicos a considerar al momento de definir un espacio virtual como "usable" son:

1. partir de una aproximación al usuario. Enfocarse en las personas que interactúan con el ordenador. Es prioritario conocer, entender y

${ }^{24}$ ISO - International Organization for Standardization www.iso.org 
trabajar con quienes representen usuarios actuales, efectivos, o potenciales del producto;

2. conocer el contexto de uso. Las personas utilizan los productos para incrementar su productividad. Un producto se considera fácil de aprender y usar evaluando el tiempo que toma el usuario para llevar a cabo su objetivo, el número de pasos que tiene que realizar, y el éxito en predecir la acción apropiada. Desarrollar productos usables implica entender los objetivos del usuario, conocer sus trabajos y tareas, para que el producto informático los automatice, modifique o embellezca;

3. satisfacer las necesidades del usuario. Relaciona productividad y calidad. El hardware y el software son las herramientas que permiten realizar trabajos de manera efectiva liberando tiempo y esfuerzo de quien lo utiliza.

4. evaluar la facilidad de uso de un producto mediante la palabra autorizada de los usuarios, no de los diseñadores y los desarrolladores.

$\mathrm{Si}$ al desarrollar un producto informático se contempla el principio de usabilidad, puede obtenerse una reducción de los costes.

$>\quad$ de producción de los productos informáticos. Los costes y tiempos de desarrollo totales pueden ser reducidos evitando la redefinición, minimizando el número de cambios posteriores requeridos por los diferentes usuarios. (parches)

$>\quad$ de mantenimiento y apoyo. Los sistemas fáciles de usar requieren un menor entrenamiento y soporte para el usuario, además de menos mantenimiento.

$>\quad$ de uso. Los sistemas que mejor se ajustan a las necesidades del usuario acrecientan la productividad y calidad de las acciones y decisiones. Al ser de empleo sencillo, reducen el esfuerzo cognitivo de las personas que lo utilizan y les permiten disponer de habilidades a emplear, en tareas no resueltas por el sistema informático. Los sistemas difíciles de ejecutar suponen pérdidas en los tiempos de uso y no son explotados en su totalidad, ya que la persona no logra comprender las características avanzadas del sistema. En algunos casos podrían no utilizarlo, desaprovechando el material informático. 
Krug (2006) realiza una "síntesis coloquial" de indicaciones sencillas referidas a la usabilidad para desarrollar una aplicación informática:

- $\quad$ nada importante debe estar a dos clicks de distancia.

- todos estamos relacionados a seis clicks de distancia.

- $\quad$ el lenguaje que debe hablarse es el de los usuarios.

- eliminar la mitad de las palabras de un texto, y luego, alternativamente la otra mitad, preguntándose si el texto continúa siendo entendible.

- omitir palabras innecesarias, que reducen el ruido de la página y hacen el sitio más práctico.

- $\quad$ reducir al mínimo o eliminar las instrucciones para "despejar" la página.

- los rótulos tienen que ser breves y específicos, por ejemplo: "búsqueda de libros", en lugar de "autor, título, editorial, etc."

- evitar la frustración de los usuarios, pues la competencia en Internet se encuentra a un click de distancia.

- emplear convenciones existentes, de todo tipo, pues favorecen la Web.

- $\quad$ si la interfaz funciona, "seguir con ésta".

La usabilidad considerada como un modelo de desarrollo de aplicaciones, sistemas y productos orientados al usuario, cumple un rol más importante que la arquitectura de información o la gestión de ésta. Permite un mayor grado de integración de la persona con la aplicación en cuestión, tanto en el proceso de diseño, como en el de implementación.

Las diferencias en los modos de aprendizaje que pueden observarse en los usuarios reflejan variantes que se distribuyen en un continuo, desde ligeras preferencias hasta profundas necesidades. En el diseño de una interfaz, es 80 
preciso considerar esta diversidad y ofrecer representaciones alternativas de la información clave para interactuar. Las más adecuadas se seleccionarán a partir de la evaluación de las preferencias, necesidades características de los usuarios y de las actividades a resolver. Es preciso aplicar el principio de usabilidad.

La forma más corriente, tradicional de trabajar con la información ha sido a través del texto impreso. Otras opciones artísticas, fotográficas, musicales, de vídeo, o animación, resultan una forma alternativa de comunicar ideas para ciertos individuos. Es preciso asumir esta diversidad ofreciendo múltiples opciones para la expresión y el trabajo dentro de la propuesta digital.

La usabilidad debe ser un principio considerado en todo momento, desde el comienzo del proceso de desarrollo hasta las últimas acciones antes de ofrecer el sistema, producto o servicio al público.

\section{El diseño accesible incrementa el nivel de usabilidad.}

La aplicación de los criterios de usabilidad y accesibilidad, tiene repercusión en las prácticas comerciales. Permiten que toda persona en la comunidad pueda participar en una actividad académica, laboral o recreativa, reduciendo la necesidad ( $\mathrm{y}$ por lo tanto el costo) de las adaptaciones especiales y reduciendo o eliminando el riesgo de quejas y posibles juicios legales, tanto para una institución privada como para el Estado.

Otro beneficio resultante de la aplicación del criterio de usabilidad, es una mejora en la calidad del producto: el diseño centrado en el usuario resulta en bienes de mayor calidad de uso, más competitivos en un mercado que demanda productos de empleo sencillo, y mayor rentabilidad.

Sitios Web muy accesibles aparecen en primer orden de clasificación de las páginas de los motores de búsqueda, ya que fueron desarrollados teniendo en cuenta factores de encontrabilidad ${ }^{25}$ y de posicionamiento ${ }^{26}$ (Camus,

${ }^{25}$ Encontrabilidad: capacidad de los contenidos para ser identificados a través de sistemas de búsqueda en Internet, de ser exhibidos cuando los usuarios busquen algunas de las palabras que contienen. 
2009). Esto permite ahorrar en gastos de mantenimiento de la red y proporcionar a las empresas que mantienen los sitios, acceso a una base de clientes de la que hasta el momento no se obtiene su máximo rendimiento.

Si bien el Diseño para todos requiere un esfuerzo adicional por parte del desarrollador, particularmente si se plantea cuando el producto ya está fabricado, una vez logrado, abre nuevas posibilidades en la mejora de la calidad de vida de numerosas personas.

\subsection{Interoperabilidad digital}

Sumada a las características de accesibilidad y usabilidad, las TIC deben observar el criterio de interoperabilidad, de modo de facilitar la participación de los usuarios en los entornos virtuales.

La interoperabilidad es la condición mediante la cual sistemas heterogéneos pueden intercambiar procesos o datos.

Es una propiedad que puede predicarse de sistemas de naturaleza muy diferente, como pueden ser los sistemas informáticos (en cuyo caso puede ser análoga a la idea de estándaro de neutralidad tecnológica) o los ferroviarios. Forma parte del campo semántico de la estandarización.

Wikipedia la define como la capacidad de un producto o un sistema, cuyas interfaces son totalmente conocidas, para funcionar con otros productos o sistemas existentes o futuros y eso sin restricción de acceso o de implementación.

\footnotetext{
${ }^{26}$ Posicionamiento: conjunto de acciones que permiten que un contenido sea indexado y luego aparezca dentro de los primeros resultados de búsqueda para una palabra determinada.

82
} 
En el campo de la Informática se considera a la interoperabilidad de la Web como una condición necesaria para que los usuarios (humanos o mecánicos) tengan acceso completo a la información disponible.

El Instituto de Ingenieros Eléctricos y Electrónicos (IEEE) define interoperabilidad como la habilidad de dos o más sistemas o componentes para intercambiar información y utilizar la información intercambiada.

Según el $\mathrm{DCMI}^{27}$ (2011) la interoperabilidad es la habilidad de diferentes tipos de ordenadores, redes, sistemas operativos y aplicaciones para que funcionen de modo conjunto de modo efectivo, sin necesidad de una comunicación previa, intercambiando información de manera útil y significativa.

Entre las iniciativas recientes más destacadas para dotar a la Web de interoperabilidad se encuentran: los servicios Web (Berners-Lee, 2009) y la Web semántica (Berners-Lee, 2004).

Los primeros son considerados como un conjunto de aplicaciones o tecnologías con capacidad para interoperar en la Web. Intercambian datos entre sí con el objetivo de ofrecer servicios como procedimientos remotos (W3C, 2011). Proporcionan mecanismos de comunicación estándares entre diferentes aplicaciones que interactúan entre sí para presentar información dinámica a las personas que hacen uso de los mismos. Para alcanzar la interoperabilidad y extensibilidad entre aplicaciones, es necesaria una arquitectura de referencia estándar.

La Web Semántica o Web 3.0 es una Web extendida, es la web de los datos. Se basa en la idea de sumar metadatos semánticos y ontológicos a la Word Wide Web, que describen el contenido, significado y relación de los datos. Proporciona una solución a los problemas de sobrecarga de información y heterogeneidad de fuentes de información, consecuencias del crecimiento de la Web. El objetivo es mejorar Internet, ampliando la interoperabilidad entre los sistemas informáticos, empleando "agentes

${ }^{27}$ Dublin Core Metadata Initiative www.dublincore.org 
inteligentes", es decir, programas que indagan, interpretan documentos, capturan y tratan la información sin el trabajo de operadores humanos. Los componentes de la Web Semántica son los metalenguajes o los estándares de representación XML, XML Schema, RDF, RDF Schema y OWL, que ayudan a convertir la Web en una infraestructura global en la que es posible compartir y reutilizar datos y documentos entre distintos tipos de usuarios.

El tercer entorno o ciberespacio es el entorno de ocurrencia de la interoperabilidad digital, de aplicación de las características de accesibilidad y usabilidad.

El ciberespacio es el espacio virtual donde interactúan los ordenadores y las redes informáticas. También conocido como tercer entorno, permite el tránsito, la navegación por parte de los usuarios de computadoras interconectadas. Es un medio artificial que necesita de las máquinas para poder ser (Royo, 2004); del diseño industrial y digital de artefactos para poder acceder y habitarlo. El diseño y la tecnología lo construyen, lo hacen posible. Está basado y sustentado en una concatenación de sistemas tecnológicos que deben funcionar correctamente para que el usuario pueda actuar en él. La interdependencia hombre/máquinas es una de las características más destacadas del tercer entorno (Etcheverría, 2004).

La interfaz es, por definición, el área de comunicación entre el hombre y la máquina (Royo, op.cit.). Se genera entre el ser humano y un artefacto virtual (herramientas del ciberespacio) o entre el hombre y un artefacto real. Se construye mediante el lenguaje (señales, textos, hipertextos, imágenes, pictogramas, sonidos, esquemas, etc.) que tiene que ser claro para orientar al usuario, comunicar un concepto y las posibilidades de acción que este tenga. El objetivo principal del diseño de la interfaz es que los artefactos digitales sean "usables". 


\section{Capítulo IV}

\section{Diversidad de Usuarios y Tecnologías}

\subsection{De los usuarios}

En el grupo de personas que conforman la SIC, podemos identificar sectores sociales vulnerables, sujetos de la brecha digital, dentro de los cuales encontramos las personas con diversidad funcional. Se calcula que alrededor del $15 \%$ de la población mundial tiene algún tipo de dificultad sensorial, motriz o cognitiva (1.000.000.000 de personas) (OMS, 2011) ${ }^{28}$. En Argentina, según la Encuesta Nacional de Personas con Discapacidad (ENDI), realizada en 2003, el porcentaje es del 7,1 (2.200.000 personas) ${ }^{29}$.

Abordar el uso de las TIC, nos pone ante el análisis de la distribución de un bien que involucra posibilidades de inclusión social.

En los últimos años, ha ido ganando consenso el "paradigma de apoyos", desde la filosofía de la normalización (Nirje, 1970, Wolfensberger, 1972), el movimiento basado en la comunidad (Bruininks, Meyers, Sigford y Lakin, 1981) y el énfasis en la calidad de vida (Schalock, 1996, 1997) que ha derivado en un cambio en la forma en que se consideran a las personas con diversidad funcional.

El cambio de paradigma implica pasar de centrar la atención en los déficits del individuo a la autodeterminación y la inclusión.

El principio que gana aceptación en las relaciones sociales es el de "autonomía personal", que sitúa a la persona con diversidad funcional en el lugar de ciudadano titular de derechos y obligaciones, que "consume"

\footnotetext{
${ }^{28} \mathrm{http}: / /$ www.who.int/research/es/ consultada en 28 diciembre 2011

${ }^{29}$ Argentina: $20.6 \%$ de los hogares albergan al menos a una persona con discapacidad 85
} 
servicios, donde sólo algunos están referidos al área de salud. Como ciudadano, ejerce un papel en la planificación y concreción de los mismos. El planteo es responder a la necesidad de generar condiciones en el contexto para una participación plena en los ámbitos sociales (educación, trabajo, ocio, familia, etc.) interviniendo sobre los factores sociales 0 ambientales que resulten obstaculizadores.

La discapacidad se redefine al construir espacios, entornos amigables y accesibles para todos. Los principios sobre los que se sustenta son los de solidaridad, respeto, individualidad y universalidad.

Para la construcción de entornos amigables, la estrategia empleada es la identificación y desarrollo de apoyos que permiten mejorar el accionar de las personas.

Los apoyos son recursos y estrategias cuyo objetivo es promover el desarrollo, la educación, los intereses y el bienestar personal de una persona que mejoran el funcionamiento individual (Luckasson, 2002).

Prestar apoyos posibilita la participación en actividades típicas de la vida en entornos convencionales, particularmente a aquellas personas que tienen alguna limitación sensorial, motriz o cognitiva.

Los apoyos permiten un ensamblaje entre las competencias personales y las demandas del entorno en la resolución de cualquier tarea. El actuar humano se potencia cuando la discrepancia persona-entorno se reduce y los resultados personales mejoran.

Ninguna persona necesitará todos los tipos de apoyos que están disponibles. Las necesidades de apoyo difieren tanto cuantitativa (en número) como cualitativamente (en naturaleza); tienen que ofrecerse de modo flexible. 
Son facilitadores que colaboran en mejoras en las relaciones personales, en independencia, en mayores oportunidades para contribuir a la sociedad, en aumento en la participación en contextos y actividades comunitarias, entre las que se encuentra la educación.

La calidad de vida puede conceptualizarse e implementarse mediante las ocho dimensiones fundamentales definidas por Schalock y Verdugo (2002), donde los apoyos resultan favorecedores. Las dimensiones son el conjunto de factores que constituyen el bienestar personal, y expresan la multidimensionalidad del concepto (Tabla $n^{\circ} 6$ ).

Tabla No 6 "Dimensiones e indicadores que conceptualizan el concepto de Calidad de Vida" Adaptado de Schalock y Verdugo, 2002.

\begin{tabular}{|c|c|}
\hline $\begin{array}{c}\text { Dimensiones de la } \\
\text { calidad de vida }\end{array}$ & Indicadores ejemplares \\
\hline Relaciones Interpersonales & Interacciones, relaciones \\
\hline Bienestar Emocional & Felicidad, satisfacción \\
\hline Bienestar Material & Empleo, posesiones \\
\hline Desarrollo Personal & Nivel educativo, competencia personal \\
\hline Bienestar Físico & Salud, estado nutricional \\
\hline Autodeterminación & Autonomía, elecciones, metas personales \\
\hline Inclusión Social & Participación comunitaria \\
\hline
\end{tabular}


Estudios internacionales (Schalock, 2007) han identificado tres factores contemplados en estas ocho dimensiones:

1. independencia. Desarrollo personal, autodeterminación;

2. participación social. Relaciones interpersonales, inclusión social y derechos;

3. bienestar. Bienestar emocional, físico y material.

La definición de "persona con diversidad funcional", es construida dentro de la visión basada en los Derechos Humanos o modelos sociales. Pone la mirada en la interacción entre una persona con discapacidad y su ambiente. Contempla el papel de una sociedad al definir, causar o mantener la discapacidad mediante actitudes o normas de accesibilidad que favorecen una mayoría en detrimento de una minoría. La Convención sobre los Derechos de las Personas con Discapacidad (UN, 2006) sostiene que la discapacidad es el resultado de la interacción entre la persona y su entorno; no radica en la persona como resultado de alguna deficiencia. Lo reconoce como un concepto en evolución y sostiene que la legislación tiene que adaptarse para incorporar los cambios que ocurran en la sociedad.

La introducción del término "diversidad funcional", sustituye otros como "discapacidad", "minusvalía" que poseen connotación negativa. Toma como referencia para acuñar el término, la Clasificación Internacional del funcionamiento, de la discapacidad y de la Salud (CIF) promovida por la Organización Mundial de la Salud en 2001.

Al referirnos a la diversidad funcional, consideramos a las sociedades intrínsecamente imperfectas; las que establecieron un modelo de perfección al que ningún miembro concreto de ellas tiene acceso, y que definieron la manera ideal de ser física, sensorial o psicológica de las personas, al igual que las reglas de funcionamiento social que las organizan (Foro de vida independiente, 2005). 
El término "diversidad funcional" es apropiado a una persona que actúa de manera diferente o diversa respecto de la mayoría de la sociedad. Considera la diferencia de la persona, o mejor aún, su singularidad.

La visibilidad de las personas con diversidad funcional adquirió resonancia en el público como resultado de las políticas de grupos de defensa de los derechos y del eco en los medios masivos de comunicación. Estos "nuevos ciudadanos" necesitan ser reconocidos como tales en los distintos ámbitos comunitarios y garantizar su acceso a los servicios públicos de salud, educación y bienestar social (Malbrán, op.cit.).

\subsection{De la tecnología}

El empleo de las TIC, enmarcadas en el paradigma referido a los apoyos, implica la puesta en práctica de los valores que éste promueve, utilizándolas como instrumentos sociales capaces de colaborar y mejorar la participación democrática y las vidas corrientes de las personas con diversidad funcional.

Nos encontramos participando de la conformación de un nuevo marco interpretativo que aborda la discapacidad-diversidad desde la concepción de la igualdad de oportunidades poniendo especial énfasis en el diseño universal, la accesibilidad y la eliminación de obstáculos como instrumento de inserción, integración, inclusión y normalización. En este nuevo marco, el acceso a la SIC es una condición básica en el proceso de igualdad de oportunidades (Soto Pérez, F. y Rodríguez Vázquez, J. 2004).

Tanto en el mundo físico, como en el tecnológico, se ha visto que los recursos accesibles son más fáciles y sencillos para ser utilizados por todos 89 
los usuarios, aún aquellos que no muestran limitaciones sensoriales, motrices y cognitivas.

Para las personas con diversidad funcional las TIC pueden ser un elemento decisivo que facilita sus condiciones de vida, constituyéndose en algunos casos en una de las pocas opciones para acceder a un curriculum educativo que de otra manera quedaría vedado; es decir permite un camino hacia la inclusión (Siles Rojas y Reyes Rebollo, 2001).

El uso de las tecnologías como medio para incrementar, mantener o mejorar las capacidades funcionales es un práctica común en el ámbito de la intervención para personas con discapacidad (Alcantud y Soto, 2003). En este contexto, se utilizan varios términos para definir el campo de actuación de la atención tecnológica a las personas con diversidad funcional: ayudas técnicas, tecnología asistiva, tecnología de apoyo, tecnología de la rehabilitación o tecnología de ayuda, entre otras. Aún cuando suelen utilizarse indistintamente, cada una de ellas tiene matices que las diferencian.

Las TIC pueden clasificarse, según los usos que las personas con diversidad funcional realizan en:

1. tecnología Exclusiva,

2. tecnología de Apoyo

3. y en tecnologías Invisibles, en un futuro, es decir, que resulten transparentes, imperceptibles al usarlas. Parafraseando a Donald Norman (1994) que la tecnología esté detrás y no delante de las tareas, consiguiendo que el espacio "usuario-TIC" no exista y llegar al ideal de su invisibilidad.

1. El "paradigma del artefacto" o "tecnología exclusiva" refiere a las TIC que han sido diseñadas para una discapacidad determinada, específica. La experiencia muestra que es recomendable evitar el uso del software exclusivo, que clasifica a los usuarios desde su dificultad para realizar algunas tareas. En varios países se desarrollan programas con "etiquetas", centrados en el paradigma del déficit. Tienen la ventaja de que son más 90 
sencillos, muestran el obstáculo de no modificarse a medida que lo necesita la persona; requiere la sustitución por otro/s más adecuados o similares, que cubran los requerimientos del usuario, a medida que se presentan.

2. Las ayudas técnicas o tecnologías de apoyo son las que permiten facilitar el acceso a los entornos de vida, manteniendo en vigencia la mirada de la "eliminación de barreras", con los ajustes que cada situación amerita.

Son utensilios, dispositivos, aparatos o adaptaciones, producto de la tecnología, que se utilizan para suplir movimientos o colaborar en las limitaciones funcionales de las personas con discapacidad. Son consideradas "herramientas para vivir" utilizadas por quienes no se desenvuelven con la capacidad física, sensorial o cognitiva corriente.

Comprendida en el concepto de tecnología de apoyo, la tecnología adaptativa abarca programas y dispositivos que permiten la interacción amigable del usuario con la computadora para superar las barreras a las que se enfrenta una persona debido a su discapacidad. (Sánchez Montoya, 2002)

3. En la concepción del Diseño Universal o Para todos (Mace, 2002), las propuestas de TIC se caracterizan por evitar el desarrollo de productos específicos para personas con una determinada discapacidad; los software y/o hardware se piensan desde un punto de vista ecológico, es decir, teniendo en cuenta las necesidades e intereses de todos los posibles usuarios. Esta iniciativa enfatiza la mirada desde el individuo, facilita la inclusión de las personas en los ámbitos académicos, sociales y laborales.

Aplicando los principios del Diseño para todos, no hay clasificación de los individuos ni de las herramientas digitales por deficiencias. Sigue los lineamientos del paradigma inclusivo de la autonomía personal, la puesta en práctica de los valores que lo cimentan.

Algunos autores (Roig Vila, R., 2007; Sánchez Montoya, 2006) ven en el paradigma de la "Inteligencia Ambiental" una evolución futura del concepto de Diseño para todos, ya que ofrece la posibilidad de que en el entorno cotidiano se halle inteligencia integrada que facilita la vida diaria. Supone 91 
ofrecer un entorno de convergencia tecnológica ubicua y con interfaces fáciles. Implica diseñar las TIC de tal forma que éstas tengan en cuenta la presencia de la persona y la situación en la que se encuentra, adaptándose y respondiendo a sus necesidades, costumbres y emociones (Tecnoneet, 2008).

De la Inteligencia Ambiental se destacan tres características: ubicuidad, que permite acompañar al usuario donde esté (hogar, escuela, medio de transporte, trabajo, en movimiento por la calle, etc.); invisibilidad posibilidad de pasar desapercibida en el medio físico e inteligencia capacidad para adaptarse a las preferencias y requerimientos de la persona que la utiliza. Se enfatiza la perspectiva humanista, antes que el común determinismo tecnológico. Estos desarrollos involucran a expertos de diversas áreas como psicología cognitiva, ergonomía, ingeniería de software, filología, inteligencia artificial.

\subsection{Herramientas digitales que colaboran en la inclusión de los usuarios}

A partir de los principios de accesibilidad universal, y la estrategia del Diseño para todos, aparecen medidas y recursos, que benefician a la sociedad en su conjunto, haciendo los medios de comunicación más accesibles a todos los ciudadanos (González Perea, 2008).

Variados son los motivos que justifican la utilización de los medios tecnológicos por las personas con diversidad funcional: posibilidades para superar dificultades específicas; apertura de los modelos y posibilidades de comunicación del sujeto con su entorno, al familiarizarse con su utilización, colaborar en la incorporación del sujeto a la sociedad del conocimiento y la inclusión sociolaboral (Cabero, 2002).

Las ventajas de la utilización de las herramientas digitales por los usuarios con diversidad funcional son numerosas y dependen del tipo de dificultad. Pueden enumerarse las siguientes: 
- Colaboran en la superación de limitaciones que presentan las dificultades cognitivas, sensoriales, y motrices.

- $\quad$ Estimulan la autonomía.

- $\quad$ Favorecen la comunicación sincrónica y asincrónica de alumnos y profesores.

- Respaldan un modelo de comunicación, y de formación, multisensorial.

- $\quad$ Propician una formación individualizada.

- $\quad$ Facilitan la inserción sociolaboral.

- $\quad$ Enriquecen momentos de ocio.

- $\quad$ Ahorran tiempo en la adquisición de habilidades y destrezas.

- $\quad$ Propician el acercamiento de los sujetos al mundo científico y cultural.

- $\quad$ Favorecen la disminución del sentido de fracaso académico y personal.

A la hora de analizar la problemática que nos ocupa debemos tener en cuenta:

- Que la utilización efectiva depende del tipo de dificultad: visual, auditiva, motriz, o cognitiva.

- Su integración no sólo depende del tipo de limitación, sino también del grado.

- Su empleo puede colaborar con el usuario desde el punto de vista del hardware (componente físico de los ordenadores: teclados, impresoras, monitores,...) y del software (componente lógico: programas informáticos, navegadores).

- Es posible tanto la adaptación de los medios convencionales, como la construcción de específicos.

Son diversos los tipos de dificultades que pueden afectar el acceso a las TIC. Puede variar la gravedad de las limitaciones, ser permanentes, temporarias o crónicas, de nacimiento o suceder en diferentes períodos a lo largo de la vida, y una misma persona puede presentar diversidad funcional 93 
por múltiples dificultades coincidentes. La Organización Mundial de la Salud publicó en 2001 una exhaustiva clasificación de las discapacidades (OMS 2001), la Clasificación Internacional del Funcionamiento, la Discapacidad y de la Salud, conocida como CIF. Es una clasificación de salud y de "aspectos relacionados con la salud", válida para todas las personas, aceptada como una de las clasificaciones sociales de las Naciones Unidas e incorpora Las Normas Uniformes para la Igualdad de Oportunidades para las Personas con Discapacidad ${ }^{30}$. En lo que se refiere a las TIC suelen agruparse en discapacidades sensoriales, cognitivas y motoras (Guenaga, 2007) (Tabla no 7).

Tabla no 7 "Descripción de tipos de discapacidades, limitaciones consecuentes y TIC pertinente para su mejora" Adaptado de María Luz Guenaga, Ander Barbier \& Andoni Eguíl Luz, 2007

\begin{tabular}{|c|c|c|c|}
\hline Discapacidad & $\begin{array}{l}\text { Limitaciones u } \\
\text { obstáculos de } \\
\text { usuarios }\end{array}$ & Soporte Digital & $\begin{array}{c}\text { Características } \\
\text { y modo de uso } \\
\text { de los } \\
\text { soportes }\end{array}$ \\
\hline $\begin{array}{l}\text { Sensorial } \\
\text { Auditiva }\end{array}$ & $\begin{array}{l}\text { En la comprensión y } \\
\text { distinción de sonidos } \\
\text { (hipoacusia), hasta } \\
\text { sordera, que dificultan la } \\
\text { comunicación }\end{array}$ & $\begin{array}{l}\text { Hardware amplificador de } \\
\text { sonido. Reconocedores de } \\
\text { voz. Convertidores de } \\
\text { textos en voz. }\end{array}$ & $\begin{array}{l}\text { Hardware que } \\
\text { amplía el } \\
\text { volumen del } \\
\text { ordenador } \\
\text { mediante } \\
\text { switch. } \\
\text { Software que } \\
\text { amplía el } \\
\text { volumen y que } \\
\text { convierte el } \\
\text { texto escrito en } \\
\text { sonido, de uso } \\
\text { individual } \\
\text { mezclando los } \\
\text { volúmenes } \\
\text { según } \\
\text { características } \\
\text { del usuario. }\end{array}$ \\
\hline
\end{tabular}

30 "Las Normas Uniformes sobre la Igualdad de Oportunidades para las Personas con Discapacidad", adoptadas por la Asamblea General de las Naciones Unidas en su 48 a sesión del 20 de diciembre de 1993 (Resolución 48/96. Nueva York. Departamento de Información Pública de Naciones Unidas, 1994). 


\begin{tabular}{|c|c|c|c|}
\hline $\begin{array}{c}\text { Sensorial } \\
\text { Visual }\end{array}$ & $\begin{array}{l}\text { En el acceso a las } \\
\text { interfaces gráficas, } \\
\text { basadas en ventanas, } \\
\text { iconos, imágenes, videos } \\
\text { y animaciones, por } \\
\text { problemas de baja visión, } \\
\text { ceguera parcial o total, } \\
\text { daltonismo, vista } \\
\text { cansada y cataratas, } \\
\text { entre otros. }\end{array}$ & $\begin{array}{l}\text { Software amplificadores } \\
\text { de tipografía de texto } \\
\text { (magnificador de } \\
\text { pantalla); lectores de } \\
\text { pantalla; de } \\
\text { reconocimiento de voz; } \\
\text { navegadores sólo texto. } \\
\text { Software y hardware } \\
\text { convertidores de texto en } \\
\text { impresión Braille }\end{array}$ & $\begin{array}{l}\text { Hardware y } \\
\text { software de uso } \\
\text { individual, } \\
\text { adecuando los } \\
\text { parámetros de } \\
\text { aquellos que son } \\
\text { comerciales; } \\
\text { instalando en el } \\
\text { ordenador } \\
\text { programas } \\
\text { (reconocimiento } \\
\text { de voz, } \\
\text { magnificadores } \\
\text { de texto o } \\
\text { impresión } \\
\text { Braille) } \\
\text { adecuados a la } \\
\text { condición visual } \\
\text { de cada sujeto. }\end{array}$ \\
\hline Motora & $\begin{array}{l}\text { En el acceso al } \\
\text { ordenador por dificultad } \\
\text { en uso de los periféricos } \\
\text { de entrada como los } \\
\text { teclados y/o mouse; en } \\
\text { el desplazamiento; en la } \\
\text { manipulación; en el } \\
\text { control postural; en la } \\
\text { comunicación, por tener } \\
\text { afectadas las } \\
\text { extremidades superiores. }\end{array}$ & $\begin{array}{l}\text { Software del sistema } \\
\text { operativo; de } \\
\text { programación; de } \\
\text { aplicación (mouse y } \\
\text { teclado virtual; opciones } \\
\text { de lectura por voz; } \\
\text { amplificadores en lupa; } \\
\text { filtros de teclado; } \\
\text { narradores y notificaciones } \\
\text { visuales). Hardware de } \\
\text { adaptación de teclados } \\
\text { (reducidos; ampliados; } \\
\text { programables para una } \\
\text { sola mano; con } \\
\text { distribución y disposición } \\
\text { de teclas diferente; con } \\
\text { mouse incorporado; por } \\
\text { pedales; de conceptos; } \\
\text { licornios; carcasa); de } \\
\text { adaptación de mouse } \\
\text { (controlado por teclas; por } \\
\text { laser; de barrido; } \\
\text { ergonómicos; } \\
\text { magnificados; por } \\
\text { pulsadores; sensores } \\
\text { ópticos; de boca; para } \\
\text { barbilla) }\end{array}$ & $\begin{array}{l}\text { Los teclados y } \\
\text { mouses } \\
\text { adaptados se } \\
\text { manejan con la } \\
\text { boca, o con los } \\
\text { pies, o con una } \\
\text { sola mano, o } \\
\text { con el puntero } \\
\text { correspondiente, } \\
\text { según el tipo de } \\
\text { adaptación que } \\
\text { presenten. }\end{array}$ \\
\hline
\end{tabular}




\begin{tabular}{|l|l|l|l|}
\hline & & $\begin{array}{l}\text { Hardware y } \\
\text { software de uso } \\
\text { individual, } \\
\text { adecuando los } \\
\text { parámetros de } \\
\text { aquellos que son } \\
\text { comerciales; } \\
\text { instalando en el } \\
\text { ordenador } \\
\text { programas } \\
\text { (reconocimiento } \\
\text { de voz, } \\
\text { mognitivanificadores } \\
\text { de texto, } \\
\text { En la comprensión } \\
\text { gráfica o escrita del } \\
\text { contenido publicado; en } \\
\text { la capacidad de } \\
\text { concentración, atención } \\
\text { y/o memoria; en las } \\
\text { formas de interacción y } \\
\text { empleo de los programas } \\
\text { informáticos complejos. }\end{array}$ & $\begin{array}{l}\text { Software lectores de } \\
\text { pantalla; magnificadores; } \\
\text { de reconocimiento de voz; } \\
\text { sistemas de comunicación } \\
\text { aumentativa, alternativa; } \\
\text { de imágenes e íconos. } \\
\text { Hardware de teclados } \\
\text { adaptados; pantalla táctil; } \\
\text { filtro de teclado. } \\
\text { aumentativo } \\
\text { alternativo) } \\
\text { adecuados a las } \\
\text { necesidades del } \\
\text { usuario; } \\
\text { instalando los } \\
\text { periféricos de } \\
\text { entrada y salida } \\
\text { requeridos. }\end{array}$ \\
\hline
\end{tabular}

\subsection{Tiflotecnología. Tecnología adaptada para las} dificultades visuales

Contrario a una creencia generalizada, las personas con limitaciones en la visión y ciegas utilizan computadoras corrientes, accesibles en el mercado, con sus respectivas aplicaciones comerciales.

Sólo es necesario adaptar la computadora a los requerimientos de cada usuario considerando su grado y tipo de visión.

Las personas con "limitaciones visuales" pueden presentar baja visión (disminución visual o visión subnormal) o ceguera. Implican problemáticas distintas. 
La baja visión, a su vez, puede estar provocada por una merma en la agudeza visual (calidad de visión), por un recorte en el campo visual (cantidad de visión), o ambos.

Según el momento de aparición, existen cegueras y deficiencias visuales de nacimiento y adquiridas, temprana o tardíamente, teniendo importancia el momento porque de ello dependerá el monto de experiencias visuales previas a la lesión.

Ciega es una persona que tiene visión cero o sólo tiene una mínima percepción de luz que impide su uso funcional ya que pueden ser capaces de distinguir entre luz y oscuridad, pero no la forma de los objetos. (Mon, 2006; González Perea y Alcaide Martín, op.cit.).

Muchos problemas visuales pueden prevenirse actuando de forma anticipada. De las investigaciones realizadas por el Centro de Tecnologías para la Salud y la Discapacidad del INTI (Instituto Nacional de Tecnología Industrial) ${ }^{31}$ surge que en Argentina:

- $\quad$ El 22 por ciento de las discapacidades consideradas en su conjunto son visuales, lo que representa a unos 600.000 argentinos.

- Hay 50.000 ciegos de los cuales el $80 \%$ podrían haberse evitado si se hubieran tomado medidas de prevención, diagnóstico y tratamiento oportunos.

${ }^{31}$ http://www.atedis.gov.ar/ consultado 29 enero 2012 
El término "tiflotecnología", del griego Tiflo (ciego), se incorpora al Diccionario de la Real Academia de la Lengua Española en 2008, donde se define como el "estudio de la adaptación de procedimientos y técnicas para su utilización por los ciegos"32. Esta tecnología de apoyo comprende el conjunto de técnicas, conocimientos y recursos encaminados a procurar a los ciegos y deficientes visuales los medios oportunos para la correcta utilización de la tecnología con el fin de favorecer su autonomía personal y plena integración social, laboral y educativa (ONCE, 2011).

Al hablar de medios tiflotécnicos debemos diferenciar entre los previstos para personas ciegas y los diseñados para personas con restos visuales. A veces los equipos y los programas que se utilizan son dispositivos estándar, en combinación o con la conexión de equipos específicos para personas con dificultades en la visión, tanto en hardware como en software general o específico.

Se denominan tiflotecnologías específicas a aquellos dispositivos creados para el uso exclusivo de usuarios ciegos o con dificultades en la visión; mientras que la tiflotecnología adaptada aquel hardware y software diseñados para que los usuarios con estas características puedan utilizar un equipo estándar (Córdoba, Cabero y Fernández 2007).

Según el nivel de especialización pueden agruparse en:

Adaptaciones de bajo nivel de especialización: se estructuran según el tipo de usuario, en tres subcategorías:

- $\quad$ Ampliación de imagen (útil únicamente para las personas con resto visual, disminuidos visuales)(Imagen $\mathrm{n}^{0} 1$ )

\footnotetext{
${ }^{32}$ http://buscon.rae.es/draeI/SrvltConsulta?TIPO BUS=3\&LEMA=tiflotecnología Consultado 03/01/2012 


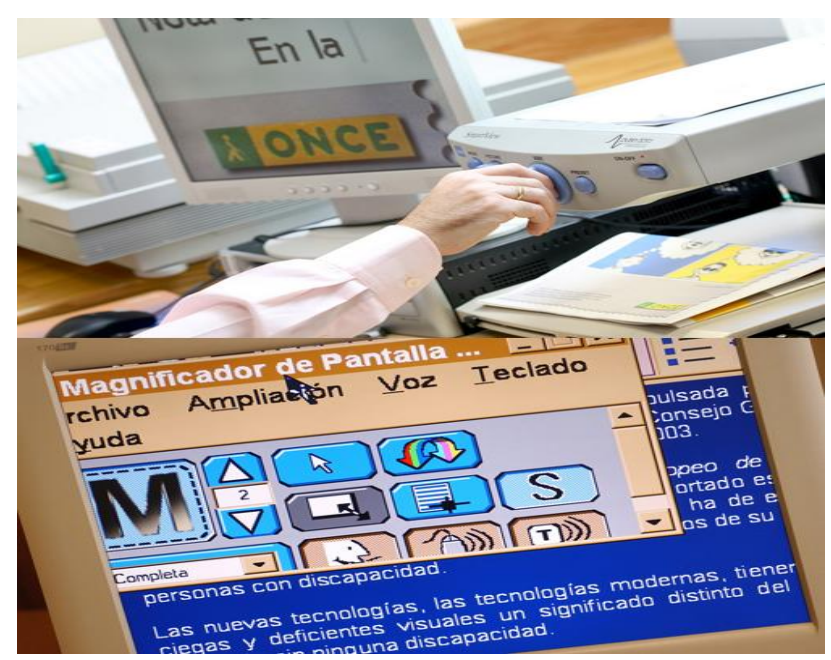

Imagen $\mathrm{n}^{01}$ "Magnificador de pantalla"33

- $\quad$ Síntesis de voz (para personas con poco resto visual y ciegos totales) Verbalizan la información de la pantalla del ordenador, tanto la que la persona va tecleando como la que aparece en la pantalla. Verbaliza además información adicional como, el color de los caracteres, negrita o subrayados, y permite regular la velocidad, tono y volumen del habla.

- $\quad$ Salida Braille (para los grupos de personas ya mencionadas, más las personas sordo ciegas y de retos múltiples) como la línea Braille, que es un sistema electrónico que permite el acceso a la lectura en Braille del texto que aparece en la pantalla de un ordenador o en otros aparatos informatizados, por medio de Braille efímero (Imagen n02) (va apareciendo una línea escrita, que desaparece cuando el usuario lee la segunda y así sucesivamente). Se incorpora como anexo del teclado convencional del ordenador y permite la aparición de puntos que van transcribiendo en Braille la información que aparece en la pantalla del ordenador.

\footnotetext{
${ }^{33}$ www.once.es
} 


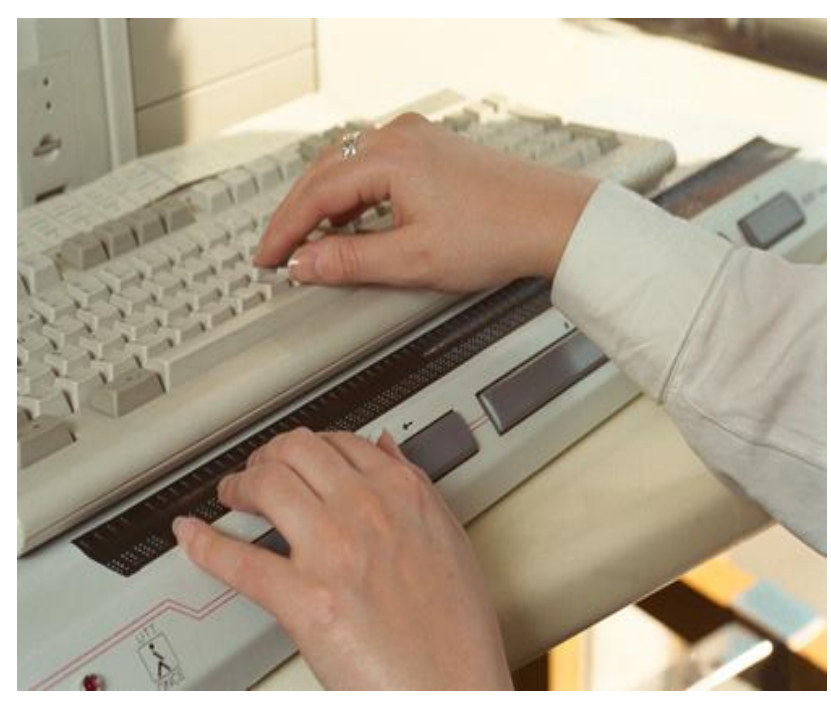

Imagen no 2 " Periferico Braille efímero"

Tabla No 8 "Resumen recursos tiflológicos de bajo nivel de especialización"

\begin{tabular}{|c|c|}
\hline $\begin{array}{c}\text { Adaptaciones tiflológicas de } \\
\text { bajo nivel de especialización }\end{array}$ & Características de usuarios \\
\hline Ampliación de imagen & $\begin{array}{c}\text { Personas con resto visual en } \\
\text { distinto grado }\end{array}$ \\
\hline Síntesis de voz & $\begin{array}{c}\text { Personas con poco resto visual } \\
\text { y ciegos totales }\end{array}$ \\
\hline Salida Braille & $\begin{array}{r}\text { Personas con resto visual, } \\
\text { sordociegos y personas con } \\
\text { multidiscapacidad }\end{array}$ \\
\hline
\end{tabular}

Adaptaciones de alto nivel de especialización: son aquellas aplicaciones cuyos resultados se obtienen del empleo de una o más de las adaptaciones de bajo nivel. Requieren la presencia de alguna de éstas y un entrenamiento previo del usuario para su correcto manejo. 
1) Revisores de pantalla compuestos por programas y controladores que toman información de la tarjeta de video del ordenador, y que luego de un proceso de análisis, suposición artificial y descifrado la transmiten al usuario. Estos son:

* amplificadores de caracteres: programas que tratan de aprovechar el resto visual de las personas con baja visión. Permiten ampliar el tamaño de las letras hasta 16 veces (diez caracteres en pantalla simultáneamente), cambiar los colores, realizar el seguimiento del cursor, cambiar las fuentes y crear nuevas, ampliar toda la pantalla o sólo una región (una cuarta parte, una línea seleccionada, etc.), lectura con desplazamiento automático de texto, etc. Tienen relevancia las funciones de seguimiento de «foco», y la presentación de diferentes tipos de «puntero» para lograr un buen seguimiento de los eventos y su distribución en pantalla. Con el fin de evitar excesivos esfuerzos visuales cuando no sea estrictamente necesario, estos programas utilizan otros canales de información complementarios. Actualmente casi todos los programas utilizan de forma alternativa o complementaria las posibilidades que ofrece la síntesis de voz. Los software que pueden encontrarse en el mercado son Lunar Supernova, MAGic, Zoomtext Xtra, entre otros.

* lectores de pantalla: son los programas que sirven de interfaz entre la tarjeta de video, los sistemas de síntesis de voz y/o los terminales de lectura Braille, y el usuario, que esperan lograr la lectura o interpretación del máximo posible de elementos que conforman las pantallas de cada entorno de trabajo.

2) Revisores de documentos aplicaciones que buscan la información para transmitir al usuario desde archivos informáticos localizados en un disco, ordenador remoto $u$ otro soporte similar, o bien en un periférico que la transmita mediante un proceso de conversión o identificación, haciendo uso de las aplicaciones de bajo nivel de especialización. Dentro de éstos encontramos:

* lectores de documentos: programas llamados de texto hablado, cuyo objetivo es la transmisión por voz del contenido de archivos de texto, creación de mensajes con voz sintética o simulación de 101 
canciones. Algunas de estas herramientas incluyen opciones de ampliación del tamaño de los caracteres, colocación de marcas de localización de secciones o puntos concretos, ajustes del color, fuente, etc. para facilitar la lectura.

* reconocedores ópticos de caracteres: se conocen bajo la denominación de Reconocimiento Óptico de Caracteres (OCR) o Reconocimiento Inteligente de Caracteres (ICR); son programas capaces de interpretar y reconocer la digitalización de un documento realizada por un escáner, presentándola en un periférico: pantalla, impresora, síntesis de voz, línea Braille, etc. Esta digitalización puede compararse a una fotografía del documento original que un ordenador puede reconocer. ${ }^{34}$

* Lupa TV: sistema de ampliación de imágenes consistente en cámara CCD conectada a un monitor Los textos a ampliar se colocan sobre una mesa de lectura de estructura $X Y$, pudiéndose conseguir una ampliación lineal sobre la mesa hasta 60 veces según el modelo y tipo de monitor utilizado. Permite detectar sin alteraciones el color del documento, permitiendo trabajar posteriormente con las combinaciones de los tres primarios. Esta característica aumenta el rango de posibilidades de trabajo, haciendo posible la conversión de documentos en blanco y negro a color y viceversa.

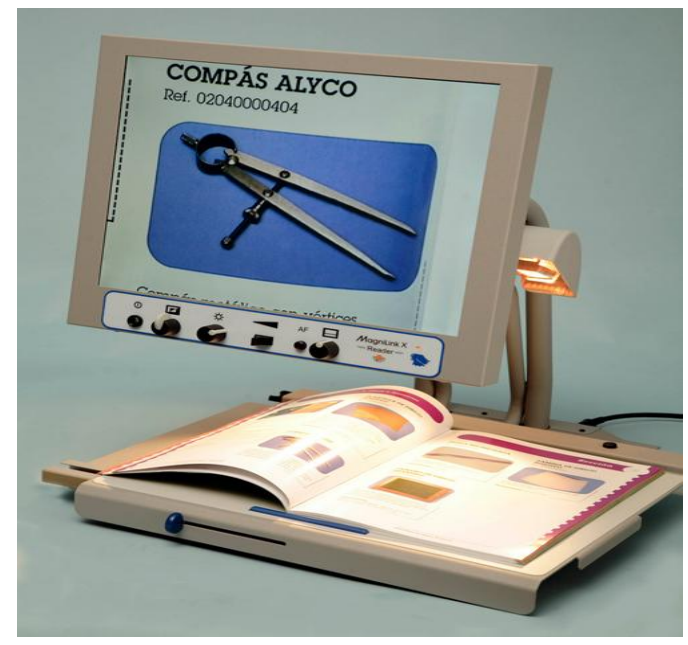

Imagen no 3 " Lupa TV"

${ }^{34}$ Para ampliar consultas visitar http://es.wikipedia.org/wiki/Reconocimiento \%C3\%B3ptico de caracteres 
* Navegadores de Internet especializados, suelen combinar voz y ampliación de imagen, facilitando la lectura de los textos, la búsqueda de enlaces (links) y otros elementos dentro de una misma página, envío y recepción de mensajes de correo electrónico, y la lectura de descripciones de gráficos. Un ejemplo es el WebSpeak de Productivity Works, que funciona de modo similar a otros navegadores, dando más uso al teclado antes que al mouse, pudiendo desactivarlo para evitar errores.

\section{3) Equipos autónomos de almacenamiento y proceso de la información}

\section{- Braille'n Speak (Imagen n04): tiene distintas} funciones de lectura y escritura, y permite comunicarse con otros sistemas a través de su unidad de disco. La entrada de datos se realiza mediante teclado Braille y la salida de información a través de voz sintética. Puede conectarse a un ordenador para intercambiar información con otros usuarios. Tiene un teclado, tipo máquina Perkins (6 teclas y barra de espacio). Su funcionamiento es similar al de un procesador de textos. Permite introducir información y almacenar archivos de texto para utilizarlos posteriormente. Está orientado especialmente como herramienta en la lecto-escritura, tratamiento de textos (almacena la información en archivos y carpetas), enseñanza/aprendizaje de la lengua escrita y herramienta que simplifica y facilita numerosas operaciones de escritura, transformación y proceso de reescritura.

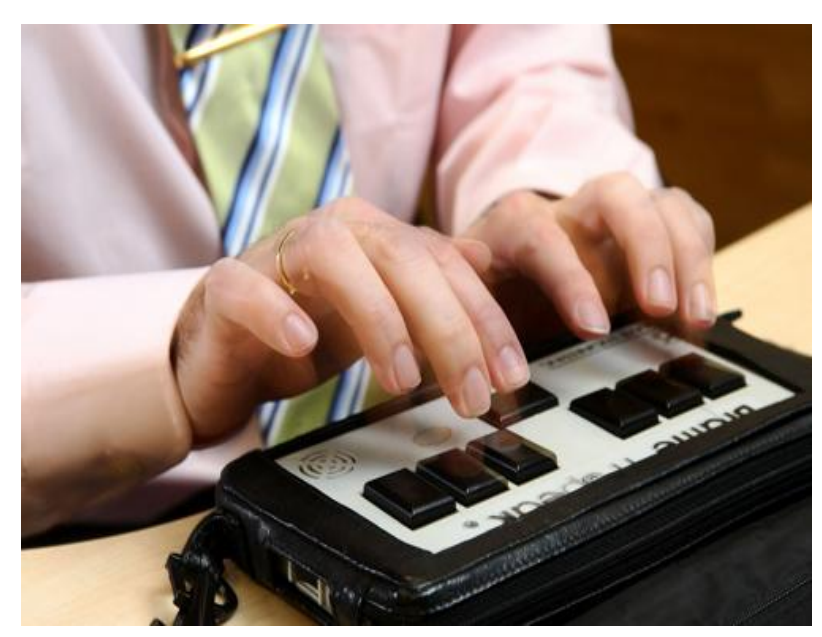

Imagen no 4 "Braille'n Speak" 
* Braille Lite: pequeña computadora portátil con código Braille. Dispone de una línea (de 18 ó 40 cajetines de Braille electrónico), lo cual permite a las personas con sordoceguera trabajar con el «Braille Hablado», ya que su forma de respuesta al usuario es la síntesis de voz y la línea de puntos. Almacena, procesa y edita textos y tiene reloj, cronómetro, calendario, alarma, agenda, calculadora, etc. La entrada de datos se realiza con teclado Braille y la salida es en este código o voz sintética.

* PAC Mate: anotador electrónico que incluye los últimos avances: conexiones USB, infrarrojos, sistema operativo Windows. Puede conectarse a un ordenador. Existen dos modelos, con teclado Qwerty y con teclado Braille.

* Sonobraille: anotador parlante que puede conectarse a un monitor, impresoras Braille o tinta, un ordenador o un teléfono (correo electrónico). Permite procesar información (escribir, borrar, corregir, buscar, imprimir), leer, redactar documentos, apuntes, tablas y datos, ejecutar programas en MS-DOS, intercambiar archivos con otros ordenadores, utilizar el correo electrónico y visualizar la información con un monitor de ordenador.

* Libros parlantes digitales: son conjuntos de piezas de información de distintos tipos, de naturaleza heterogénea y multimedia que constituyen una unidad lógica desde el punto de vista de la comunicación. Organizados según una estructura susceptible de consulta no-secuencial, por navegación y otros medios. Eventualmente susceptibles de manipulaciones diversas en función de la naturaleza de la información y el uso a que se destinen, están provistos del software aplicativo necesario para su consulta, manipulación, uso, y encapsulados en soportes electrónicos susceptibles de reproducción masiva o bien distribuidos en línea, cuyo objetivo es la distribución pública. Dentro de éstos, los libros parlantes combinan el texto propiamente dicho, al que se puede acceder mediante la ampliación de imagen, voz sintética y/o Braille), el sonido, los videos y gráficos.

- Reproductores de audio digital: muchas de las personas con dificultades en la visión implementan el uso de dispositivos 104 
más rápidos, livianos y fáciles de manejar como son los mp3, mp4 y mp5; algunas marcas poseen modelos muy sencillos en accesibilidad para las personas ciegas y disminuidas visuales, permitiendo conectarse en la computadora, e imprimir en la impresora Braille el material de forma autónoma e independiente.

Tabla No 9 "Enumeración recursos tiflológicos de alto nivel de especialización"

\begin{tabular}{|c|c|}
\hline $\begin{array}{c}\text { Adaptaciones tiflológicas de } \\
\text { alto nivel de especialización }\end{array}$ & Detalle de recursos \\
\hline Revisores de pantalla & Amplificadores o magnificadores de \\
caracteres
\end{tabular}




\subsubsection{Aspectos relevantes de los lectores de pantalla}

Los lectores de pantallas son aplicaciones software que identifican e interpretan lo que aparece por pantalla del ordenador con la finalidad de navegar por el sistema operativo. Pueden funcionar como Lectores de Textos y Magnificadores de Pantalla. Son útiles para personas con limitaciones visuales severas y ciegas ya que transmiten la información que no pueden ver.

La computadora se opera desde el teclado y el programa lector de pantalla verbaliza la información visible en el monitor. De este modo, una voz sintética se escucha por los parlantes de la PC, permitiendo al usuario acceder a las aplicaciones, tanto para la lectura como para la producción de un texto o documento, navegar por Internet, manejar su correo electrónico para comunicarse por mail y emplear los programas de conversación instantánea (Tiflolibros, 2011). ${ }^{35}$

Los usuarios pueden dejar que el programa lea automáticamente la totalidad de la información de la pantalla, yendo desde la parte superior de la misma hasta el pie, indicar una lectura línea a línea, o utilizar la tecla TAB para navegar entre enlaces de información.

Los archivos llamados 'scripts' o 'set files" configuran programas ya instalados en la computadora para una mayor compatibilidad con el lector de pantalla.

Es importante recordar que un lector de pantalla es un programa que tiene que ser instalado y configurado con un sintetizador de voz.

${ }^{35} \mathrm{http://www.tiflolibros.com.ar/contenido/Lectura.htm} \mathrm{consultado} 15$ diciembre 2011 106 
Hay varios programas de este tipo disponibles en el mercado, versiones profesionales, de bajo costo y de funcionamiento sencillo. Dependiendo la necesidad del usuario ciego, una versión puede ser más apropiada.

Los lectores de pantalla de nivel de sistema operativo mayormente utilizados se encuentran listados en la Tabla n010.

Tabla No 10 "Listado de lectores de pantalla disponibles en el mercado"

\begin{tabular}{|c|c|}
\hline $\begin{array}{l}\text { Nombre comercial } \\
\text { Lector de pantalla }\end{array}$ & Características \\
\hline BrowseAloud & $\begin{array}{l}\text { Destinado específicamente a leer el contenido de } \\
\text { las páginas web. Disponible para Windows y } \\
\text { para Mac. }\end{array}$ \\
\hline$\underline{\text { CLiCk, Speak }}$ & Desarrollado para el navegador Mozilla Firefox \\
\hline Dolphin Hal & Con soporte para línea Braille \\
\hline$\underline{\text { JAWS }}$ & $\begin{array}{l}\text { Uno de los mejores lectores de pantalla, } \\
\text { disponible en castellano entre varios idiomas. }\end{array}$ \\
\hline Dolphin SuperNova & $\begin{array}{l}\text { Con magnificador de pantalla y soporte para } \\
\text { línea Braille. }\end{array}$ \\
\hline Fire Vox & $\begin{array}{l}\text { Extensión del navegador Mozilla Firefox que } \\
\text { proporciona la capacidad de lector de pantalla. }\end{array}$ \\
\hline GW Micro Window-Eyes & $\begin{array}{l}\text { Compatible con los navegadores Microsoft } \\
\text { Internet Explorer y Mozilla Firefox. }\end{array}$ \\
\hline MexVox & $\begin{array}{l}\text { Desarrollado para Microsoft Windows gratuito, } \\
\text { implementación del sistema DosVox en } \\
\text { castellano. }\end{array}$ \\
\hline NVDA & Para Microsoft Windows gratuito. \\
\hline Orca & $\begin{array}{l}\text { Lector y magnificador para el sistema de } \\
\text { escritorio GNOME. }\end{array}$ \\
\hline System Access to Go & $\begin{array}{l}\text { Permite convertir en accesible cualquier } \\
\text { ordenador con conexión a Internet en pocos } \\
\text { segundos. }\end{array}$ \\
\hline$\underline{\text { Virgo }}$ & Lector y magnificador de pantalla. \\
\hline WebAnywhere & Lector de pantalla en la Web. \\
\hline ZoomText & $\begin{array}{l}\text { La versión Magnifier/Reader incluye un } \\
\text { magnificador de pantalla y un lector de pantalla. }\end{array}$ \\
\hline
\end{tabular}

Fuente: http://accesibilidadweb.dlsi.ua.es/?menu=lectores consultada enero 2012 


\subsubsection{El programa parlante JAWS}

(Acrónimo de Job Access With Speech)

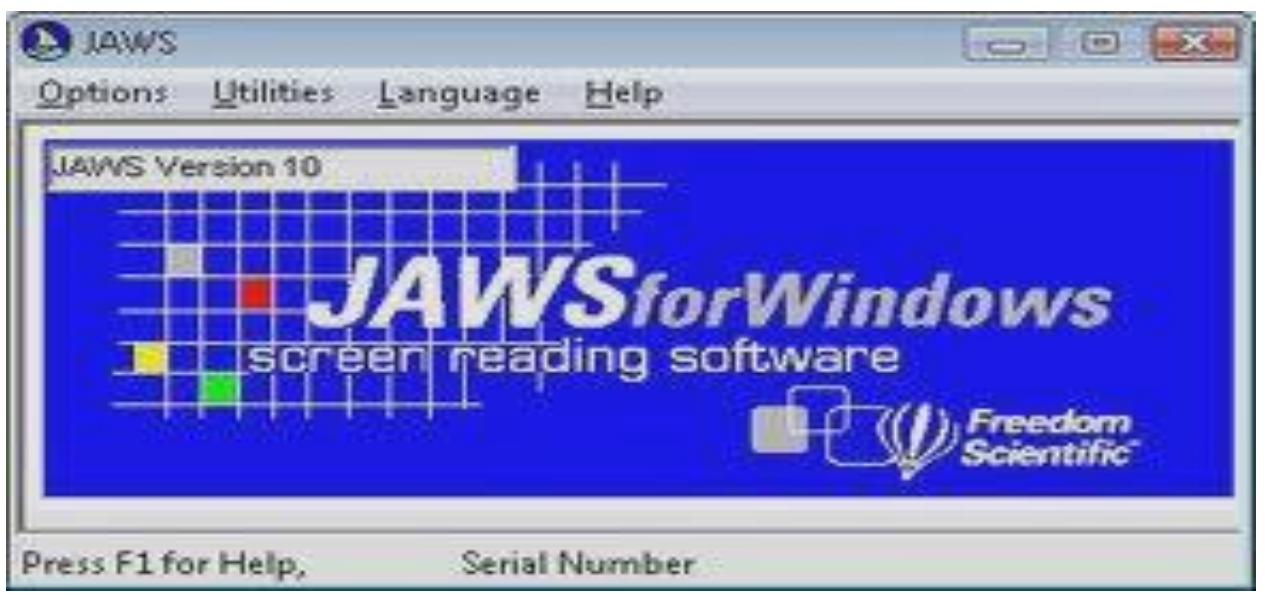

Imagen no 5 "Pantalla de inicio del programa JAWS"

Una de las ayudas técnicas utilizadas con mayor frecuencia y más conocida por las personas con dificultades visuales es Jaws para Windows (http://www.freedomscientific.com), un lector de pantalla que permite beneficiarse de la total gestión del ordenador y sus aplicaciones.

Tiene muchas posibilidades de configuración y es muy versátil, según las preferencias de cada usuario. Permite trabajar en la mayoría de las aplicaciones de Microsoft Office (Word, Excel, Access, Outlook, en Internet Explorer, aplicaciones de correo electrónico y herramientas de audio (reproductor de CD, grabadora de sonidos, etc.)

Las características técnicas de una de las últimas versiones son:

- JAWS Standard Español V. 11 Lector de Pantalla aplicable a Windows Vista Home Premium/Windows Vista Home Basic/Windows Xp Home

- JAWS Profesional Español V. 11 - Lector de Pantalla para Windows Vista $^{\mathrm{TM}} \quad$ Ultimate/Windows Vista Enterprise/Windows Vista Business/Windows Vista Home Premium/Windows Vista Home 
Basic/Windows 2000/Windows XP Pro/Windows XP Home/Windows Media Center /Windows 2003 Server

- $\quad$ Permite trabajar con MSN Messenger 7.0, 7.5 y 8.

- $\quad$ Permite trabajar con la versión 11 del Reproductor de Windows Media

- Soporta todas las aplicaciones de Windows estándar, sin la necesidad de hacer configuraciones especiales.

- $\quad$ Soporta Internet Explorer 7.x con características especiales: lista de links, listas de recuadros, lectura de tablas HTML, etiquetas de gráficos.

- Incluye una escritura de lenguaje único, para una mayor personalización con aplicaciones que no sean de Windows y software propios.

- Permite una salida a los visores más populares de Braille, en computadora o en Grado 2 de Braille.

Es una herramienta que facilita a la persona con discapacidad visual la ejecución de las actividades que se resuelven con una computadora; requiere concentración en el inicio del aprendizaje ya que su manejo es a través de combinaciones de teclas.

Para simplificar la tarea de los usuarios con limitaciones en la visión se emplea una estrategia de señalización de algunas teclas, las más importantes, favoreciendo el tipeo y evitando errores. A medida que la persona incorpora en su memoria kinestésica estas marcas específicas del teclado, ellas se retiran gradualmente (Mon, op.cit.).

La mayoría de los usuarios solicitan la adaptación de las siguientes teclas:

\section{enter-borrar-1-5-9-insert-shift}

Estas adecuaciones en el teclado benefician a las personas ciegas y con limitaciones visuales permitiéndoles mantener una correcta postura del torso frente a la computadora, evitando que se acerquen al teclado para visualizar las teclas en el caso de los usuarios con baja visión y generando menos tensión muscular (Mon, op.cit.). 
El programa Jaws tiene la capacidad de 'hablar' en siete diferentes idiomas, permitiendo optar el tipo de pronunciación, entonación y género de la voz sintética a escuchar. El usuario puede escoger entre español latinoamericano o español castellano, inglés americano, inglés británico, alemán, italiano, francés, portugués y finlandés. También pueden ajustarse las características de velocidad y volumen de lectura.

Para la instalación interactiva, el CD con formato Mp3 guía de modo sonoro el proceso de instalación; esto permite que una persona ciega pueda por sí mismo, incorporar el programa Jaws al ordenador. El programa cuenta con manuales impresos para la consulta de las personas que tienen resto visual y para los tutores con visión corriente.

Las personas ciegas que utilizan el sistema operativo DOS, pueden descargar la versión de Jaws para DOS desde la Red de modo gratuito. Cabe recordar que esta versión requiere un sintetizador de voz externo. 


\section{Diseño Metodológico}

\section{Capítulo V}

\section{Indagación del problema. Tiflotecnologías y accesibilidad}

El uso de medios tiflotecnológicos ha sido un gran avance para el progreso de las personas con limitaciones en la visión; el acceso al conocimiento a través de Internet se ha convertido en una herramienta de trabajo para los instructores de personas ciegas y con limitaciones visuales.

Además de navegar en la Web, estas personas acceden al correo electrónico, participan de listas de discusión y utilizan medios de comunicación en tiempo real como MSN (Messenger de Hotmail) y Skype. El uso de las TIC no se halla libre de obstáculos. Son numerosas las personas que ven restringida la oportunidad de adquirir y hacer uso de los conocimientos de esta manera, siendo parte de la brecha digital.

Para la participación efectiva en la información y la creación del conocimiento es necesario el acceso a la Web y el manejo de diferentes recursos informativos. Lograr la accesibilidad y usabilidad de estos recursos dentro de la nueva concepción de la información y el conocimiento, posibilita garantizar la igualdad de oportunidades para las personas con diversidad funcional; para alcanzar la participación activa de los ciudadanos en la sociedad del conocimiento.

Se realizó un trabajo de campo, indagando fortalezas y debilidades en uso de un lector de pantalla al acceder a entornos comunicacionales. Estos programas, como instrumentos de apoyo, permiten la interacción en el ciberespacio, que debe contemplar el menor número posible de obstáculos en el acceso. 
Considerando los ejes del marco teórico, si el entorno digital al que se pretende acceder se orienta al ámbito educativo, la identificación de dificultades relacionadas con la accesibilidad y usabilidad cobra valor adicional, por las consecuencias que implica.

La combinación del ordenador e Internet constituye una herramienta de gran valor para propender la autonomía personal en la vida diaria, en la educación y en el desempeño laboral de las personas con discapacidad visual (Mon, 2000).

La metodología de investigación empleada comprende un proceso de recolección y análisis de datos principalmente cualitativos. El diseño implica diferentes niveles de complejidad:

- Trabajo de campo. Encuestas y entrevistas en profundidad semiestructuradas, de modo presencial y vía correo electrónico.

- Investigación. Sistematización y análisis cualicuantitativo de datos para identificar los obstáculos más frecuentes en el acceso a entornos digitales.

- Contribución. Redacción de un manual complementario que orientará el desarrollo de espacios virtuales de enseñanza/aprendizaje para personas con limitaciones en la visión de diverso grado, que utilicen lectores de pantalla o magnificadores de imágenes para el acceso.

Este trabajo pretende destacar la importancia de la accesibilidad y usabilidad de los recursos digitales para lograr un uso eficaz y eficiente a la información por parte del colectivo de personas con limitaciones en la visión, así como sumar a la convocatoria a los desarrolladores de la Web para concretar mejoras del diseño y estructura que respondan a los criterios de $\mathrm{W} 3 \mathrm{C}$, en los que los entornos de enseñanza virtual forman parte. 


\subsection{Metodología de trabajo}

La primera etapa del trabajo consiste en la recopilación y el análisis de la bibliografía, informes y experiencias referidas a la temática de interés, de modo de identificar el estado de arte.

En una segunda instancia, se elabora un cuestionario de recolección de datos a ser aplicado con usuarios con limitaciones en la visión y con usuarios sin limitaciones pero relacionados con el uso del recurso digital de acceso a la Web. Es un trabajo de investigación no experimental, descriptiva.

\subsection{Caracterización de la muestra}

La población a consultar acerca de las dificultades y ventajas al utilizar los lectores y magnificadores de pantalla en el acceso a páginas Web tienen las siguientes características básicas.

- Edad: 13 años o mayores.

- Conocimiento en el uso de la computadora: nivel intermedio o más alto.

- Conocimiento en el uso de lectores/magnificadores de pantalla: nivel intermedio o más alto.

- Frecuencia de navegación en Internet: muy a menudo (2/3 veces por semana) como mínimo.

Se convocó a 35 usuarios con limitaciones en la visión en diverso grado (baja visión y ciegos), y 8 usuarios corrientes, con limitaciones mínimas o nulas, docentes o tutores de personas con dificultades visuales. La elección de la muestra obedece a que es una población que reúne como características comunes la dificultad en la percepción (en diferente grado) y su vinculación con entornos de enseñanza/aprendizaje, alumnos, docentes y personal a cargo de espacios dedicados específicamente a materiales 
tiflológicos. Contar con el aporte de este recorte de población, resulta valioso y significativo desde las líneas teóricas que orientan la consulta (Diseño universal, inclusión social, usabilidad y accesibilidad valorada por el usuario).

\subsection{Caracterización de los instrumentos}

Los instrumentos de recolección de datos son cuestionarios de entrevistas semiestructuradas y encuestas, autoadministradas y presenciales. Dicha selección intenta conseguir un cruce de datos de modo de lograr la identificación lo más objetiva posible, de elementos facilitadores/obstaculizadores en el uso de los lectores y magnificadores de pantalla, sin quitar mérito a las valoraciones de los usuarios desde sus percepciones subjetivas, personales, referidas al uso de los recursos.

Los protocolos ${ }^{36}$ empleados en las encuestas constan de siete preguntas cerradas, con elección de opciones y seis preguntas abiertas.

La entrevista semiestructurada está compuesta por trece preguntas a responder recogiendo opiniones, ejemplos y sugerencias de los usuarios, con posibilidad de repreguntas.

Tanto la encuesta como la entrevista permiten agrupar las preguntas en seis aspectos:

- Datos personales del encuestado/entrevistado.

- Uso de Internet (frecuencia, objetivo de uso, tipo de navegador)

- Empleo de lectores de pantalla o magnificadores de imágenes (frecuencia, tipo de software)

- Ejemplos de páginas visitadas (motivo de la elección, intencionalidad de la consulta, acciones que realiza)

${ }^{36}$ Consultar anexo 1. 
- Facilidades o ventajas en el acceso y navegación de los ejemplos escogidos.

- Dificultades o desventajas en el acceso y navegación de los ejemplos escogidos.

\subsection{Relevamiento de datos}

Luego de la recolección de datos podemos observar que:

Gráfico N04

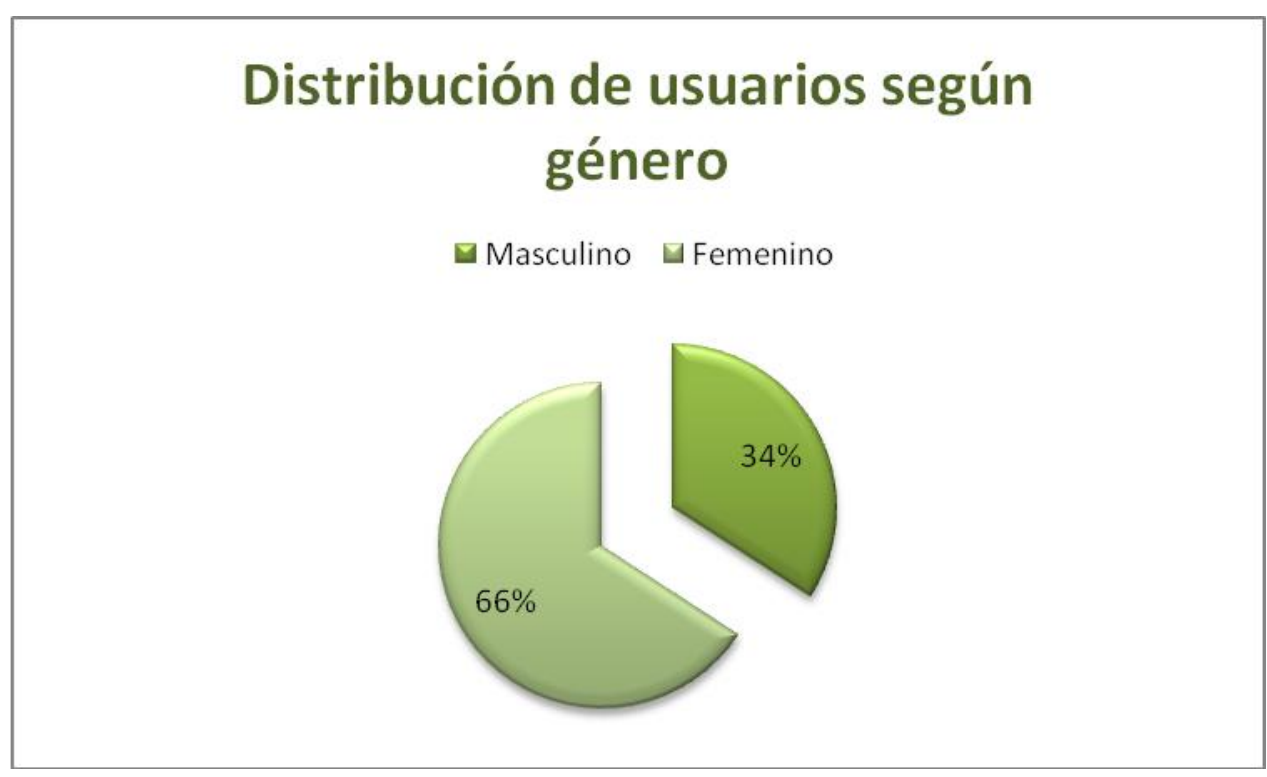

$\mathrm{N}=43$ usuarios

La distribución por franjas etarias y niveles de educación formal logrados da cuenta que los estudios superiores, completos o en curso, corresponden principalmente a las edades del cupo 2 (19 a 29 años). 


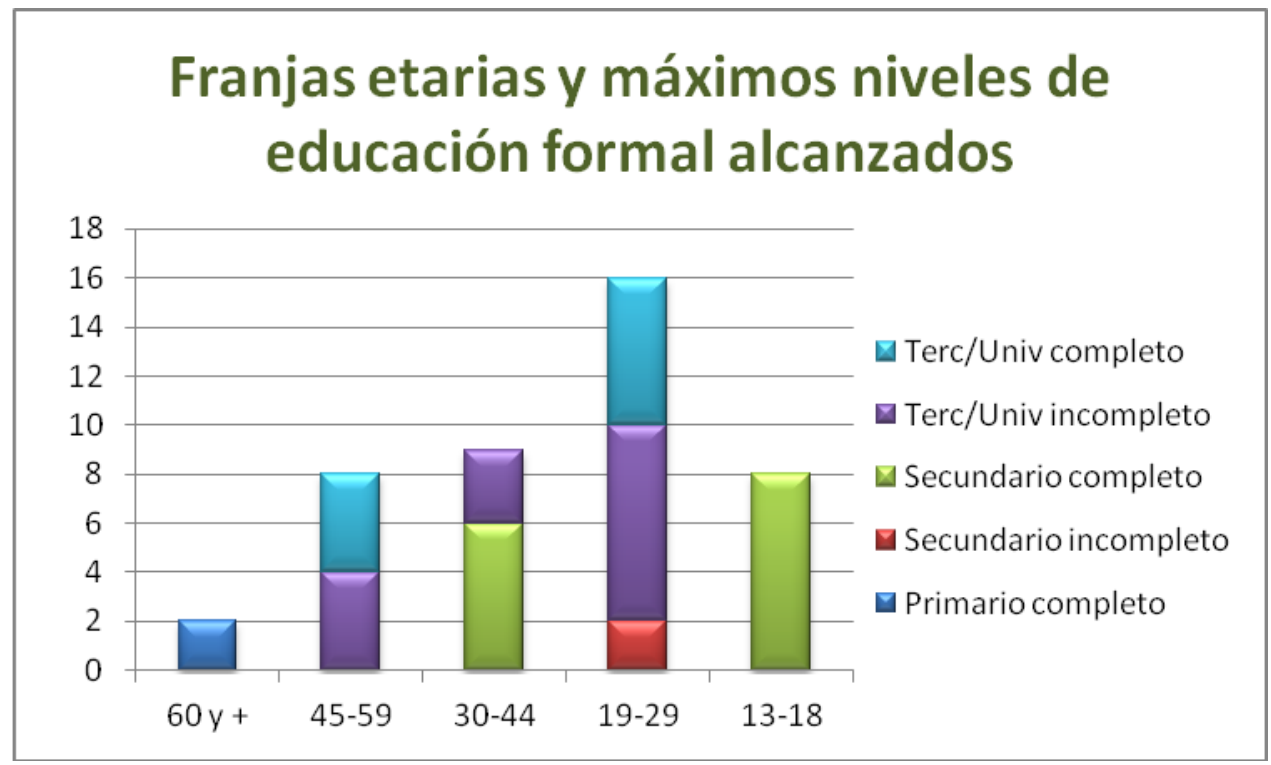

$\mathrm{N}=43$

Puede observarse que la navegación por la Web realizada diariamente es la que muestra el mayor cupo de usuarios.

Gráfico No6

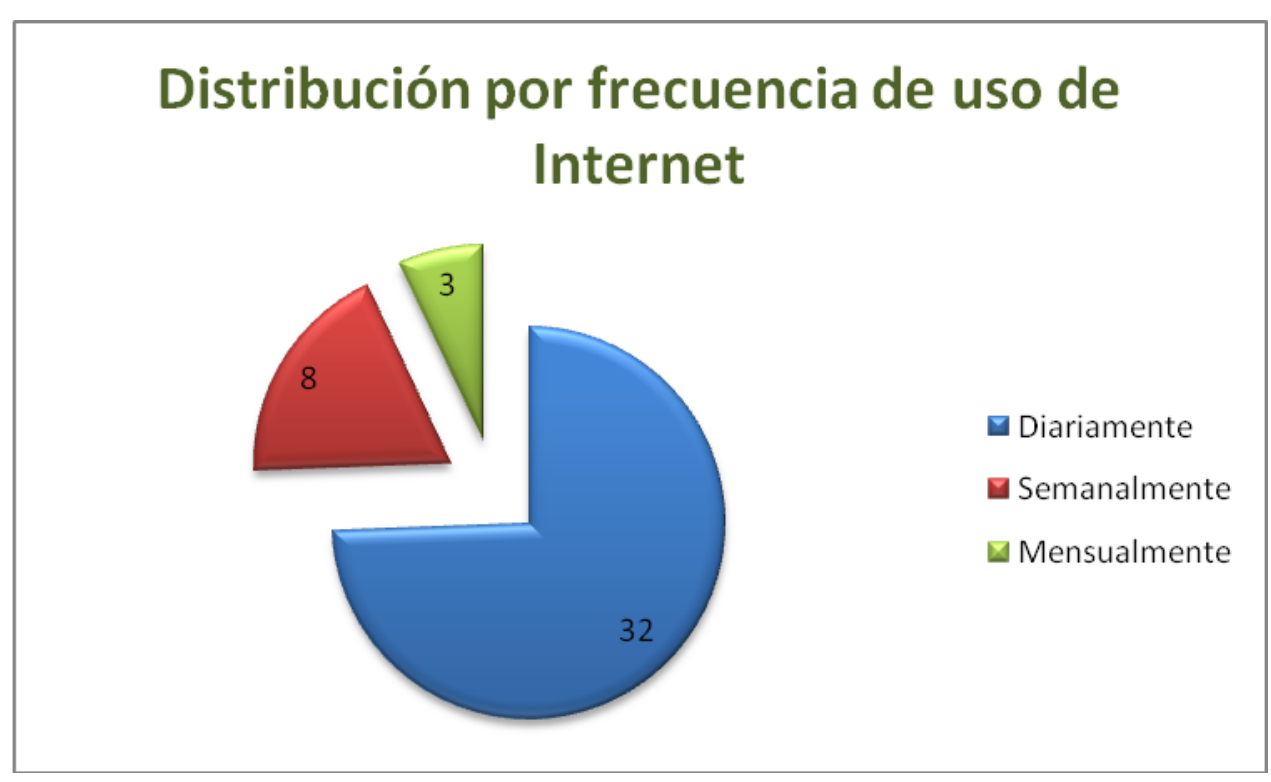

$\mathrm{N}=43$ 
Las tareas desarrolladas con mayor frecuencia, están referidas a entablar comunicaciones en distintos entornos sociales virtuales, mostrando un porcentaje similar, tanto el uso para el ocio y recreación, como para aplicaciones académicas. Todas tareas que ponen en juego las características de la interconectividad, interactividad y comunalidad de las TIC.

Gráfico No 7

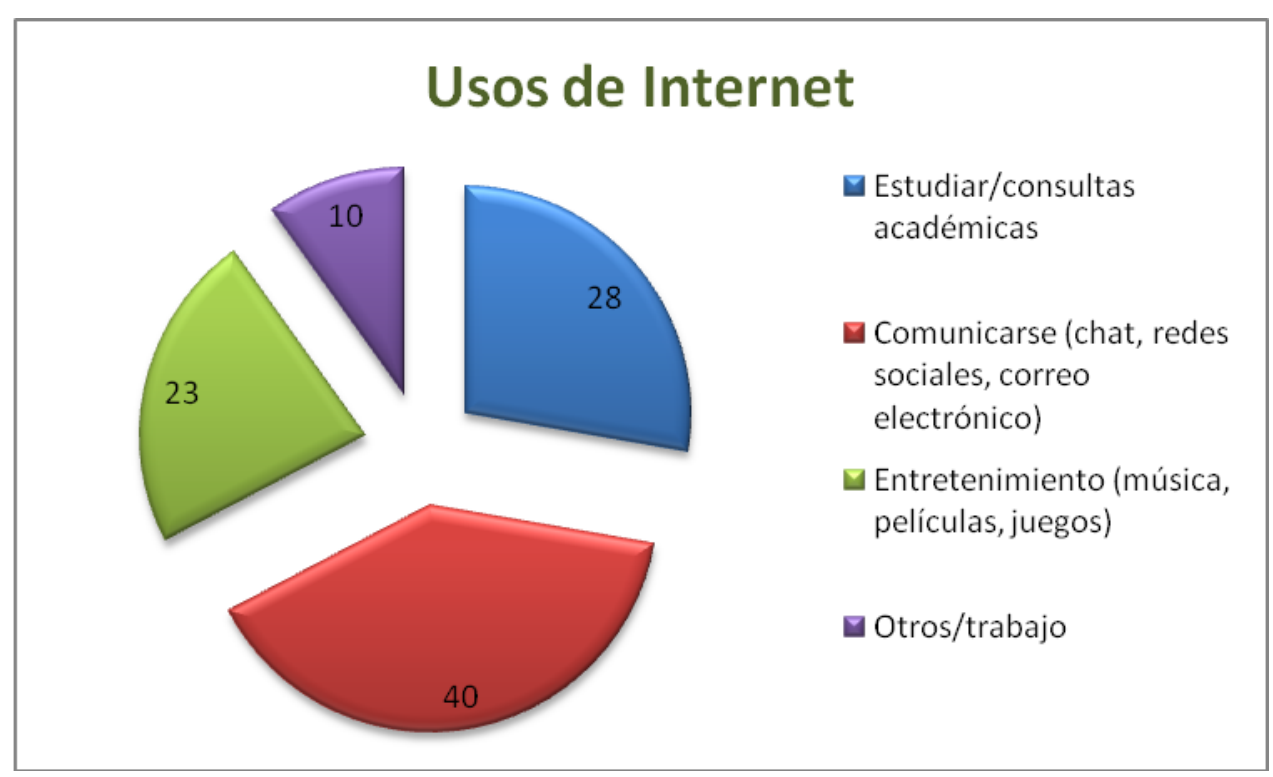

$\mathrm{N}=43$ 
El navegador de Internet más utilizado es el Internet Explorer. Cabe aclarar, que varios usuarios indicaron el empleo de más de un navegador, dependiendo del tipo de pantalla a la que se pretende acceder.

\section{Gráfico No8}

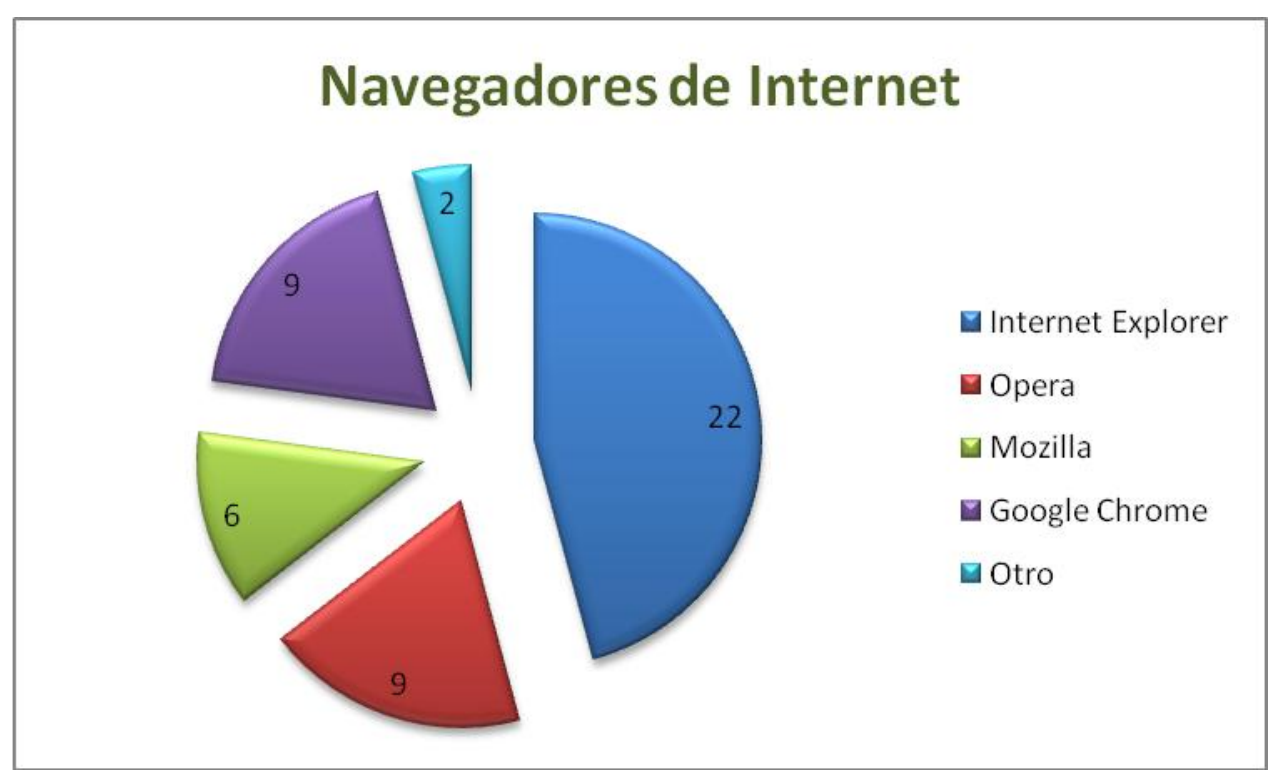

$\mathrm{N}=43$

En relación a la frecuencia de uso, varios internautas indican que utilizan el lector de pantalla aún teniendo resto visual pues simplifica el acceso a la información. Aquellos usuarios relacionados con el uso de lectores de pantalla, pero con un grado de visión corriente, emplean esas herramientas para evaluar los sitios Web previamente a ser indicados como espacios de estudio o trabajo para sus alumnos con limitaciones en la visión. 


\section{Frecuencia en utilización de lector de pantalla}

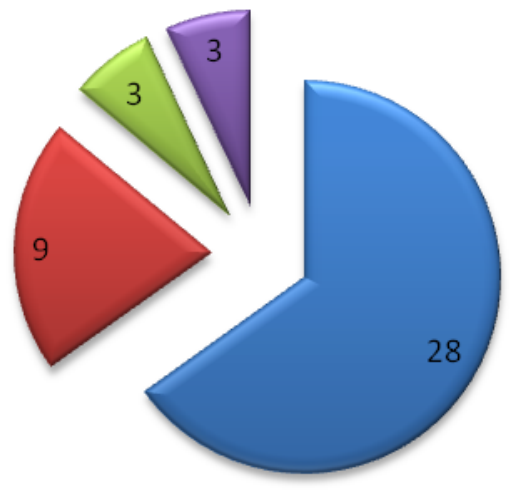

口iempre

$\square$ a veces por dificultad en la visión

$\square$ a veces sin dificultad en la visión

$\square$ ocasionalmente

$\mathrm{N}=43$

Gráfico No 10

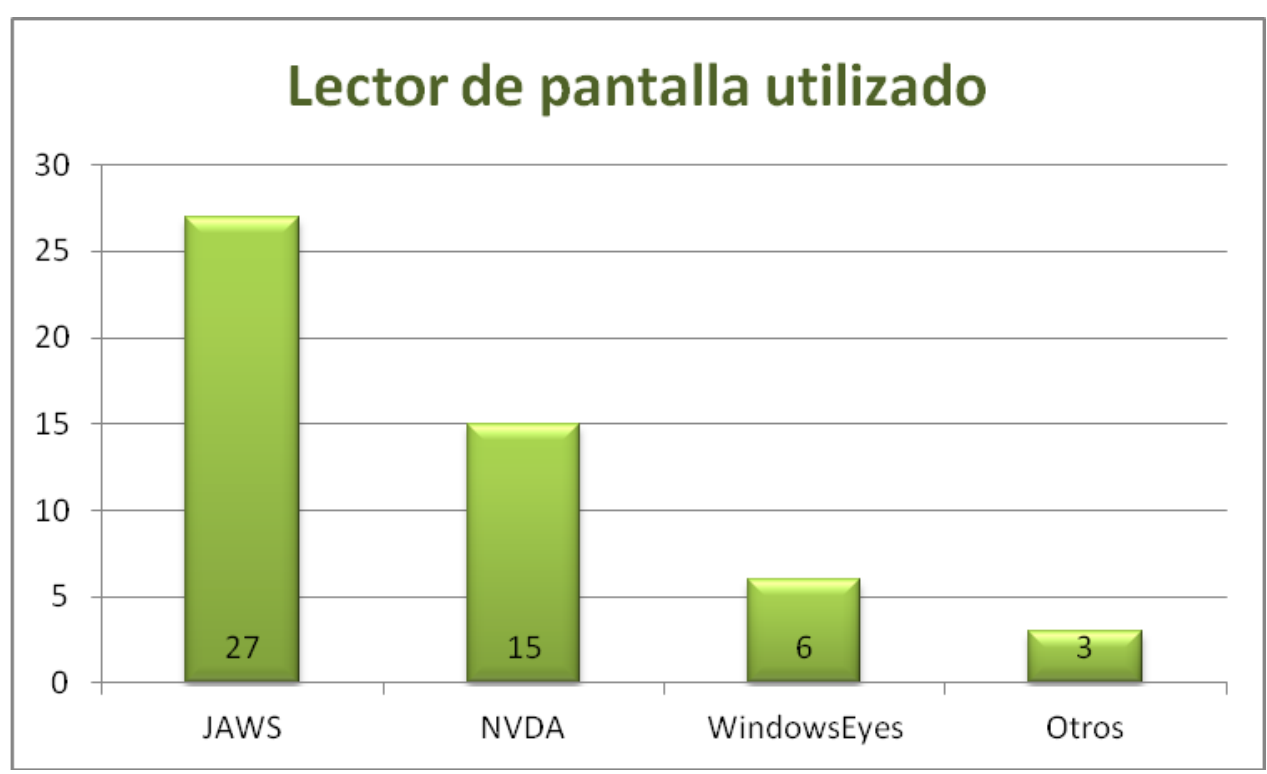

$\mathrm{N}=43$

Cabe aclarar que varios usuarios emplean dos lectores de pantalla, mostrando preferencia por el programa JAWS.

En lector identificado con la opción "otros" corresponde al programa ORCA. 
Gráfico No 11

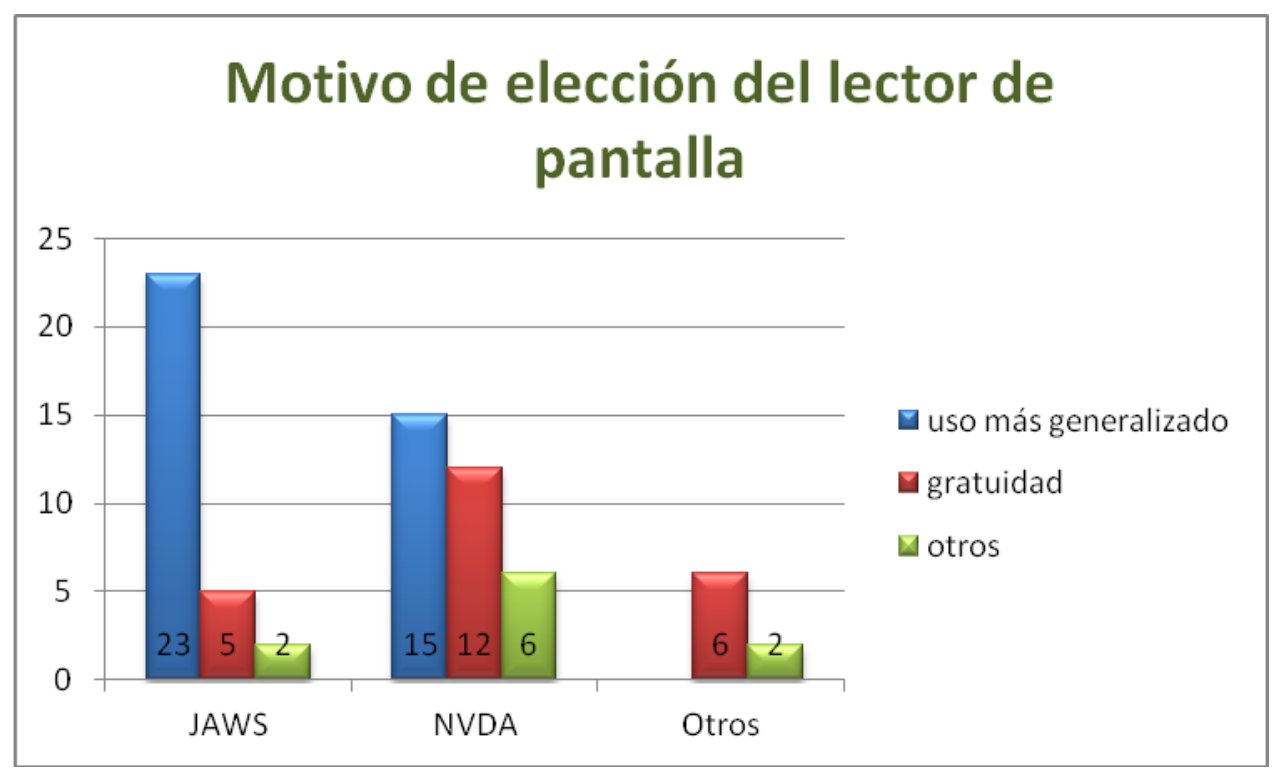

$\mathrm{N}=43$

En el gráfico No 11 puede observarse que la elección del programa JAWS obedece a su generalización de uso en el mercado. Si bien no es gratuito, varios usuarios prefieren emplear las versiones de prueba, disponibles por 40 días, ejecutando nuevamente esta versión al caducar el permiso de uso sin costo.

En la columna identificada con la leyenda "otros", quedan agrupadas razones coyunturales, como: ser el único lector de pantalla instalado en el lugar de trabajo o de estudio; haber recibido el programa en legado por parte de otro usuario.

Las páginas o sitios más consultados son aquellos que permiten interacción con otros usuarios, mediante redes sociales y el buscador de Google. 
Gráfico No 12

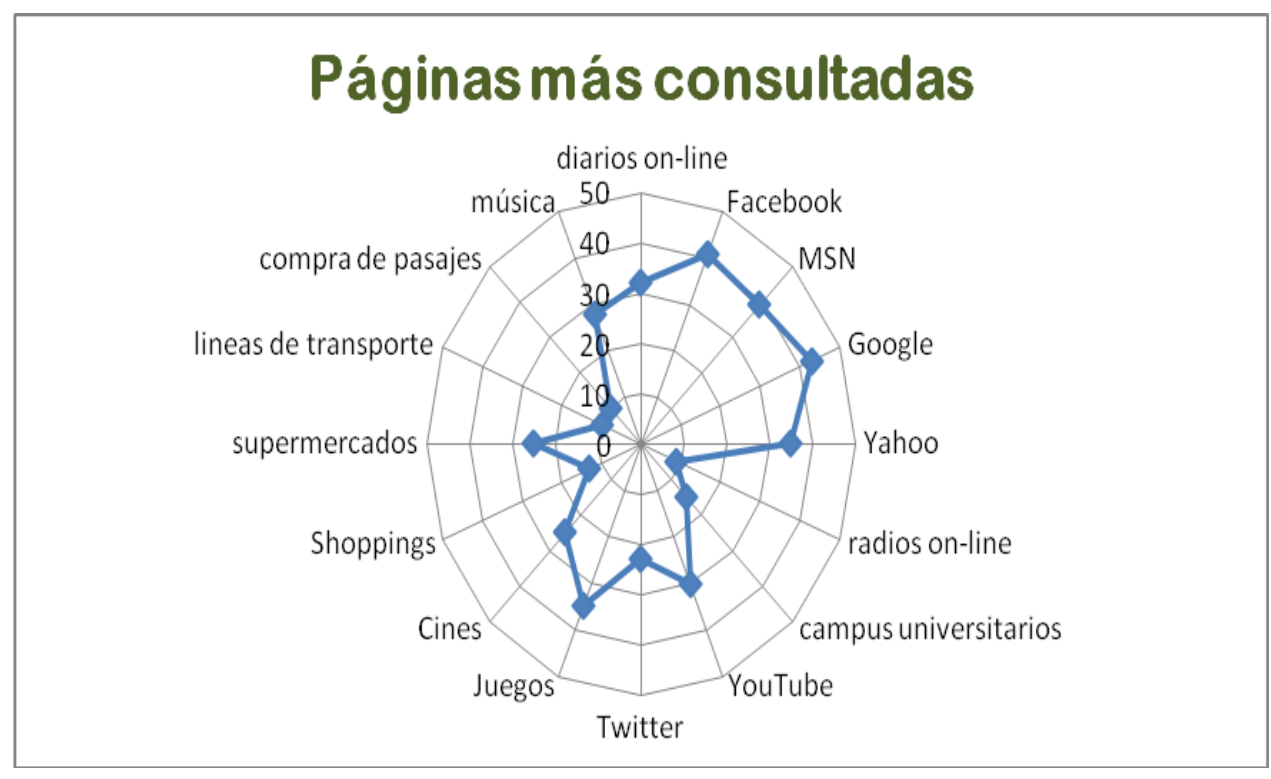

$\mathrm{N}=43$

Al consultar el por qué de la elección de las páginas anteriores, pueden agruparse las respuestas en los ítems expuestos en el gráfico nº 13.

Gráfico No 13

\section{Motivo de elección de páginas consultadas}

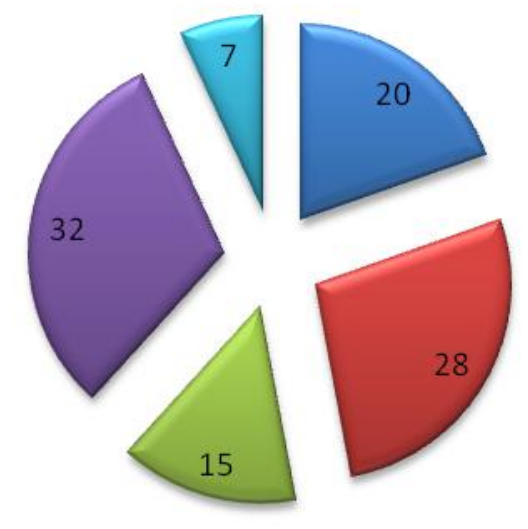

- Obligación

Interés personal

$\square$ Necesidad

\Preferencias de accesibilidad

$\square$ Otros

$\mathrm{N}=43$ 


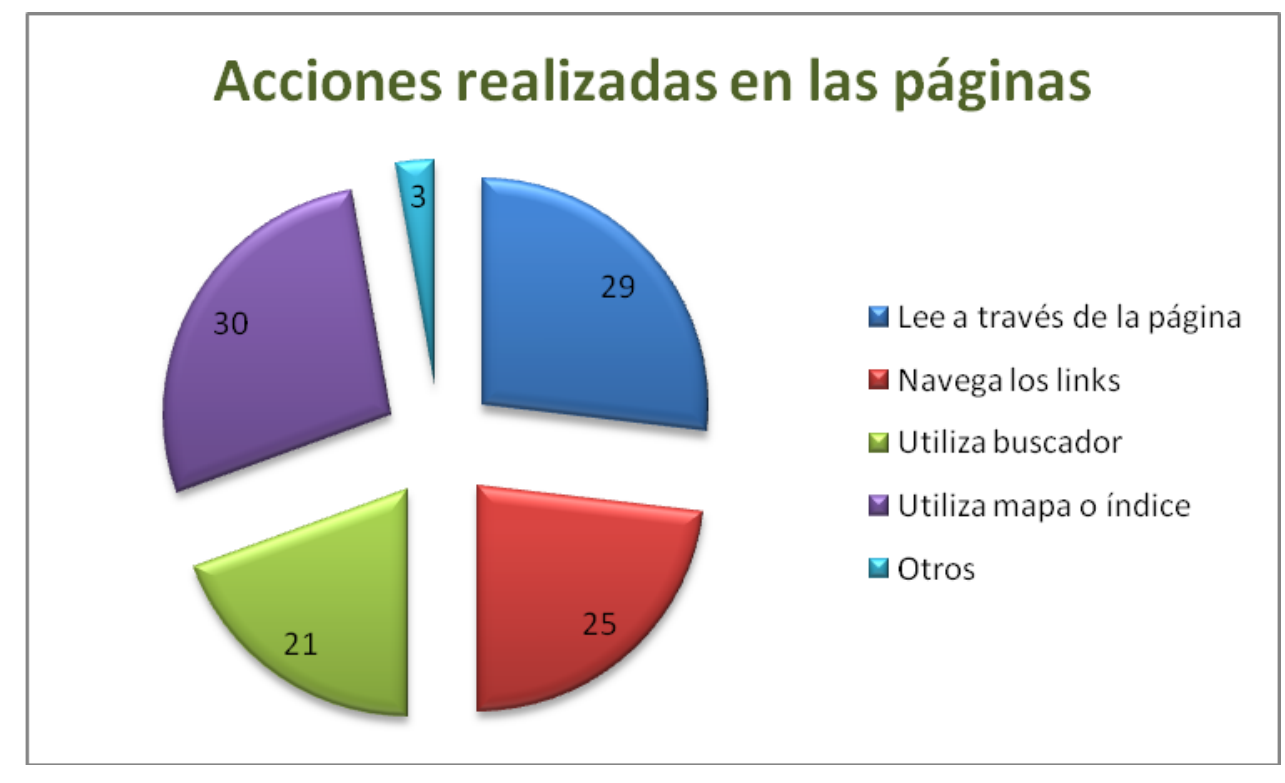

$N=43$

Una de las acciones más realizadas es aproximarse al total de la información que se publica en una página mediante la lectura del mapa del sitio o de los índices disponibles. De ese modo, se logra un primer criterio de selección del contenido del sitio, agilizando la lectura.

En relación a la información recogida en la preg. No 11 de la encuesta y la preg. No 9 de la entrevista, se identifican las características de los sitios Web, al momento de emplear el recurso digital de acceso a las pantallas graficadas en la Tabla no 11. 
Tabla No 11 "Cuadro resumen de datos referidos a ventajas o facilidades al acceder mediante lectores/magnificadores de pantalla"

\begin{tabular}{|l|}
\hline $\begin{array}{c}\text { Ventajas/Facilidades al acceder a los sitios mediante } \\
\text { lectores/magnificadores de pantalla }\end{array}$ \\
\hline Secciones bien delimitadas y en número justo. \\
\hline Información bien organizada, lenguaje claro y preciso. \\
\hline Descripción detallada de imágenes. \\
\hline Presencia de un buscador interno incorporado. \\
\hline Coincidencia entre el lenguaje de programación y lo que se muestra en la interfaz. \\
\hline Links para la navegación bien especificados, con botones con significado. \\
\hline Formularios fáciles de completar o comprender. \\
\hline Encabezados en las pantallas en número limitado y bien identificados \\
\hline Número limitado de ventanas emergentes (pop-ups) \\
\hline
\end{tabular}

Con respecto a los datos recogidos en la preg. No 12 y 10 de la encuesta y entrevista respectivamente, se enumeran las siguientes características problemáticas de los sitios Web, al momento de emplear los recursos de acceso. (Tabla no 12) 
Tabla N012 "Cuadro resumen de datos referidos a desventajas o dificultades al acceder mediante

lectores/magnificadores de pantalla"

\begin{tabular}{|l|}
\hline \multicolumn{1}{|c|}{ Desventajas/Dificultades al acceder al sitio mediante } \\
lectores/magnificadores de pantalla \\
\hline Información agrupada de modo confuso. \\
\hline Encabezados que no reflejan el contenido. \\
\hline Lenguaje poco corriente; empleo de siglas o abreviaturas. \\
\hline Imágenes con descripción textual con poca información o sin texto alternativo. \\
\hline Falta de buscador interno. \\
\hline Buscador interno ubicado en un espacio de la pantalla no convencional (fuera del \\
ángulo superior derecho). \\
\hline ítems. \\
\hline Utilización de programas que dificultan el uso de lectores de pantalla. Ej. Flash \\
\hline Número excesivo de ventanas emergentes (pop-ups). \\
\hline Enlaces en exceso, sin posibilidad de "saltar al contenido principal" \\
\hline Utilización de CAPTCHA sólo en imágenes. \\
\hline
\end{tabular}


Recapitulando, podemos observar que el grupo de usuarios consultados indica una frecuencia diaria del $74 \%$ en actividades relacionadas con el uso de la Red (Gráfico no 6) accediendo preferencialmente con el lector de pantalla JAWS o NVDA (Gráfico no 10) en forma combinada con el uso del navegador Microsoft Internet Explorer (Gráfico nº 8).

Los espacios con los que interactúan son los referidos en primer término a la comunicación (sincrónica y asincrónica) con otros, con un 93\% de elección (chat, redes sociales, correo electrónico), continuando las actividades de formación y consulta académica con un $65 \%$ y los sitios de entretenimiento con un 54\%. (Gráfico no 7).

Las páginas más visitadas muestran coincidencia con las actividades de mayor frecuencia realizadas en la Red, como Facebook, MSN, o Yahoo. (Gráfico no 12). Llama la atención una alta preferencia de sitios observados con poca accesibilidad por parte de evaluaciones tales como las realizadas por Discapnet y Fundación $\mathrm{ONCE}^{37}$, que ubican a las plataformas de redes sociales en un nivel de accesibilidad bajo.

Considerando los motivos de consulta de las páginas Web (Gráfico no 13), y contemplando las evaluaciones acerca de las facilidades de acceso, puede aventurarse la suposición de que las preferencias de este grupo de usuarios no necesariamente coinciden con altos niveles de accesibilidad en las mismas.

Los datos observados en el gráfico no 14 muestran las acciones más frecuentes al leer una página digital mediante lectores de texto. De esto se desprende que son elementos de importancia al desarrollar un sitio Web: la ubicación de un mapa o índice que adelante al internauta el contenido; enlaces identificados correctamente, con una etiqueta relacionada con el tema o concepto a consultar en la página a la que redirecciona, y una organización de "encabezados" con etiquetas de igual características.

\footnotetext{
${ }^{37}$ Para ampliar datos consultar

http://www.discapnet.es/Castellano/areastematicas/Accesibilidad/Observatorio infoaccesibili dad/informesInfoaccesibilidad/Paginas/AccesibilidaddePlataformasdeRedesSociales.aspx" 


\section{Capítulo VI}

\section{A modo de conclusión}

A lo largo de estas páginas intentó ponerse de manifiesto el potencial que tienen las TIC para facilitar la inclusión de las personas con diversidad funcional.

La presencia de estas tecnologías en los distintos ámbitos es indiscutible, y en aumento. El grupo de usuarios consultados, dan cuenta del amplio abanico de actividades en que son empleadas, con una frecuencia de uso significativa.

Las TIC permiten positivos cambios en las formas de comunicarse, relacionarse, ampliar capacidades y participar en la sociedad a la que pertenecen los sujetos. Es decisivo que los espacios de intercambio sean accesibles para que la información a comunicar llegue a su destinatario de modo completo y apropiado, permitiendo la construcción de conocimiento.

Ante las particularidades de los usuarios, quedó expuesto en el presente trabajo de tesis que el acceso para todos, el diseño accesible, llamado Diseño Universal, es una noción clave en el empleo de las TIC y el respeto a la diversidad. Permite reducir la llamada brecha digital y facilita la participación en la SIC, incluso de los grupos sociales vulnerables.

El actuar humano se potencia cuando la discrepancia sujeto-entorno se reduce y los resultados personales en la resolución de tareas, mejoran.

En relación al derecho a la educación, las herramientas digitales resultan elementos colaboradores del aprendizaje, el desarrollo y la mejora de la cognición.

Con respecto a los aspectos psicopedagógicos de los entornos educativos apoyados por las TIC, parece existir consenso de que éstos debiesen permitir relaciones de interacción variada, una educación altamente individualizada y centrada en el aprendiz, enfocada en promover la 
adquisición de competencias de alto nivel, así como pensamiento complejo y aprendizaje colaborativo (Díaz Barriga, 2005, 2007).

Si consideramos que las computadoras y en general las TIC sirven como herramientas para la construcción del conocimiento, y para que los usuarios/alumnos aprendan con ellas, las tecnologías deben permitir interpretar y organizar el conocimiento personal, apoyar la representación en diversos modos de aquello que se conoce o se desea aprender, involucrar el pensamiento crítico acerca del contenido que se está estudiando y permitir la comunicación y colaboración entre los usuarios (docentes y/o alumnos) comprometidos en el aprendizaje.

El instrumento cultural que se emplea para comunicar e interactuar con las personas afecta el "cómo y el qué" del pensamiento. La capacidad de simbolizar un concepto dentro de los límites y posibilidades de una forma de representación, pone al usuario a actuar cognitivamente en el marco del sistema representacional seleccionado.

La posibilidad de representar simbólicamente la realidad externa al sujeto mediante modelos mentales, hace posible la consecución de la experiencia. Estas construcciones no son estáticas, se modifican en el transcurso de los años de actividad cognitiva del sujeto, haciendo posibles nuevas interpretaciones de la realidad en función de las experiencias atesoradas.

La realidad que se construye es abierta, incompleta y ampliable (Norman, op.cit.) Permite relacionar los conocimientos en forma de redes interconectadas de representaciones de objetos, sucesos y conceptos, formando la base estructural que otorga significado al mundo externo al sujeto.

El contar con múltiples formas de representación para trabajar, transmitir y compartir significados facilita y favorece la comunicación entre las personas y en consecuencia, el desarrollo cognitivo.

La construcción de ambientes ricos en recursos resulta más afín a las condiciones cotidianas en que las personas resuelven los problemas, en contextos significativos, facilitando la posterior transferencia. 
Los entornos digitales modifican el modo de producir y distribuir el conocimiento, y en consecuencia las relaciones de enseñanza/aprendizaje.

Considerar la educación como un derecho de todos, implica explícitamente contar con todos los miembros de la sociedad, con diversas características, formas de socializarse, moverse o aprender. Las TIC pueden contribuir a hacer efectivo este derecho a participar de los entornos de formación, virtuales o presenciales, dando respuesta concreta al trabajo con la diversidad. Es valioso destacar que para muchas personas resultan la única forma de acceso a los entornos educativos, para participar de forma plena y efectiva.

El uso de las TIC para la conformación de comunidades de aprendizaje facilita la puesta en práctica de características como responsabilidad, autonomía, habilidades comunicacionales, sociales, intencionalidad. Permiten actividades colaborativas entre los sujetos que aprenden y con los artefactos y sistemas simbólicos involucrados en el acto de conocer.

Los aprendizajes logrados en entornos digitales colaborativos, dan lugar a resolución de problemas mediante la puesta en práctica de capacidades propias del sujeto, en colaboración con las de las herramientas digitales. Es un sistema conformado por la suma de capacidades.

A partir de los datos recogidos mediante la consulta a usuarios, puede observarse que tanto la frecuencia de uso como las actividades realizadas corresponden a prácticas virtuales cotidianas de interacción con otros.

Analizar y considerar los modos de intercambio ya aprendidos y adoptados por los sujetos, para ser empleados en entornos digitales orientados a la educación, implica facilitar la cognición de los mismos. Pueden aplicarse habilidades cognitivas automatizadas, como los modos de navegación, detectar patrones similares, distribución de la información, modos de operar en la búsqueda y selección de datos; se libera capacidad cognitiva para abordar elementos novedosos para el internauta, como las características particulares del contenido a trabajar, resolución de problemas relacionados con éste, identificación de relaciones conceptuales. 
Las negociaciones de significados y los modos representacionales conocidos previamente por las personas colaboran con la accesibilidad y usabilidad de los entornos digitales, atributos del diseño. Los patrones conocidos por los usuarios minimizan la carga cognitiva necesaria para la interacción y la toma de decisiones.

Contemplando los motivos por los cuales los usuarios consultados acceden a determinadas páginas digitales, encontramos un porcentaje similar entre los sitios visitados porque "se precisa su consulta" y aquellos que son "preferidos por su nivel de accesibilidad". Podría presumirse una modificación en los porcentuales, si aquellas páginas visitadas por necesidad u obligación se tornan más accesibles, mediante la observación de los principios de diseño universal ya nombrados.

Los entornos digitales y particularmente los referidos a aspectos o actividades educativas deben observar los principios de accesibilidad, usabilidad e interoperabilidad, a los efectos de facilitar la participación del mayor número de usuarios posibles.

Mediante la sistematización de las respuestas referidas a las ventajas o facilidades observadas en las páginas preferidas por los usuarios interrogados, pueden listarse los elementos que favorecen el acceso a la información y contemplarse aquellos que lo obstaculizan.

Suscribiendo a la concepción de que las barreras de acceso limitan las capacidades de los sujetos, se aspira a aportar en la mejora de la accesibilidad y usabilidad de las TIC. 


\section{Contribución}

Una gran cantidad de tutoriales y artículos introductorios de accesibilidad han sido escritos por los desarrolladores Web; nuestro estudio pretende plasmar en un documento de comprensión sencilla, redactado en un lenguaje claro para aquellos que no necesariamente operan con conocimientos de programación, elementos acerca de cómo mejorar el diseño de los entornos de enseñanza/aprendizaje de modo de ser amigables, en términos de posibilidades de interacción y acceso, para los usuarios/alumnos, particularmente para el grupo de personas con limitaciones en la visión. (Ver anexo II)

Es un documento cuyo objetivo es facilitar el trabajo de los grupos docentes implicados en el diseño de entornos virtuales, acompañando a los estudiantes en el logro de aprendizajes significativos, donde el acceso al entorno y la presentación de los contenidos inviten a la participación.

Un espacio colaborativo accesible y usable permite la conformación de una comunidad cooperativa, que puede sostenerse a lo largo de un tiempo acordado, con el objetivo de producción conjunta de información y conocimiento, pudiendo lograr una gestión autónoma.

El Manual complementario, considera la mirada de Donath (2003) que sostiene que los arquitectos/desarrolladores/creadores del espacio virtual, desde los diseñadores de software hasta los administradores de los entornos Web, dan forma a la comunidad más profundamente de lo que hacen sus colegas en el mundo real o físico. Los edificios de ladrillos no controlan la percepción de sus habitantes. En el ámbito electrónico digital, el diseño del entorno es un elemento destacado. Puede tanto incluir como excluir a los usuarios.

Pretende ser una guía que acompañe la lectura de las directrices de accesibilidad Web desarrolladas por los organismos internacionales dedicados a la investigación, desarrollo y divulgación del tema, el W3C y WAI. Busca ser un texto de consulta rápida y sencilla de aspectos básicos 
relativos a la accesibilidad de sitios Web, particularmente orientado a trabajar los obstáculos que se presentan a las personas con limitaciones en la visión y ciegos.

\section{$\underline{\text { Trabajo a futuro }}$}

Se proponen futuras líneas de trabajo en relación al recurso desarrollado, con el fin de evaluar:

- Claridad en la comunicación de los conceptos de accesibilidad, usabilidad, diseño universal.

- Uso de un lenguaje corriente, comprensible, de fácil interpretación para aquellos lectores interesados en el diseño de entornos digitales accesibles sin conocimientos específicos en lenguajes de programación.

- Valor de referencia de los ejemplos seleccionados.

- Viabilidad de las sugerencias y recomendaciones del manual al momento de diseñar un entorno digital educativo.

- Grado de mejoras en la accesibilidad de espacios virtuales modificados al considerar las recomendaciones o sugerencias del documento redactado.

- Relación entre el entorno de comunicación e información diseñado y los procesos de aprendizaje que ocurran en éste.

Si bien puede realizarse una evaluación mediante las herramientas de validación descriptas en el capítulo III, la propuesta es recuperar, mediante la experiencia directa, la valoración de los usuarios al trabajar con el documento redactado y del entorno virtual diseñado resultante. 
Las acciones a realizar están orientadas a un trabajo colaborativo con los espacios de investigación, formación y divulgación de temas relativos a materiales tiflológicos y personas con limitaciones en la visión, contactados para la elaboración del presente trabajo de tesis: Biblioteca Argentina para Ciegos, Tiflonexos y Grupo CRE.

Es la intención ampliar los espacios de intercambios académicos y de experiencias, a partir de la difusión de la propuesta con miras a enriquecerla. 


\section{Bibliografía consultada}

- ALADI/SEC/Estudio 157. Rev. 1. 30 de julio de 2003. La brecha digital y sus repercusiones en los países miembros de la ALADI Asociación Latinoamericana de Integración

- Alcantud, Francisco; Soto, Javier (Coords.) (2003) "Tecnologías de ayuda para personas con trastornos de la comunicación". Valencia. Ed. Nau Llibres.

- Alonso, C y Santarosa, L (2006) "Letramento e inclusão digital de pessoas com necessidades educacionais especiais". CIIEE 2005.

- Area Moreira, M (2009) "Introducción a la Tecnología Educativa", España, Universidad de La Laguna.

- Ausubel, D. (2002) "Adquisición y retención del conocimiento" Barcelona, Paidós.

- Azinián, H (2008) "Las tecnologías de la información y la comunicación en las prácticas pedagógicas" Herminia Azinián. Editorial Noveduc Libros

- Batista, María Alejandra (2007) "Tecnologías de la información y la comunicación en la escuela : trazos, claves y oportunidades para su integración pedagógica", Buenos Aires : Ministerio de Educación, Ciencia y Tecnología de la Nación

- Berners-Lee, Tim (2004) "Speech and the Future" http://www.w3.org/2004/Talks/0914-tbl-speech/text

- Berners-Lee, Tim (2009) "The Great Unveiling" conference TED, Long Beach, CA. USA

- Bransford y Vye. (1996) "Una perspectiva sobre la investigación cognitiva y sus implicaciones para la enseñanza". En Curriculum y cognición. Resnick y Klopfner. Buenos Aires, Aique.

- Bruininks, R. H., Meyers, C.E., Sigford y Lakin, K. C. (1981) "Deinstitutionalization and community adjustment of mentally retarded people". Washington, D.C, American Association on Mental Deficiency.

- Bruner, J (1988) "Desarrollo cognitivo y educación". Madrid, Ediciones Morata.

- Bruner, J (1997) "La educación puerta de la cultura". Madrid, Ed. Visor.

- Bruner, J. (1966) "Toward a Theory of Instruction". EE.UU President and Fellows of Harvard College.

- Bruner, J. (2001) "El proceso mental en el aprendizaje". Madrid, Ed. Narcea. 
- Burbules, N. C. y Callister, T.A. (2001) "Educación: riesgos y promesas de las nuevas tecnologías de la información". España:

Granica

- Burbules, Nicolás (2008) Riesgos y promesas de las TIC en la educación, ¿Qué hemos aprendido de los últimos diez años? http://www.oei.es/pdfs/las tic aula agenda politica. pdf

- Cabero, J (2004) "Reflexiones sobre la brecha digital y la educación, en Soto, F. y Rodríguez, J (coords.) (2004)Tecnología, educación y diversidad: retos y realidades de la inclusión digital", Murcia, Consejería de Educación y Cultura. 23-42.

- Cabero, J. (2001) "La sociedad de la información y el conocimiento, transformaciones tecnológicas y sus repercusiones en la educación", en Blázquez, F. (coord.): Sociedad de la Información y Educación, Badajoz, Consejería de Educación, Ciencia y Tecnología, Badajoz, 63-90.

- Cabero, J. (2002) "Mitos de la sociedad de la información: sus impactos en la educación, en AGUIAR, M.V. (coords.): Cultura y educación en la sociedad de la información", A Coruña, Netbiblo, $17-38$

- Cabero, J. (2003) "Replanteando la Tecnología Educativa". En Comunicar, 21, páginas 23-30

- Cabero, J., Salinas, J., Duarte, A., Domingo, J., (2000) "Nuevas tecnologías aplicadas a la educación", Ed. Síntesis, Madrid.

- Cabero, J.; Córdoba, M. y Fernández, J.Ma (2007). „Las TICs para la igualdad. Nuevas tecnologías y atención a la diversidad". Sevilla, Eduforma.

- Camus, J. C. (2009)"Tienes 5 segundos" Copias digitales de este libro están disponibles en www.tienes5segundos.cl

- Casal, V. (2007)"Las tecnologías de la información y comunicación como herramientas para la inclusión escolar en situaciones educativas de riesgo." En http://www.quadernsdigitals.net/index.php?accionMenu=hemerotec a.VisualizaArticuloIU.visualiza\&articulo id $=10211$

- Center for Universarl Design de la Universidad de North Carolina http://www.ncsu.edu/ncsu/design/cud/about ud/udprinciples.htm

- Cole, M. y Engeström, Y. (2001) Enfoque histórico-cultural de la cognición distribuida. En Salomon, G. Cogniciones distribuidas. Amorrortu Editores. Buenos Aires.

- Colvin, C. y Mayer, R. (2008) Learning together virtually. En: ELearning and the Sciencie of Instruction: Proven Guidelines for Consumers and Designers of Multimedia Learning. San Francisco, CA: John Wiley \& Sons/Pfeiffer. 
- Coll, C. (2003) "Tecnologies de la informació i la comunicació i pràctiques educatives". En C. Coll (Coord.), Psicología de l'Educació. Edición en formato web. Barcelona: Universitat Oberta de Catalunya.

- Coll, C. y Martí, E. (2001) La educación escolar ante las nuevas tecnologías de la información y la comunicación. En: C. Coll, J. Palacios y A. Marchesi (Comps.), Desarrollo psicológico y educación. 2. Psicología de la educación escolar (pág. 623-651).

- Coll, C. y Monereo, C.(2008)"Psicología de la educación virtual", Madrid: Morata

- Díaz Barriga, F. (2005). "Principios de diseño instruccional de entornos de aprendizaje apoyados con TIC: un marco de referencia sociocultural y situado". Tecnología y Comunicación Educativas (41), 4-16, ILCE-UNESCO.

- Díaz Barriga, F. (2007). "La innovación en la enseñanza soportada en TIC. Una mirada al futuro desde las condiciones actuales". Ponencia presentada en la XXII Semana Monográfica de Educación, Fundación Santillana, Madrid, España, http://www.oei.es/tic/santillana/Barriga.pdf

- Díaz Barriga, F. y Morales Ramírez, L. (2009)" Aprendizaje colaborativo en entornos virtuales: un modelo de diseño instruccional para la formación profesional continua". Tecnología y Comunicación Educativas (47), 4-25, ILCE-UNESCO.

- Donath, J. (2003). "Identidad y engaño en la comunidad virtual". En: M. Smith y P. Kollock (Eds.). Comunidades en el ciberespacio (pp. 51-88). Barcelona: UOC.

- Drucker, P. (1994) "La sociedad post capitalista", New York, Harper Business

- Eisner, E (1995) "Educar la visión artística" Barcelona, Paidós Ibérica.

- Eisner, E (2002) "La escuela que necesitamos. Ensayos personales". Amorrortu. Buenos Aires.

- Etcheverría, Javier (2004) "Los señores del aire: Telépolis y el tercer entorno", Barcelona, Editorial Destino.

- Flavell, J. H. (1976). Metacognitive aspects of problem solving. In L. B. Resnick (Ed.), The nature of intelligence (pp. 231-235). Hillsdale, $\mathrm{NJ}$ : Erlbaum.

- García Aretio, Ruiz Corbella, M.; Domínguez Fajardo, D. (2007)"De la educación a distancia a la educación virtual". Barcelona: Ariel.

- Gardner, H. (1991). "The Unschooled Mind: How children think and how schools should teach". New York: Basic Books. 
- Gardner, H. (1993). "Multiple Intelligences: The theory in practice". New York: Basic Books.

- Gardner, H. (2006). "Multiple Intelligences: New Horizons". New York: Basic Books. Translated into: Romanian, Chinese.

- Gonnot, J. P. (2007) "Participatory dialogue. Towards a Stable, Safe and Just Society for All", New York, United Nations publication.

- González Perea, S (2008) "Guía de Accesibilidad a los Medios de Comunicación de Personas con Discapacidad Sensorial", Málaga.

- González, A (2008) "TICs en el proceso de articulación entre la escuela media y la universidad. Personajes Virtuales como herramientas de un entorno de aprendizaje multimedia". Tesis de Magister en Tecnología Informática Aplicada en Educación. Director: De Giusti Armando. CoDirector: Malbrán María del Carmen Facultad de Informática-Universidad Nacional de La Plata, Argentina.

- Guenaga, María Luz, Ander Barbier \& Andoni Eguíl Luz (2007), „La accesibilidad y las tecnologías en la información y la comunicación"en TRANS. REVISTA DE TRADUCTOLOGÍA 11, Universidad de Deusto.

- Herrera Batista, M. A. (2004) "Las Nuevas Tecnologías en el Aprendizaje Constructivo", en http://www.rieoei.org/deloslectores2.htm

- Hung, D. y Der-Thanq, Ch. (2001). Situated cognition, vygotskian thought and learning from communities of practice perspective: implications for the design of web-based e-learning. Education Media International. http://www.tandf.co.uk/journals/

- Hutchins, Edwin (1990) The Technology of Team Navigation. In Intellectual Teamwork: Social and Technological Foundations of Cooperative Work. J. Galegher, R. E. Kraut and C. Egido, ed. Pp. 22-51. Hillsdale, NJ: Erlbaum

- Hutchins, Edwin (1995). Cognition in the Wild. MIT Press.

- ITU (2010) World Telecommunication/ICT Indicators Database 2010, 14 th Edition

- Jiménez Lara, A. (2011) "El estado actual de la accesibilidad de las tecnologías de la información y la comunicación (TIC); Observatorio Fundación Vodafone-CERMI. España.

- Johnson-Laird, P (1995) "Metal Models". EE.UU. Library of Congress Cataloging in Publication Data.

- Katz, J y Hilbert, M, (2003) "Los caminos hacia una sociedad de la información", en América Latina y el Caribe; CEPAL n 72

- Krug, S. (2006) "No me hagas pensar", segunda edición, España, Pearson Prentice Hall. 
- Lave, Jean y Wenger Etienne. (1991) "Situated Learning. Legitimate peripheral participation". U.K.Cambridge University Press.

- Luckasson, R., Borthwick-Duffy, S, Buntix, W. H. E, Culter, D., Craig, E., Reeve, A., (2002). "Mental retardation: Definition, classification, and Systems of supports (9th Ed.) "Washington, DC: American Association on Mental Retardation.

- Mace, R. FAIA (2002) at "Designing for the 21st Century: An International Conference on Universal Design," New York, Hofstra University, Hempstead.

- Majó, J. y Marqués, P. (2002): "La revolución educativa en la era de Internet", Barcelona, Praxis.

- Malbrán M del C. (2005) Madres inclusivas. Concurso Provincial "La situación de la mujer en la provincia de Buenos Aires, 19952005"Dirección Provincial de Igualdad de Oportunidades. Secretaría de Derechos Humanos de la Pcia. Bs. As.

- Marchesi, A. y Martin, E. (1998): "Calidad de la enseñanza en tiempos de cambios", Madrid, Alianza.

- Martí, E. (1992) Aprender con ordenadores en la escuela. Barcelona: Horsori / ICE de la Universidad de Barcelona.

- Martí, E. (2003) Representar el mundo externamente. Madrid: Antonio Machado.

- Martín Ortega, E. y Marchesi Ullastres, A. (2006) La Integración de TICs en los Sistemas Educativos. Propuestas de introducción en el currículo de las competencias relacionadas con las TIC. IIPEUNESCO. Buenos Aires.

- Martínez, F. y Solano, I (2003) "El proceso comunicativo en situaciones virtuales". En Martínez, F. (coord.). Redes de comunicación en la enseñanza. Barcelona. Paidós. 13-30.

- Mon, F (2000) En: HAVLIK, Jarmila M. "Informática y discapacidad: fundamentos y aplicaciones". Buenos Aires: Ediciones Novedades Educativas, 2000, p. 61-79.

- Mon, Fabiana (2006) „Discapacidad visual: aporte interdisciplinario para el trabajo con la ceguera y la baja visión". Buenos Aires, Novedades Educativas

- Negre Bennasar, F. (2011) Del conmutador a la interacción cerebro-máquina: Aproximación a un modelo de desarrollo de sistemas de acceso al ordenador para personas con discapacidad Universitat de les Illes Balears en: http://congreso.tecnoneet.org/actas2010/docs/xnegre.pdf

- Nielsen, J. (1993) Usability Engineering, San Diego, USA; Academic Press. 
- Nirje, B. (1970) "The Normalization Principle. Implications and Comments". Brit. M. Mental Retardation, 13, 24-27

- Norman, Donald A. (1988), "The Design of Everyday Things", New York, Currency/Doubleday.

- $\quad$ Norman, D. ( 1994) "Things That Make Us Smart: Defending Human Attributes In The Age Of The Machine" New York, Basics Books

- Norman, D. (1983) "Some observations on mental models". In Gentner, D y Stevens, A. L. (Eds.) Mental Models. Hillsdale, NJ. Lawrence Erlbaum Associates.

- Paivio, A. (1969). "Mental Imagery in associative learning and memory" Psychological Review, 76(3), 241-263.

- Paivio, A. (1971). "Imagery and verbal processes". New York: Holt, Rinehart, and Winston.

- Paivio, A. (1986). "Mental representations: a dual coding approach" Oxford. England: Oxford University Press.

- Pavón, F y Casanova, J, (2006) "Telefonía móvil y personas mayores: la accesibilidad como derecho", Revista Latinoamericana de tecnología educativa, 5 (2) 385,395.

- Pea, R. (2001) "Prácticas de inteligencia distribuída y diseños para la educación". En Salomon, G. Cogniciones distribuidas. Amorrortu Editores. Buenos Aires.

- Perkins, D (2001) "La persona - más: una visión distribuida del pensamiento y el aprendizaje". En Salomon, G. Cogniciones distribuidas. Amorrortu Editores. Buenos Aires.

- Reigeluth, Ch. (1996): "A new paradigm of ISD", Educational Technology, 36, 3, 13-20

- Rifkin, J. (2000)" La Era del Acceso" España, Paidós Ibérica.

- Robert L Schalock; James F Gardner; Valerie J Bradley (2007) " Quality of life for people with intellectual and other developmental disabilities : applications across individuals, organizations, communities, and systems" Washington, D.C. American Association on Intellectual and Developmental Disabilities

- Rogoff, B. (2003) "The cultural Nature of Human Development". New York, Oxford University Press.

- Rogoff, B. y Lacasa, P. (1993) "Aprendices del pensamiento: el desarrollo cognitivo en el contexto social". Barcelona, Paidós.

- Roig Vila, R. (2007). Las Tecnologías de la Información y la Comunicación (TIC) como recurso en la atención a las necesidades especiales. En A. Lledó Carreres, La discapacidad 
auditiva, un modelo de educación inclusiva (183-190). Barcelona: Edebé.

- Royo, J. (2004) "Diseño Digital". Madrid. Editorial Paidós.

- Salomón G., Perkins, D. y Globerson, T, (1992) "Coparticipando en el conocimiento: la ampliación de la inteligencia humana con las tecnologías inteligentes. En: Comunicación, Lenguaje y Educación, CL\&E, No 13; 6-22

- Salomon, G. (2001). "Technology and education in the age of information". Zmora-Bitan (Hebrew).

- Sánchez Montoya, R. (2002) "Ordenador y discapacidad" C.E.PE (Ciencias de la Educación Preescolar y Especial) Madrid. España.

- Sánchez Montoya, R. (2006). Capacidades visibles, tecnologías invisibles: Perspectivas y estudio de casos. En RODRÍGUEZ, J., MONTOYA, R. Y SOTO, F.J. (coords.): Las tecnologías en la escuela inclusiva: nuevos escenarios, nuevas oportunidades. Murcia: Consejería de Educación y Cultura

- Sánchez Montoya. (2002) "Ordenador y discapacidad" C.E.PE (Ciencias de la Educación Preescolar y Especial) Madrid. España.

- Sancho Gil, Juana María (2002) Las tecnologías de la información y la comunicación en la enseñanza superior: una aproximación compleja. Revista de educación y pedagogía, vol. 14, no 33, pág. 29 a 48

- Schalock, R y Verdugo, M (2002) „Handbook on quality of life for human service practitioners". Washintogn, D.C. American Association on Mental Retardation.

- Schalock, R.L. (1996). "The quality of children's lives. In A.H. Fine y N.M. Fine (Eds.), Therapeutic recreation for exceptional children. Let me in, I want to play". Second edition. Illinois: Charles C. Thomas.

- Schalock, R. (1997) "Quality of Life, vol. II Application to persons with disabilities". Washington, D.C, American Association on Mental Retardation

- Siles Rojas, C. y Reyes Rebollo, M. (2001) La formación del profesorado en nuevas tecnologías y medios de comunicación como recursos de apoyo para el aprendizaje de las personas con necesidades educativas especiales. Comunicación en Las nuevas tecnologías aplicadas a la educación en el siglo XXI. En http://tecnologiaedu.us.es/ticsxxi/comunic/csr-mmrr2.htm.

- Skinner, B.F. Cumulative Record: A Selection of Papers, 1959, 1961, 1972 and 1999 as Cumulative Record: Definitive Edition.

- Soto Pérez, F.J. y Rodríguez Vázquez, J. (Coords.) (2004). Tecnología. Educación y Diversidad: Retos y Realidades de la 
Inclusión Digital. Murcia: Consejería de Educación y Cultura.

Tecnoneet.

- Sternberg, R. (1990) "Handbook of Human Intelligence".

Cambridge. Cambridge University Press.

- Sternberg, R. J. (2003). Cognitive theory (3rd Ed.). Belmont, CA: Thomson Wadsworth.

- Sternberg, R. y Gringorenko, E. (2003a) "Evaluación dinámica. Naturaleza y mediación del potencial de aprendizaje". Barcelona, Ediciones Paidós Ibérica

- Sternberg, R.; Gringorenko, E. y Kaufman, J (2009) "The Essential Sternberg". New York, Springer Publishing Company.

- Sternberg, Robert J. (2006). Cognitive psychology fourth edition. Thomson Wadsworth. pp. 234-36.

- Sternberg. R y Kaufman, S (2011) "The Cambridge Handbook of Intelligence". Cambridge. Cambridge University Press.

- Tezanos, J.F. (2001): "La sociedad dividida. Estructuras de clases y desigualdades en la sociedad tecnológica", Madrid, Biblioteca Nueva

- The European Commission (2008) An Essential Guide to the Institution, the Procedure and the Policies. London. Kogan Page Publishers.

- Van Dijk, T. (1995) "On macroestructures, mental models and other inventions: a brief personal history of the Kintsch-Van Dijk theory. En F. Healy, S. Kossllyn y Shiffrin (eds.) Essays in honor of William K. Estes. Hillsdales, N. Erlbaum.

- Vigotsky, L. (1991) "Obras escogidas". Madrid, Visor

- Vigotsky, L. (1995) "Pensamiento y lenguaje". Barcelona, Paidós. (Primera edición 1934)

- Vigotsky, L. (1997) "La imaginación y el arte en la infancia: ensayo psicológico." México, Fontamara.

- Watzlawick, S., J.H. Beavin y D.D. Jackson (1990), "Menschliche Kommunikation: Formen, Störungen, Paradoxien", Bern Auflage y otros (comps.).

- Wolfensberger, W. (1972). "Normalization: the principles of normalization in human services". Toronto: National Institute of Mental Retardation. 


\section{Anexo I}

Se presentan a continuación los cuestionarios correspondientes a la encuesta y entrevista realizadas.

\section{Entrevista usuarios con limitación en la visión}

Estamos realizando una entrevista para valorar la usabilidad de los lectores de pantalla en distintos accesos a la Web.

Le agradecemos nos responda lo más sinceramente posible, pues su opinión es de importancia para nuestro trabajo.

Nombre:

Edad:

Sexo:

Estudios cursados:

1. ¿Podría mencionarme cuáles son las tareas que realiza utilizando la computadora?

2. ¿Emplea lectores de pantalla para acceder a la información de su computadora? ¿Cuál/es?

3. ¿Con qué frecuencia? Marque la o las opciones que correspondan:

- En todo momento

- De modo frecuente

- Ocasionalmente, para mejorar la lectura de algunos sitios o programas

- Ocasionalmente, para evaluar los niveles de accesibilidad de páginas que me interesan 
4. ¿Cuál es el lector de pantalla que comúnmente utiliza?

5. ¿Por qué lo eligió?

6. ¿Cuáles son los temas que le interesan al navegar por Internet?

7. ¿Tiene páginas o sitios que prefiere consultar? ¿Cuáles? ¿Por qué motivo los prefiere?

8. Describa el modo en que se presenta la información en estos sitios (imágenes, textos, planillas, videos, etc.)

9. ¿Cuáles son las facilidades, ventajas, que encuentra en los sitios o páginas que prefiere visitar?

10. ¿Cuáles son las dificultades, obstáculos que encuentra en los sitios que suele navegar por Internet?

11. Describa un ejemplo breve de la información difícil de acceder /entender.

12. ¿Qué sugerencias puede hacer para solucionar, mejorar estos inconvenientes?

13. ¿Hay algún indicador que usted consulte/ubique al leer las pantallas, para conocer el grado de facilidad de navegación y accesibilidad? 


\section{Usabilidad del lector de pantallas en páginas Web}

Estamos realizando una encuesta para valorar la usabilidad de los lectores de pantalla en distintos accesos a la Web.

Le agradecemos nos responda lo más sinceramente posible, pues su opinión es de importancia para nuestro trabajo.

Por favor, marque la respuesta elegida.

Datos Personales

Edad:

Estudios cursados:

Sexo:

1. ¿Utiliza Internet?

- $\quad \mathrm{Si}$

- No

2. Si responde afirmativamente, ¿cuánto la utiliza?

- diariamente

- $\quad$ semanalmente

- $\quad$ alguna vez al mes

3. Utiliza Internet principalmente para:

- $\quad$ Estudiar

- $\quad$ Comunicarse (correo electrónico, chat, redes sociales, etc.)

- $\quad$ Entretenerse (escuchar música, ver películas, etc.)

- Otros usos:

4. ¿Qué navegador/es utiliza más?

- Opera

- Internet Explorer

- Mozilla-Firefox

- Google-Chrome

- $\quad$ Otro (indicar cuál) 
5. ¿Cuándo utiliza el lector de pantalla?

- $\quad$ Siempre, por mi dificultad en la visión

- $\quad$ A veces, por mi dificultad en la visión

- $\quad$ A veces, aún sin tener dificultad en la visión

- Ocasionalmente, para evaluar la accesibilidad de alguna página

6. ¿Cuál es el lector de pantalla que generalmente utiliza?

- Window-Eyes

- NVDA

- JAWS

- $\quad$ Otros (indicar cuál)

7. ¿Cuál es el motivo de la elección del lector de pantalla?

8. ¿ ¿Cuáles son las páginas que más frecuenta?

9. ¿Por qué las elige?

10. ¿Cuál de estas acciones realiza al acceder a dichas páginas?

- $\quad$ Lee a través de la página de modo general

- $\quad$ Navega o escucha a través de los links de la página

- $\quad$ Utiliza el buscador de la página para encontrar lo que desea

- $\quad$ Utiliza el mapa del sitio o el índice

- $\quad$ Otros (indicar cuáles)

11. ¿Qué facilidades o ventajas encuentra en las páginas elegidas?

12. ¿Qué dificultades o desventajas encuentra en las mismas páginas?

13. ¿Hay algo que quiera sugerir con respecto a lo consultado? 


\section{Anexo II}

Se expondrá el documento redactado como resultado de la lectura y análisis de los datos recogidos en el trabajo de campo de la presente tesis. 